\title{
Pollen morphology of some species of the genus Quercus L. (Fagaceae) in the Southern Caucasus and adjacent areas
}

\author{
ALLA HAYRAPETYAN ${ }^{1}$ and ANGELA A. BRUCH ${ }^{2 *}$ \\ ${ }^{1}$ Institute of Botany after A. Takhtajan, National Academy of Sciences of the Republic of Armenia, Yerevan, \\ Armenia; e-mail: alla.hayrapetyan.63@gmail.com \\ ${ }^{2}$ ROCEEH Research Centre 'The role of culture in early expansions of humans' of the Heidelberg Academy \\ of Sciences, Senckenberg Research Institute, Senckenberganlage 25, 60325 Frankfurt am Main, Germany; \\ e-mail: abruch@senckenberg.de
}

Received 12 August 2019; accepted for publication 25 November 2019

\begin{abstract}
The palynomorphology of 19 modern species of the genus Quercus L. native to Armenia and adjacent regions, including the Caucasus and Transcaucasia, the Mediterranean region (especially Turkey), as well as Iran, Iraq and Afghanistan, was studied using light microscopy (LM) and scanning electron microscopy (SEM). The work revealed two main types of apertures (3-zonocolpate, 3-zonocolp-porate) as well as six morphological types of pollen based on three main types of exine ornamentation (tuberculate, verrucate, rugulate). We suggest that two main groups of exine ornamentation developed from a common initial type. The first group covers all species of the subgenus Quercus and also Q. suber and Q. alnifolia of the subgenus Heterobalanus. The second group is limited to the morphological type $Q$. ilex (species Q. ilex, Q. coccifera, subgenus Heterobalanus).

On the other hand, the presence of widespread interspecific and introgressive hybridization within the genus Quercus indicates an ongoing process of speciation. This also has an effect on pollen features, which are very similar in a number of species but also vary in individual samples even within the same species. The morphological uniformity of the pollen surface (especially for the subgenus Quercus), the presence of islets of secondary sporopollenin on the surface of pollen grains, as well as orbicules in anthers, do not indicate general primitiveness of representatives of this genus but most likely denote a relatively high degree of speciation activity within this group.
\end{abstract}

KEYWORDS: Exine ornamentation, LM, SEM, interspecific uniformity, intraspecific variability

\section{INTRODUCTION}

The genus Quercus is well represented in modern and fossil pollen archives documented since the Eocene (e.g. Denk et al., 2012; Grímsson et al., 2015, 2016; Barrón et al., 2017). Fossil pollen records of the genus play an important role in reconstructing environmental changes and serve as vital indicators of past climate and vegetation, especially in Eurasian mid-latitudes (e.g. Tzedakis et al., 2006; Litt et al., 2014; Sadori et al., 2016; Barrón et al., 2017). Molecular and fossil evidence

\footnotetext{
Corresponding author
}

suggests that the genus evolved and started to radiate from the early Eocene on with the divergence of the 'Old World' clade (Groups Cyclobalanopsis, Ilex, Cerris) and the 'New World' clade (Groups Lobatae, Protobalanus, Quercus), while a second divergence developed during the middle Eocene within the latter, between the red oak lineage (Group Lobatae) and the golden cup-white oak lineage (Groups Protobalanus, Quercus) (Hubert et al., 2014; Grímsson et al., 2016).

Today the genus Quercus includes 400-500 species (Menitsky, 1984, 2005) of deciduous or 
evergreen trees and shrubs that grow in temperate to tropical zones of the Northern Hemisphere (Europe, Asia, America). In Eurasia the northern limit of distribution reaches $62-63^{\circ} \mathrm{N}$ and the southern limits extend a few degrees south of the Equator (Menitsky, 1984, 2005). In Europe oaks grow from Scandinavia, where only $Q$. robur and $Q$. petraea occur, to the Mediterranean region, and extend into Northern Africa (e.g. Q. suber, Q. ilex). Most of the European species ( 20) grow in the Mediterranean region and in some areas of SW Asia (Schwarz, 1964).

The modern woody vegetation of the Caucasus is quite rich in species of this genus; they vary in their preferences for growing conditions. For example, Q. macranthera Fisch. et C.A.Mey. ex Hohen. occurs mainly in broadleaved forests at $1300-2700 \mathrm{~m}$ a.s.l.; Q. araxina (Trautv.) Grossh. (for synonymy see Tab. 1) is characteristic of arid woodlands (600-1000 m a.s.l.); Quercus robur subsp. pedunculiflora (K.Koch) Menitsky grows in deciduous riparian forests and on the banks of rivers and streams at 500-800 m a.s.l. (Mulkidzhanyan, 1962).

Takhtajan (1966) considered the suborder Hamamelidanae, which includes the family Fagaceae, as a very ancient group and at the same time one of the main branches of the family tree of the Dicotyledonae. Flower specialization here is associated with the transition from entomophily to anemophily, due to the adaptation of ancestral forms to the general climatic trend towards cooler and drier conditions, being especially affected by increased seasonality and thus dryness during the flowering period (Menitsky, 1984). According to Greenfeld (1962), anemophily is an adaptive strategy of pollination in the Amentiferae (which includes the family Fagaceae). Anemophily can be viewed as a progressive trait which ensured this group the leading position in the composition of temperate floras of the Northern Hemisphere. Later, Takhtajan (1997) transferred the family Fagaceae to the suborder Faganae, which emerged directly from Hamamelidanae and is characterized by the presence of strongly reduced flowers as one of the main diagnostic features.

Menitsky (1984) divided the Fagaceae into two subfamilies, Fagoideae and Castaneoideae (with two tribes in each subfamily), based on shape of fruits, type of seed germination, chemical composition of seeds, and other traits. Takhtajan (2009) distinguished four subfamilies as a part of the Fagaceae: Quercoideae (1 genus),
Trigonobalanoideae (3 genera), Castanoideae (4 genera) and Fagoideae (1 genus). Except for Notholithocarpus, Grímsson et al. (2016) give exactly the same division of the family.

The systematic position of the genus Quercus is still debated. In his earlier works, devoted to the system and phylogeny of flowering plants, Takhtajan $(1966,1987)$ noted that the most primitive genera within the family are Nothofagus and Fagus, which was in accordance with Praglowski (1982); Quercus as part of subfamily Quercoideae was deemed the most advanced genus. Later, however, based on new published data (e.g. Wang and Chang, 1991; Hill and Read, 1991; Hill and Jordan, 1993; Kubitzki, 1993; Jones, 1986; Wang et al., 2000; Manos et al., 2001; Cao and Zhou, 2002), Takhtajan (1997, 2009) allocated the genus Nothofagus to the separate family Nothofagaceae and the subfamily Quercoideae with the single genus Quercus in an initial position within the family Fagaceae; then, the genus Fagus in the subfamily Fagoideae was deemed the most advanced one. Much earlier, Kuprianova (1965), describing the pollen of wind-pollinated plants, already considered the Quercus pollen type with tuberculate sculpture and poorly visible pores to be the most primitive type within Fagaceae, while pollen grains of Fagus have clearly expressed endoapertures (ora) in the colpi and therefore can be seen as more developed.

According to Menitsky (1980, 1982, 1984), the genus Quercus is divided into four subgenera:

1. Subgenus Cyclobalanopsis (cycle-cup oak), considered one of the oldest in the genus. Its species derived from the group Cyclobalanus of the genus Lithocarpus Blume. Representatives of this group of evergreen oaks grow exclusively in East and South-East Asia (from the western Himalayas to Japan, from central China to the islands of Sumatra and Java).

2. Subgenus Erythrobalanus (red oaks), with a distribution area limited to the Americas, also a very ancient group in the genus. Nevertheless, it is a very competitive group of deciduous and evergreen oaks, which often successfully replace not only other oaks but also conifers.

3. Subgenus Heterobalanus, a group of evergreen sclerophyllous oaks that grow in temperate (rarely subtropical) zones of the Mediterranean mountains, South-West, East and South-East Asia (primarily in the mountains of East Asia and the Himalayas). 


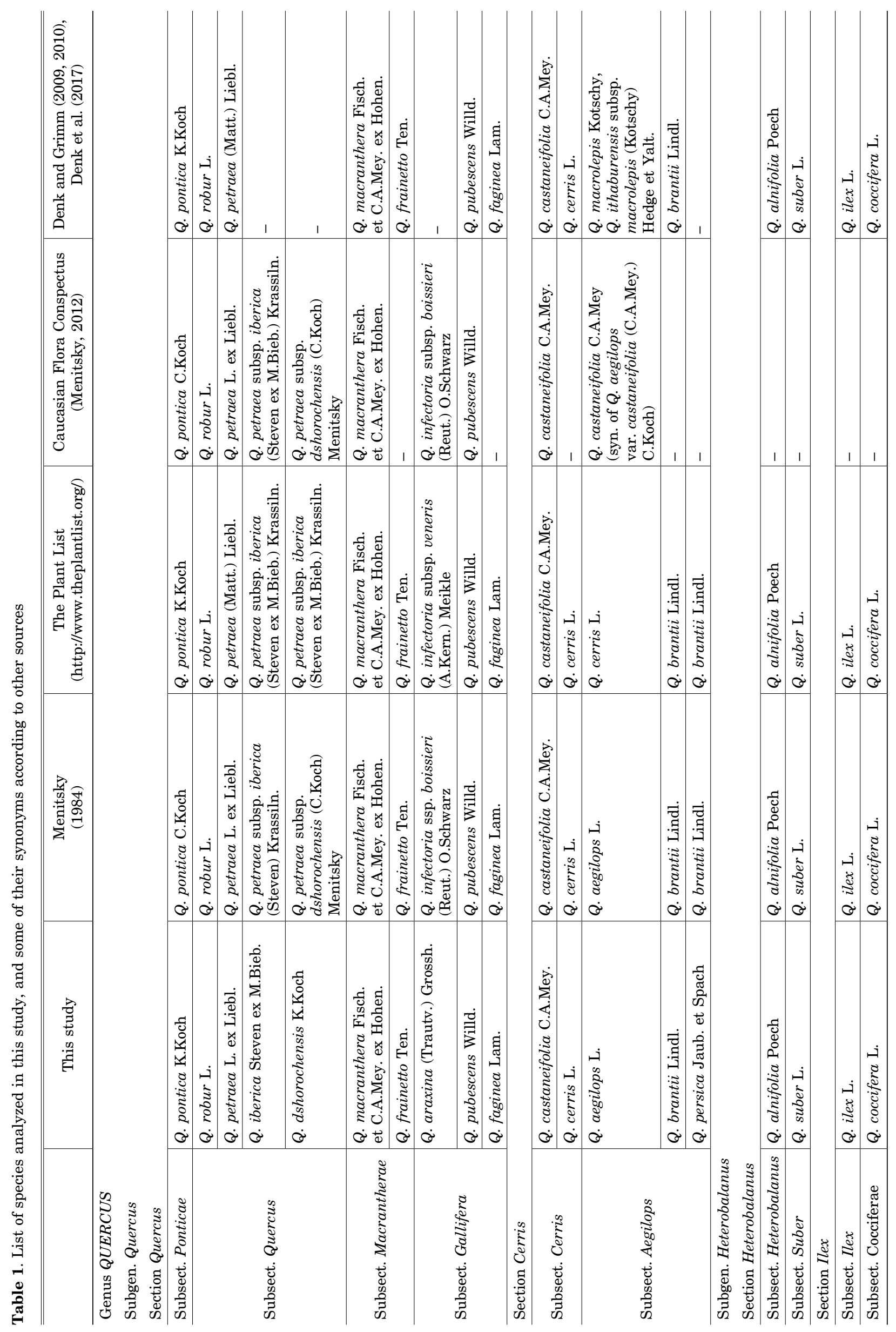


4. Subgenus Quercus (white oaks), a group of deciduous oaks growing in temperate to cooler regions of Eurasia and North America. They are important forest-generating elements or co-dominants in mixed deciduous forests. According to Menitsky $(1980,1984)$ this group of species is the youngest and the evolutionarily more advanced one in the genus.

Interesting and multifaceted investigations on various aspects of the genus Quercus were carried out by Denk and co-authors (Denk and Grimm, 2009, 2010; Denk et al., 2012; Denk and Tekleva, 2014; Denk et al., 2017). All 33 accepted species of the genus Quercus studied by Denk and Grimm (2009, 2010) from Western Eurasia (of which about one third is covered by our study) are combined into three morphologically distinct groups (Denk and Grimm, 2010: table 3) which are almost completely in accordance with the Menitsky system (1984). These are Group Ilex (syn. Q. subg. Heterobalanus sensu Menitsky, 1984), Group Cerris (syn. Q. subg. Quercus, sect. Cerris sensu Menitsky, 1984) and Group Quercus (syn. Q. subg. Quercus, sect. Quercus sensu Menitsky, 1984) (Denk and Grimm, 2010: table 3). Later Denk et al. (2017: 16) stated that 'Menitsky's account is the only morphology-based system that correctly identified the natural groups of Eurasian oaks confirmed later by palynological and molecular data'.

Nevertheless, we would like to note that the question of the monophyleticity of the genus Quercus, including the status of the subgenus Cyclobalanopsis (Oersted) C.K. Schneider in the genus Quercus, is still a matter of debate and was discussed in detail by Xing et al. (2013). And while Grímsson et al. (2016) characterize the genus Quercus as 'probably monophyletic' (p. 250), according to Xiang et al. (2014) '...29 of the 32 genera of Fagales (except Castanopsis, Ostrya and Quercus) were monophyletic...' (p. 104).

According to our preliminary data, as well as the available literature, the main diagnostic features of pollen of the genus Quercus can be considered to be the overall size of pollen grains, exine thickness and especially the type of exine ornamentation (e.g. Samoilovich, 1950; Monoszon, 1954, 1961; Avetisyan and Manukyan, 1962; Kuprianova, 1965; Kuprianova and Alyoshina, 1972; Smit, 1973; Solomon, 1983a,b; Van Benthem et al., 1984; Médus and Gonzalez Flores, 1984; Valdes et al., 1987; Nakagawa et al., 1996; Liu et al., 2007; Denk and Grimm, 2009; Hayrapetyan, 2013).

The study of modern pollen of the genus Quercus started at the beginning of the 20th century with the works of Docturowsky and Kudriaschow (1923), Erdtman (1923), Meinke (1927) and others. Wodehouse (1935) described pollen of eight species of the genus, characterizing them as 3(sometimes 4 or 6)-colpate with 'warty-granular' exine ornamentation. A year later, Wodehouse (1936) suggested the presence of pores in the colpi, supposing that the most distinctive feature of pollen grains of Quercus is their hyaline wedge-shaped plugs underlying the colpi. Thirty years later, those thickenings of the intine outer layer (named hyaline) were described by Kuprianova (1965) as 'oncus', following Hyde's (1955) terminology. According to Kuprianova (1965), precisely the presence of such onci serves as a proof of functioning pores.

Another distinctive feature of pollen of many representatives of the genus Quercus is the presence of a geniculum. Naryshkina (2013) and Tekleva and Polevova (2014), describing pollen of the genus Quercus as colporate, tried to link the presence of a geniculum with the presence of an endoaperture (os). However, Quercus is not defined as colp-orate, but colp-porate pollen grains and furthermore the presence of genicula in general are not necessarily associated with a specific type of aperture, because they can be observed for pollen grains of species from different genera as well with 3-zonocolpporate as with 3-zonocolp-orate apertures (see Morphological terminology section herein).

Until the 1970s, palynomorphological investigations of the genus were carried out mainly at the level of light microscopy (e.g. Samoilovich, 1950; Erdtman, 1952; Monoszon, 1954, 1961; Kuprianova, 1965; Kuprianova and Alyoshina, 1972). An exception is Mühlenthaler (1955), who studied the surface as well as the exine structure of pollen grains of $Q$. robur using electron microscopy.

On the level of LM, the exine ornamentation of pollen grains of the genus Quercus is characterized by some authors as 'granulate' (Wodehouse, 1935; Shtepa, 1942; Samoilovich, 1950; Monoszon, 1954, 1961) or 'tuberculate' (Kuprianova, 1965; Kuprianova and Alyoshina, 1972). The latter term is sometimes used by some modern authors as well (e.g. Tekleva and Polevova, 2014). However, the vast majority of researchers use the term 'verrucate', and in most cases 
such a characterization of exine ornamentation refers to pollen of the subgenus Quercus. In our opinion, the parallel use of these terms is associated with the significant variability of sculptural elements in size, shape, density, and the presence or absence of supratectal elements, in pollen even from a single flower.

The work of Smit (1973), who used SEM to investigate the pollen morphology of some Eurasian species of the genus Quercus, is one of the basic studies of Quercus pollen. Using some pollen characteristics (exine ornamentation, colpus membrane, aperture), the author distinguished three major pollen types. These types correspond to the three subgenera defined by Schwarz (1936b-1939, 1964): Quercus robur/petraea type, Q. ilex/coccifera type and $Q$. suber type.

In a study of the pollen morphology of white (subgenus Quercus) and red (subgenus Erythrobalanus) oaks in eastern North America, Solomon (1983a,b) noted that the pollen type of the red oak derived directly from the white oak type. This assumption follows Trelease's opinion (1924) that red oaks are phylogenetically advanced as compared to white oaks, in contrast to Menitsky (1984), who affirmed that Erythrobalanus is a very ancient group in the genus.

In the literature since the middle of the 20th century on the palynology of the genus Quercus, the main epithets describing the pollen characteristics of this genus are 'considerable variability' and 'uniformity' (e.g. Shtepa, 1942; Samoilovich, 1950; Monoszon, 1954, 1961; Van Benthem et al., 1984; Médus and Gonzalez Flores, 1984; Liu et al., 2007). The major diagnostic features suggested for characterizing the pollen of certain species of this genus are the shape and size of pollen grains, exine thickness, the type of apertures, exine ornamentation, the number of sculptural elements per unit area, and the presence or absence of a geniculum, among others. However, all these features are later challenged by further studies which stress the significant variability of each of them in most cases even within one sample, and therefore cannot be considered diagnostic.

For example, Colombo et al. (1983) used data from scanning and transmission electron microscopy to confirm Smit (1973). They follow his separation of three main pollen groups according to the type of exine ornamentation, and additionally consider differences in exine thickness as diagnostic. However, in the end the authors conclude that the best diagnostic features for distinguishing between species are the shape and size of pollen grains, thus returning to the opinion of Shtepa (1942), Monoszon (1954) and others.

The paradox of pollen of the genus Quercus is that intraspecific variability within this genus is greater than interspecific variability (Pilcher, 1968; Blanco et al., 1996; Dupont and Dupont, 1972; Olsson, 1975). This variability was also shown by Van Benthem at al. (1984) in a comparative palynomorphological analysis of three closely related and well-studied species: Q. robur, Q. petraea and Q. pubescens. Moreover, this phenomenon is described by different authors not only for individual species but also for infrageneric groups (Solomon, 1983a,b; Makino et al., 2009; Denk and Tekleva, 2014). For example, Panahi et al. (2012, referring to Denk and Grimm, 2009) stressed that variability in Group Cerris is higher within than between species. For Western Eurasian members of the genus Quercus this is also confirmed by data from molecular phylogenetic studies by Denk and Grimm (2010: 357), who state that in most cases individuals of the same species were not markedly closer to each other than to other white oaks'.

Our study provides a detailed analysis of the pollen morphology of 19 recent species of the genus Quercus of Armenia and adjacent regions including the Caucasus and Transcaucasia, the Mediterranean region (especially Turkey), as well as Iran, Iraq and Afghanistan. The vast majority of the investigated species belong to subgenus Quercus (exclusively deciduous trees and shrubs from warm temperate and cold temperate regions of Eurasia and North America), while only four species refer to the subgenus Heterobalanus (sclerophyllous evergreen trees and shrubs restricted mainly to warm temperate regions).

In combination with published information, our comparative palynomorphological analysis of those species allowed an evaluation at different taxonomic ranks (within subgenera, sections and subsections).

\section{MATERIAL AND METHODS}

The species covered in our investigations belong to all sections and subsections of the subgenera Quercus and Heterobalanus (according to Menitsky, 1984, with 
additions from Grossheim, 1949; Mulkidzhanyan, 1962; Czerepanov, 1995). The list of species analysed in this study (Tab.1) includes detailed information on synonymies according to some different sources.

Pollen material was gathered from the herbaria of the Institute of Botany after A. Takhtajan of the National Academy of Sciences of Armenia in Yerevan (ERE), the Senckenberg Research Institute and Natural History Museum in Frankfurt (FR) and the State Museum of Natural History in Stuttgart (STU). The information given from the original herbarium vouchers is slightly edited, in the original language as labelled, and with English translation where necessary (Tab. 2). Collection information for the single specimens studied is listed in the section on specimens investigated.

The descriptions of pollen grains by light microscopy (LM) for each investigated species are based on acetolyzed material (Avetisyan, 1950) and also on grains stained with basic fuchsine (Smolyaninova and Golubkova, 1950). The details of exine structure and ornamentation, as well as the type of aperture, were studied from acetolyzed pollen grains. Pollen grain shape and size, and also aperture structure, were studied from non-acetolyzed stained pollen grains. The latter is crucial in the case of Quercus because it allows identification of onci beneath the apertures, since after acetolysis the intine is destroyed along with the protoplast (cytoplasm). Also, staining supports optical differentiation between exine layers, as the endexine is only very slightly or nearly not stained by basic fuchsine. Ten pollen grains were examined and measured for each investigated specimen (Tab. 2). For SEM, non-acetolyzed dry pollen grains were placed in a drop of alcohol and then mounted on aluminium stubs and sputter-coated with gold.

The specimens were examined and photographed under LM at the Institute of Botany after A. Takhtajan (Yerevan, Armenia), while SEM and additional LM studies were carried out at the Senckenberg Research Institute (Frankfurt, Germany). For LM investigations we used Olympus and PZO Warszawa light microscopes, and for SEM a Jeol JSM-6490 scanning electron microscope was run at $20 \mathrm{kV}$.

\section{MORPHOLOGICAL TERMINOLOGY}

The morphological terminology used in our study mainly follows Erdtman (1952), Kuprianova and Alyoshina (1972), Punt et al. (2007) and Hesse et al. (2009). However, although the terminological glossaries of Punt et al. (2007) and Hesse et al. (2009) are extremely informative and very convenient in most cases, some terms need further clarification.

The very easily accessible glossary of Punt et al. (2007) is nevertheless merely a collection of terms compiled by the authors from a wide variety of published sources. Concerning apertures, several completely different terms denoting the same element are listed. For example, the term 'colpus' is used to denote both the ecto- and endoaperture, taking into account only the shape of the aperture. Furthermore, Punt et al. (2007) gives several synonyms of the term 'endoaperture', including 'os (ora)', 'endocingulum', 'transversal furrow', etc., not explaining how to correctly combine them to describe a compound aperture.
In the excellently illustrated glossary of Hesse et al. (2009), the term 'colporus (colporate)' is described as a 'combination of porus and colpus' (Hesse et al., 2009: 17), while 'porus' is described as a 'more or less circular aperture' (Hesse et al., 2009: 235). At the same time the authors define 'colporate - pollen grain with colpori' and 'colporus (lat., pl. colpori) - compound aperture composed of a colpus (ektoaperture) combined with an endoaperture of variable size and shape' (Hesse et al., 2009: 228), where 'endoaperture is the inner part of a compound aperture' (Hesse et al., 2009: 229). As an example for the term 'colporoidate' (but not colporate), two different pollen types were given: colp-porate pollen of a species of the genus Quercus (as an example in the description of this term) and a micrograph of the colporate pollen of Eucommia sp. (Eucommiaceae fossil) (Hesse et al., 2009: 228) (using LM, since an os can be only detected using LM, but not with SEM). The term 'os' is not explained in the glossary.

However, in our opinion the nature of the origin of a morphological feature has to be considered first. Colpi are ectoapertures and a result of thinning or absence of the upper layers of the exine. Ora are endoapertures, which arose as a result of thinning or the complete absence of the inner layers of the exine. Besides, ora can have very different shapes (as also noted by Hesse et al., 2009: 129): rounded, elongated, or even forming a continuous ring in the equatorial region ('endocingulum' according to Punt et al., 2007).

Differences between the components of complex apertures (colpus, pore, os) also are manifested primarily in the functions they perform. The basic functional purpose of pores is known to be as the site for the exit of the pollen tube, while colpi, in addition to their harmomegate function, sometimes also provide protection for the most delicate areas of the pollen grains (HeslopHarrison, 1979). On the other hand, Blackmore and Barnes (1986: 145) suggested that 'endoapertures (i.e. ora) are more directly associated with harmomegathy and the provision of pathways for the transfer of water and other substances between the pollen cytoplasm than with germination and the exit of the pollen tube'.

Therefore, to describe the compound apertures in the most accurate and informative way, we chose to clearly distinguish between apertures that consist of colpus and pore (colp-porate) versus colpus and os (colporate). We avoid merging these two terms (i.e. colporate) to make it unambiguously apparent if the second constituent element of the aperture is a pore or an os.

Some of the terms frequently used in this study are defined as follows.

Colpus (colpi - pl.): more or less elongated, membrane-covered aperture with a length and breadth ratio greater than 2, formed mainly as a result of thinning or absence of the upper sculptural layers of the exine (Erdtman, 1943; Kuprianova and Alyoshina, 1967; Punt et al., 2007). Thus, colpi are apertures in the ectexine, or ectoapertures (Avetisyan and Hayrapetyan, 2002).

Geniculum (genicula - pl.): a bulge in the equatorial exine of the colpus, as a rule, associated with a separation of ectexine from endexine and the breaking of the latter (Potonié, 1934; Punt et al., 2007).

Oncus (onci - pl.): lens-shaped thickening of the outer layer of intine (hyaline) that is not resistant to acetolysis and occurs beneath the apertures (Hyde, 
Table 2. List of investigated species and specimens. The information given from the original herbarium vouchers is slightly edited, in the original language and with English translation where necessary. ERE - Institute of Botany after A. Takhtajan, National Academy of Sciences, Yerevan, Armenia; FR - Senckenberg Research Institute and Natural History Museum, Frankfurt/Main, Germany; STU - State Museum of Natural History, Stuttgart, Germany; S - specimen, H - herbarium

\begin{tabular}{|c|c|c|c|}
\hline Species & $\mathrm{S}$ & $\mathrm{H}$ & Herbarium sheet information \\
\hline Q. aegilops & & FR & Greece: Crete. Leg. F.W. Sieber, 1817 \\
\hline Q. alnifolia & & STU & $\begin{array}{l}\text { Cyprus: Distr. Nicosia / Paphos, NO Papos } \sim 20 \text { km NNO Pano Panayia, Tripylos, Cedar Valley, } \\
\text { Wood. Herb. of Dagmar Lange }\end{array}$ \\
\hline \multirow[b]{2}{*}{ Q. araxina } & 1 & ERE & $\begin{array}{l}\text { Armenia: Kapan District, river Geghanush, } 840 \text { m. Leg. K. Tamanyan, G. Fayvush, 08.04.08, } \\
\text { No. ERE } 171555\end{array}$ \\
\hline & 2 & ERE & $\begin{array}{l}\text { Армения, обл. Сюник, Мегринск. р-н, между сс. Курис и Гудемнис, } 1450 \text { мн.у.м.,близ родника. Leg. } \\
\text { Э. Габриэлян, М. Оганесян, К. Таманян, А. Нерсесян (Armenia: Sjunik Region, Meghri District, } \\
\text { between villages Curis and Gudemnis, } 1455 \mathrm{~m} \text {, near the spring. Leg. E. Gabrielian, M. Ogane- } \\
\text { syan, K. Tamanyan, A. Nersesyan), No. ERE } 171554\end{array}$ \\
\hline Q. brantii & & STU & $\begin{array}{l}\text { Iran(?): Herb. of Hegelmaier. Kurdistania (Assyria orient.), in monts Kuh-Sefin (Ditionis Erbil), } \\
\text { regione Superiore 1200-1600 m.s.m. Leg. J. Bornmüller, 21.05.1893 }\end{array}$ \\
\hline \multirow[b]{2}{*}{ Q. castaneifolia } & 1 & STU & Iran: Persia. E. Schüz, 1956 \\
\hline & 2 & STU & $\begin{array}{l}\text { Iran: Herb. of Hegelmaier, Persia borealis, Prov. Asterabad, Bender Ges, arbor in silvis. Leg. } \\
\text { Hegelmaier, 03.03.1901 }\end{array}$ \\
\hline \multirow{3}{*}{ Q. cerris } & 1 & FR & Turkey: Eastern Anatolia, Kuruca Pass, Bingoldaglar, 800 m. Leg, W. Heinz, 28.04.1989 \\
\hline & 2 & FR & $\begin{array}{l}\text { Greece: Fl. Corcyrensis, Kastrades (Corfu) auf der Besitzung des Leon Brascodima. Leg. } \\
\text { C. Baenitz }\end{array}$ \\
\hline & 3 & FR & Germany: Braunfels, Ziglerscher Garten (alt). Dr. Georg Eberle, 02.05.1952 \\
\hline \multirow[b]{2}{*}{ Q. coccifera } & 1 & FR & France: in the vicinity of Les Baux, Garique. Leg. F. Schaarschmidt, 18.04.1961, N 306 \\
\hline & 2 & ERE & $\begin{array}{l}\text { Flora Bulgaria Exsiccata, огражден планина на склоножите между ц. Каменица и ц. Сливица. Leg. } \\
\text { Ив. Ганчеж. 3. V. } 1955 \\
\text { (Bulgaria: Flora Bulgarica Exsiccata, deserted mountain slopes between Kamenica and Slivniza, } \\
\text { Leg. Iv. Ganchezh, 03.05.1955), No. ERE } 35917\end{array}$ \\
\hline Q. dschorochensis & & STU & $\begin{array}{l}\text { Turkey: NW Ankara, } 600 \text { m alt., } 15 \text { km E of Düzce, Buchen-Eichenwald. Leg. Kühne, N2347, } \\
\text { 23.05.1958 }\end{array}$ \\
\hline Q. faginea & & STU & Spain: Mallorca, Puigunyent Auwald. S. Seybold, N10105, 26.03.1988 \\
\hline \multirow[b]{2}{*}{ Q. frainetto } & 1 & FR & Hungary: Drys Diosc \\
\hline & 2 & STU & $\begin{array}{l}\text { Greece: } 700-800 \mathrm{~m} \text { alt., Peloponnes, } \mathrm{N} \text { Akhaia, } \sim 12 \mathrm{~km} \mathrm{~N} \text { of Kalavrita, tree } 8-20 \mathrm{~m} \text { high. } \\
\text { 13.05.1979 }\end{array}$ \\
\hline \multirow{2}{*}{ Q. iberica } & 1 & ERE & $\begin{array}{l}\text { Арм. ССР, Мегринск. p-он, левый борт ущелья Герун-Дарс, с.-з. склон. Leg. Э. Габриэлян, Ш. Асланян } \\
\text { (Armenia: Arm. SSR, Meghri District, left side of Gerun-Dars ravine, N-W slope. Leg. E. Gabri- } \\
\text { elian, Sh. Aslanyan), No. ERE } 66726\end{array}$ \\
\hline & 2 & ERE & $\begin{array}{l}\text { Армения, Зангезур, Кафанский р-н, Шикахохский заповедник, берег р. Цав. Leg. М. Григорян. } 26 . \\
\text { IV. } 1955 \text { (Armenia: Zangezur, Kapan District, Shikahogh Reserve, bank of Tzav river. Leg. } \\
\text { M. Grigoryan, 26.04.1955), No. ERE } 66077\end{array}$ \\
\hline \multirow[b]{2}{*}{ Q. ilex } & 1 & FR & Italy: Venetia, Prov. Venetia, Prov. Veronne, garden in Sylvis de Senveaghe. Leg. G. Rigs, Aug. 1914 \\
\hline & 2 & FR & $\begin{array}{l}\text { Italy: Flora vom Küstenland, Unterfriaul, Monte Hermada, above Duino. Leg. C. Zirnnich, } \\
\text { 19.05.1959 }\end{array}$ \\
\hline \multirow[b]{2}{*}{ Q. macranthera } & 1 & - & $\begin{array}{l}\text { Армения, Араилер, сев. склон. лес. Leg.А. Асатрян. 14.06.02 (Armenia: Arailer mountain, north } \\
\text { slope, forest. Leg. A. Asatryan, 14.06.02, personal collection) }\end{array}$ \\
\hline & 2 & ERE & $\begin{array}{l}\text { Армения, Ноемб. p-н, окр. селения Кохб, урочище Хлагом. Leg. Э. Габриэлян. 1. VI.1980 (Armenia: } \\
\text { Nojemberyan District, near Cokhb village, Chlagom hole. Leg. E. Gabrielian, 01.06.1980), No. } \\
\text { ERE } 116072\end{array}$ \\
\hline Q. persica & & STU & $\begin{array}{l}\text { Iran: Herb. of Hedelmaier, southern Persia, between Abuschir and Schiras, 1000 m NN. Leg. } \\
\text { Hedelmaier, March }\end{array}$ \\
\hline \multirow{2}{*}{ Q. petraea } & 1 & FR & $\begin{array}{l}\text { Germany: } 5917 \text { / 31|; 232. 120, Mönchwald and Dreieich, south of Kelsterbach, Mönchwald, } \\
100 \text { m NN, R } 346630 \text { / H 5545180. Leg. A. Koning, C. Werda, 02.05.2000. Nr. FIS - AK } 81 \text { / } 2000\end{array}$ \\
\hline & 2 & FR & $\begin{array}{l}\text { Germany: Rheinland-Platz, Kreis Bad Kreuznach, Rotenfels near Münster am Stein, Forest. } \\
\text { Leg. K. Muller }\end{array}$ \\
\hline Q. pontica & & FR & Germany: Frankfurt Botan. Garden, cult. Leg. H. Hupke, 06.06.1962 \\
\hline \multirow[t]{2}{*}{ Q. pubescens } & 1 & ERE & $\begin{array}{l}\text { Флора Молдавии, Кишиневск. р-н, между селами Бачкой и Сезена, на верш. холма. 15.04.1948. Det. } \\
\text { Николаева (Moldova: Flora of Moldavia, Kishinev (Chisinau) District, between villages Bachkoj } \\
\text { and Sezena, on the hilltop. Det. Nikolaeva, 15.04.1948), No. ERE } 67547\end{array}$ \\
\hline & 2 & ERE & $\begin{array}{l}\text { Herb. Hort. Bot. Jurjevensis. Ленькорань 1896. Левендовский (Azerbaijan: Lenkoran. Levendo- } \\
\text { vski, 1986), No. ERE } 10648\end{array}$ \\
\hline \multirow{5}{*}{ Q. robur } & 1 & FR & Germany: Unterfranken, Karlstadt, Kalbenstein. R.z. Strassen, 16.5.1973 \\
\hline & 2 & ERE & $\begin{array}{l}\text { Закарпатская область, УкрССР. В лесах близ Ужгорода. 28.04.1946. Leg. Ярошенко } \\
\text { (Ukraine: Ukrain. SSR: Zakarpatskaja District, in the forests near Ushgorod. Leg. Jaroshenko, } \\
\text { 28.04.1946), No. ERE 10671 }\end{array}$ \\
\hline & 3 & FR & $\begin{array}{l}\text { Germany: Rheinland-Pfalz, Kreis Bad Kreuznach, Rotenfels bei Münster am Stein, Trocken- } \\
\text { hang. Leg. K. Muller, 13.05.1980 }\end{array}$ \\
\hline & 4 & FR & Germany: Tübingen. Leg. Reinhard Weber, 05.1965, N 47.826, Stieleiche (=Q. pedunculata Ehrh.) \\
\hline & 5 & FR & Germany: Hessen, Darmstadt, Herrengarten. Leg. K. Baumann, 25.04.1994 \\
\hline
\end{tabular}


Table 2. Continued

\begin{tabular}{l|c|c|l}
\hline \hline Species & S & H & \multicolumn{1}{|c}{ Herbarium sheet information } \\
\hline \multirow{4}{*}{ Q. suber } & 1 & FR & $\begin{array}{l}\text { Italy: Flora Italica Exsiccata, Estruda, Prov. Di Grosseto, Follonica, in silvis et arvis frequens. } \\
\text { Adr. Fiori, C. Orsatti }\end{array}$ \\
\cline { 2 - 4 } & 2 & ERE & $\begin{array}{l}\text { Юж. Франция, oкр. гор. Nimes, Гарита. 7.II.1945. Leg. Narinian (France: Southern France, near } \\
\text { Nimes, Garita. Leg. Narinian, 07.02.1945), No. ERE 10682 }\end{array}$ \\
\cline { 2 - 5 } & 3 & STU & Portugal: Algarve, Meia Praia near Lagos. Leg./det: S. Seybold, 02.05.1992, N11303 \\
\cline { 2 - 5 } & 4 & FR & Switzerland: Fl. Helvetia, Lugano, Park l of Villa Luvini. Leg. C. Baenitz, 27.05.1901 \\
\hline
\end{tabular}

1955; Kuprianova, 1965; Kuprianova and Alyoshina, 1967; Punt et al., 2007). Kuprianova (1965) notes that they serve as proof of the presence of pores in the colpi.

Os (ora - pl.): as a rule, equatorially elongated inner part of a complex aperture, sometimes rounded or forming a continuous ring in the equatorial region, formed as a result of thinning or the complete absence of inner layers of the exine (Kuprianova and Alyoshina, 1967; Avetisyan and Hayrapetyan, 2002). Thus, ora are apertures in the endexine or endoapertures (Avetisyan and Hayrapetyan, 2002).

Pore (pores - pl.): more or less rounded, open-ended or membrane-coated apertures with a length and breadth ratio less than 2 (Potonié, 1934; Kuprianiova and Alyoshina, 1967).

"Spinulose" (or 'microechinate'; Solomon, 1983a,b): in the description of the pollen ornamentation of some Quercus species the presence of spine-like cone-shaped protuberances $\leq 1 \mu \mathrm{m}$ in size is assumed, rather than the true spines (spinules or echinae) that are typical for pollen grains from representatives of the families Asteraceae, Convolvulaceae, Dipsacaceae, Malvaceae, Caryophyllaceae etc.

Ubish bodies (Kosmath, 1927), or orbicules (Erdtman et al., 1961): tiny $(\sim 1 \mu \mathrm{m})$ sporopollenin granules occur on the radial and tangential wall of secretory tapetum cells. The presence of orbicules sometimes is considered a primitive feature (Sporne, 1973; Meyer, 1980; Pacini et al., 1985). According to Marquez et al. (1997), tapetum material is deposited in the tectum of the pollen grains through the Ubisch bodies.

\section{RESULTS}

\section{MORPHOLOGICAL DESCRIPTION OF POLLEN GRAINS}

\section{Genus Quercus}

\section{Subgenus Quercus}

\section{Section Quercus}

\section{Subsect. Ponticae}

\section{Q. pontica K.Koch}

Pl. 1

Description. Pollen grains 3-zonocolp-poroidate (3-zonocolp-porate), from oblong to spheroidal, angularly rounded; outline in polar view rounded-3-lobed; polar axis 17.5-22.9 $\mu \mathrm{m}$, equatorial diameter 19.1-23.7 $\mu \mathrm{m}$. Colpi usually geniculate, not wide or narrow, with smooth, well-delineated edges and pointed ends; colpus length $\sim 4 / 5$ of polar axis; apocolpium diameter 6.5-9.1 $\mu \mathrm{m}$, mesocolpium width 14.1-17.7 $\mu \mathrm{m}$. Pores weakly expressed, with undulated margins or rounded. Exine thin, 0.7-1.0 $\mu \mathrm{m}$. With LM, exine ornamentation regularly finely verrucate; with SEM, ornamentation punctategranulate-microtuberculate, puncta rounded, sometimes elongate; granula arranged on and between tuberculi; tuberculi varying in size.

Remarks. Monoszon (1954) also noted the presence of well-defined pores for some pollen grains. Smit (1973) placed this species in type A (Quercus robur/petraea) with colpate apertures. The ornamentation shows microverrucae and flatter parts of the tectum, which are covered with rounded spinuloid processes. Denk and Grimm (2009) placed this species in the infrageneric group Quercus, with a verrucate type of ornamentation.

\section{Subsect. Quercus}

\section{Q. robur L.}

Pl. 2

Description. Pollen grains 3(rarely 4)-zonocolp-poroidate or 3(rarely 4)-zonocolp-porate, from oblong to oblate-spheroidal; outline in polar view rounded-triangular or rounded3-lobed; polar axis 15.5-23.9 $\mu \mathrm{m}$, equatorial diameter 21.7-26.7 $\mu \mathrm{m}$. Colpi sometimes geniculate, from wide to narrow, almost slit-like, with slightly wavy margins and pointed ends; colpus length $2 / 3-3 / 4$ of polar axis; apocolpium diameter 6.8-9.2 $\mu \mathrm{m}$, mesocolpium width 9.7-15.3 $\mu \mathrm{m}$. Pores usually poorly expressed, circular. Exine thickness 1.8-2.1 $\mu \mathrm{m}$. Exine ornamentation verrucate (LM); with SEM, ornamentation punctate-granulate-verrucate; puncta numerous, rounded, sometimes elongate; granula occur not only on the tectum between verrucae but also on the verrucae; 


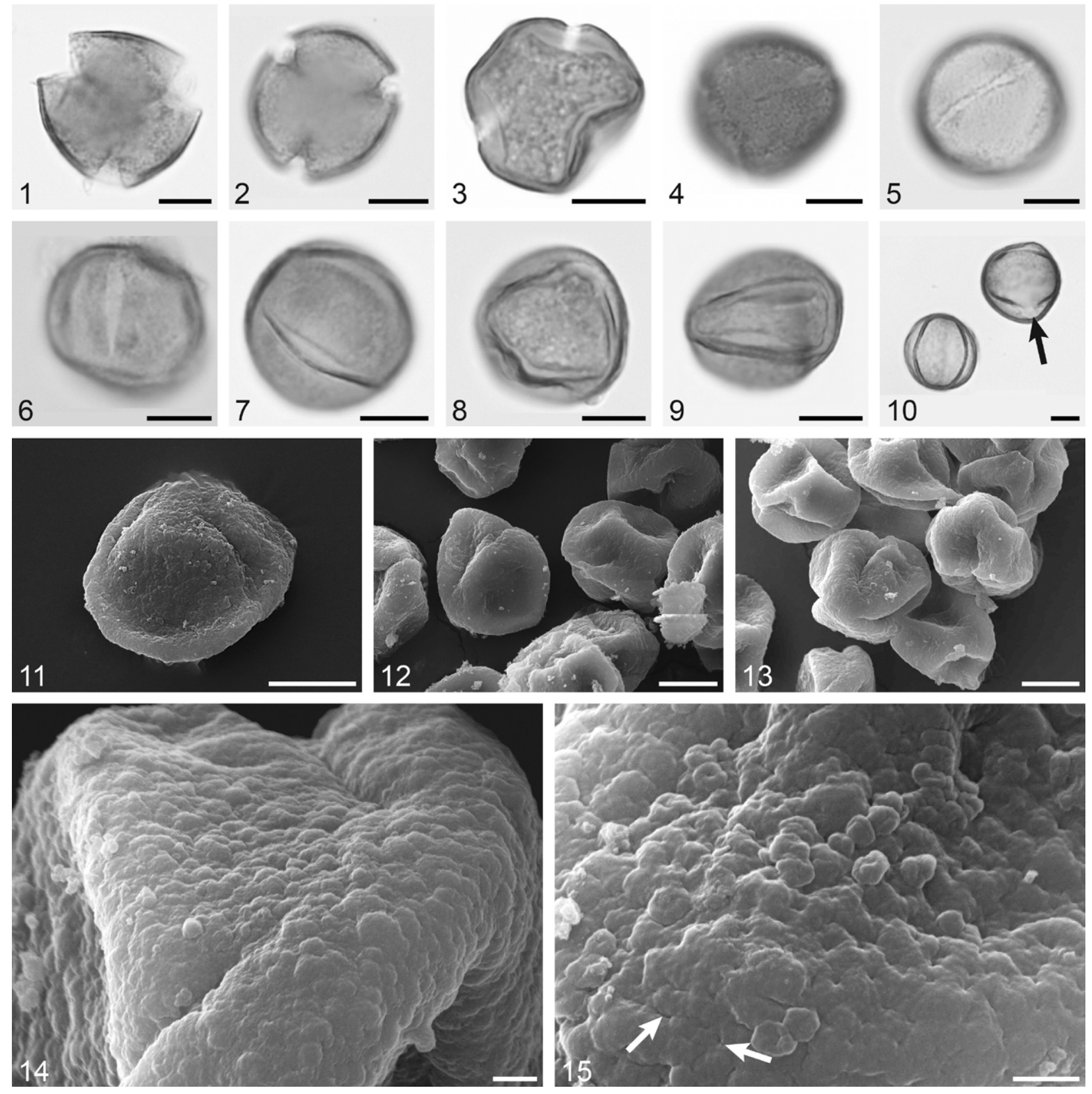

Plate 1. Pollen grains of Quercus pontica. 1-10. LM micrographs: 1-4. polar view; 5, 6. equatorial view, colpus; 7-10. equatorial view, mesocolpium, arrow in 10 indicates pore (scale bar $10 \mu \mathrm{m} ; 1,2,5-10$ acetolyzed, 3, 4 stained with fuchsine); 11-15. SEM micrographs: 11. equatorial view; 12, 13. pollen groups (scale bar $10 \mu \mathrm{m}$ ); 14, 15. ornamentation, arrows in 15 indicate puncta (scale bar $1 \mu \mathrm{m}$ )

verrucae rounded, varying in size, often located in small groups, fused laterally; sometimes the boundary between such groups is flattened, and zones with a smooth, sometimes perforated surface were observed (Pl. 2, fig. 17).

Remarks. Monoszon (1954, 1961) saw this species as close to $Q$. petraea, the main difference between these two being a regular (Q. petraea) or irregular (Q. robur) arrangement of verrucate elements on the pollen grain surface. Kuprianova (1965) documented varying sizes of pollen grains in samples gathered from different natural habitats. Smit
(1973) placed this species in his type A (Quercus robur/petraea). Van Benthem et al. (1984) described the exine ornamentation as scabrate-verrucate (also for Q. petraea, Q. pubescens), whereas Denk and Grimm (2009) called it verrucate and Panahi et al. (2012) scabrate and gemmate, with secondary microverrucate ornamentation on the sculptural patterns.

\section{Q. petraea L. ex Liebl.}

\section{Pl. 3}

Description. Pollen grains 3-zonocolpate, sometimes 3-zonocolp-poroidate, oblong to 


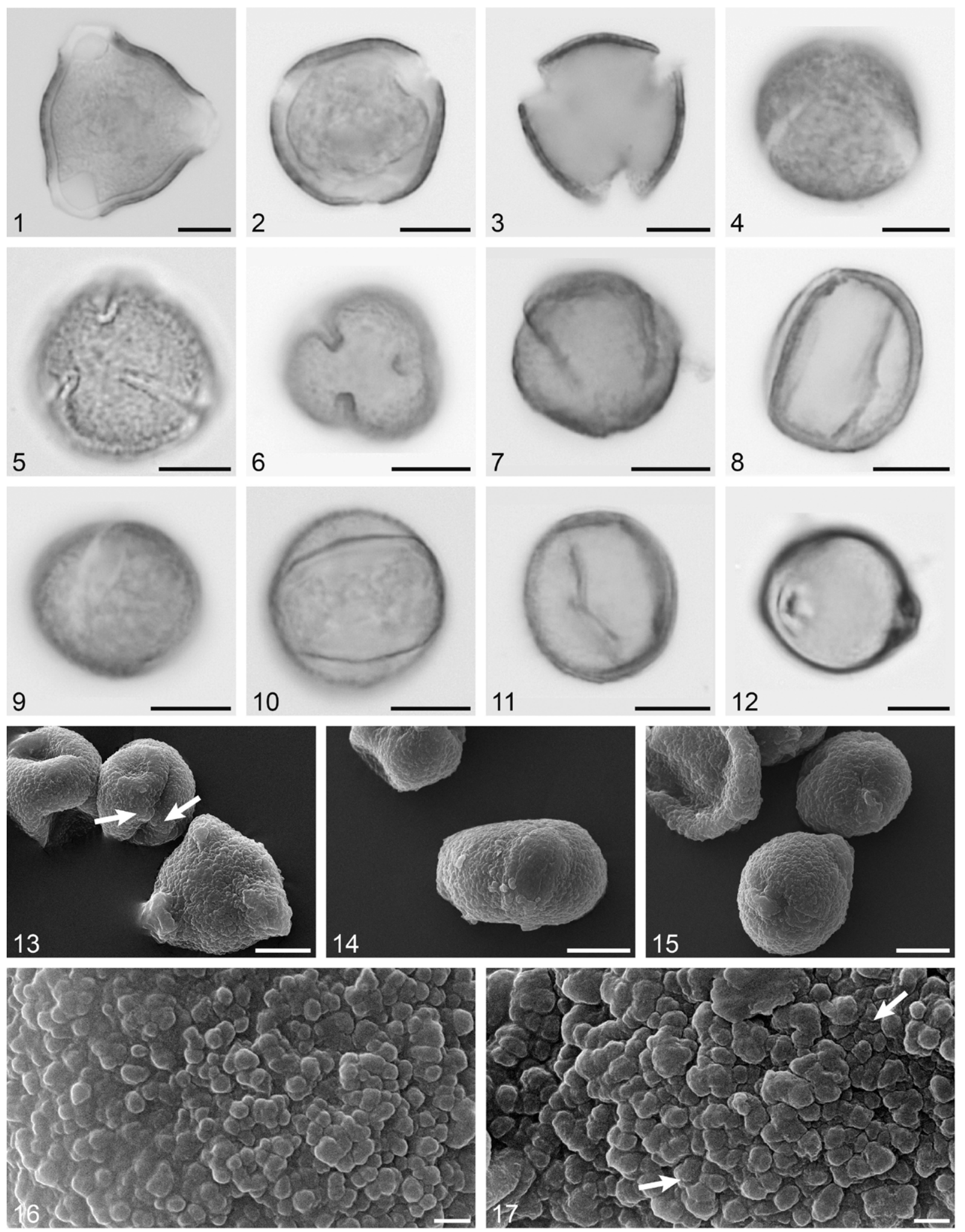

Plate 2. Pollen grains of Quercus robur (specimen 5). 1-12. LM micrographs: 1-7. polar view; 8-12. equatorial view (scale bar $10 \mu \mathrm{m} ; 3,6-10$ acetolyzed, 1, 2, 4, 5 stained with fuchsine); 13-17. SEM micrographs: 13. polar and equatorial view, arrows indicate geniculum; 14, 15. equatorial view, colpus (scale bar $10 \mu \mathrm{m}$ ); 16, 17. ornamentation, arrows in 17 mark granules on tectum and on verruca (scale bar $1 \mu \mathrm{m}$ )

oblate-spheroidal; outline in polar view rounded-triangular; polar axis 22.5-28.0 $\mu \mathrm{m}$, equatorial diameter 23.1-27.8 $\mu \mathrm{m}$. Colpi geniculate, rather narrow, with slightly wavy margins and needle-like pointed ends; colpus length $2 / 3-3 / 4$ of polar axis; apocolpium diameter 9.2-10.7 $\mu \mathrm{m}$, mesocolpium width 16.5-18.6 $\mu \mathrm{m}$. Pores weakly expressed, if present. Exine thickness 1.9-2.3 $\mu \mathrm{m}$; columellae separate and thick (Pl. 3, fig. 3). Exine 

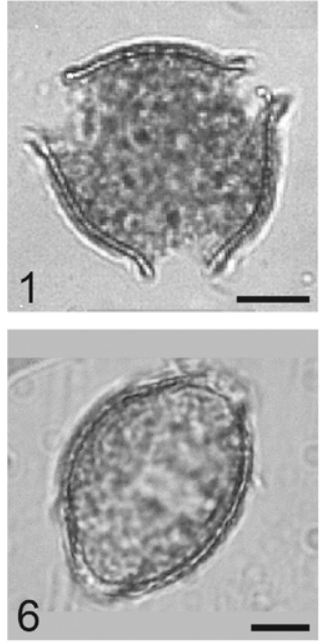

2
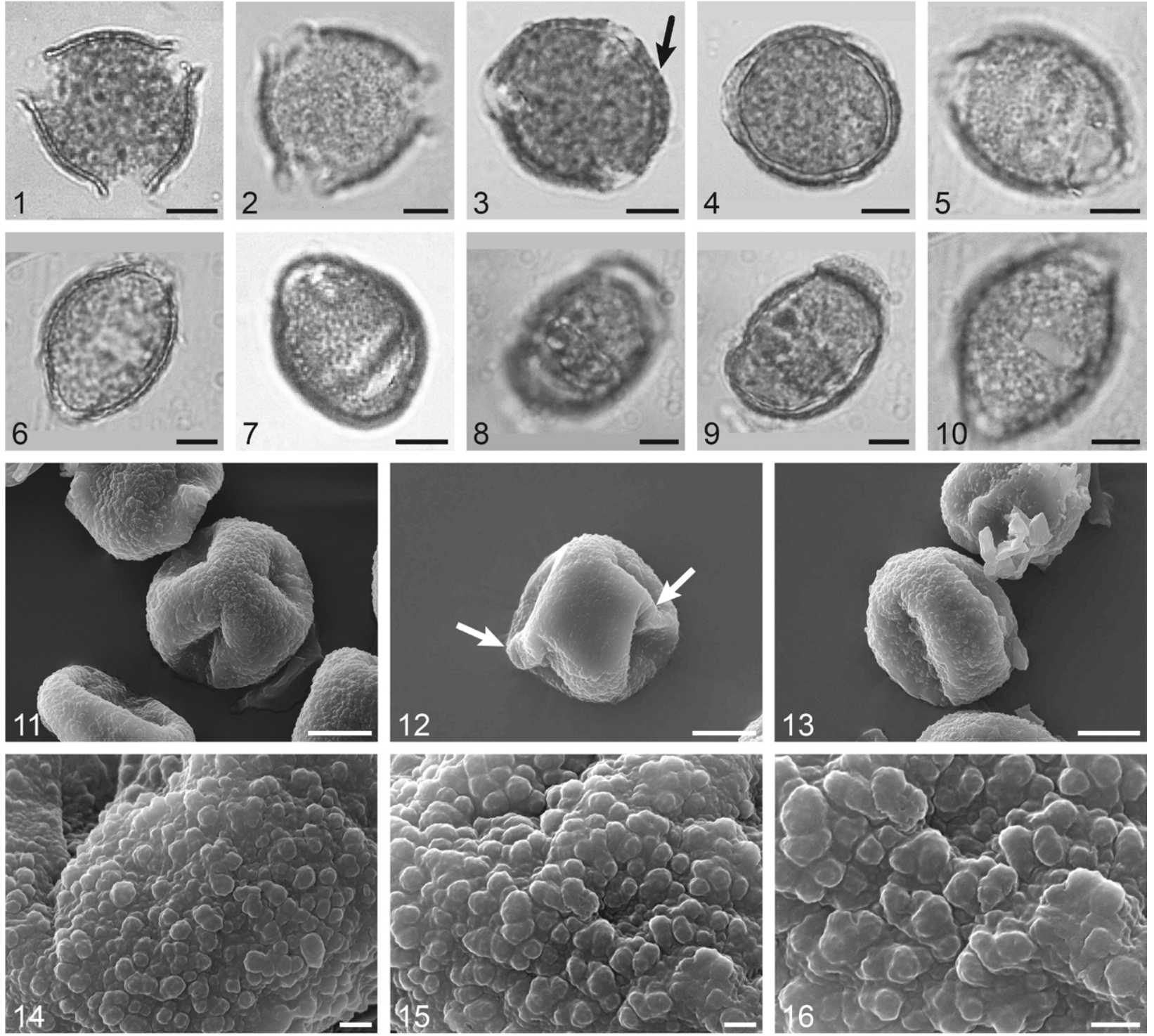

Plate 3. Pollen grains of Quercus petraea (specimen 1). 1-10. LM micrographs: 1-4. polar view, arrow in 3 indicates columellae; 5-7. equatorial view, mesocolpium; 8-10. equatorial view, colpi (scale bar $10 \mu \mathrm{m} ; 1,2,7,10$ acetolyzed, 3-6, 8, 9 stained with fuchsine); 11-16. SEM micrographs: 11. polar view; 12, 13. equatorial view, mesocolpium, arrows in 12 indicate geniculae (scale bar $10 \mu \mathrm{m}$ ); 14-16. ornamentation (scale bar $1 \mu \mathrm{m}$ )

ornamentation verrucate (LM); with SEM, ornamentation punctate-granulate-verrucate; puncta rounded, sometimes elongate; granula arranged not only on tectum between verrucae but sometimes on verrucae as well (poorly expressed); verrucae varying in size, rounded, as a rule located in small groups, fused laterally.

Remarks. Monoszon (1954) emphasized the considerable variability of pollen size. Kuprianova (1965) and Kuprianova and Alyoshina (1972) noted the finely uniformly tuberculate type of exine ornamentation. Van Benthem et al. (1984) described it as scabrate-verrucate, and Denk and Grimm (2009) as verrucate. Smit (1973) placed this species in type A (Quercus robur/petraea).
Q. iberica Steven ex M.Bieb.

Pl. 4

Description. Pollen grains 3-zonocolpate or 3-zonocolp-poroidate, oblong to almost spheroidal; outline in polar view rounded-triangular or rounded-lobed; polar axis 24.5-27.8 $\mu \mathrm{m}$, equatorial diameter 24.2-33.1 $\mu \mathrm{m}$. Colpi usually geniculate, not wide or narrow, with smooth, well-rounded margins and pointed ends; colpus length $3 / 5-3 / 4$ of polar axis; apocolpium diameter 7.5-10.2 $\mu \mathrm{m}$, mesocolpium width 14.7-23.8 $\mu \mathrm{m}$. Pores, if present, usually weakly expressed, circular. Exine thickness 1.5-1.7 $\mu \mathrm{m}$ on mesocolpium, endexine poorly expressed; columellae separate, regularly situated (Pl. 4, figs 1, 2); endexine becomes 


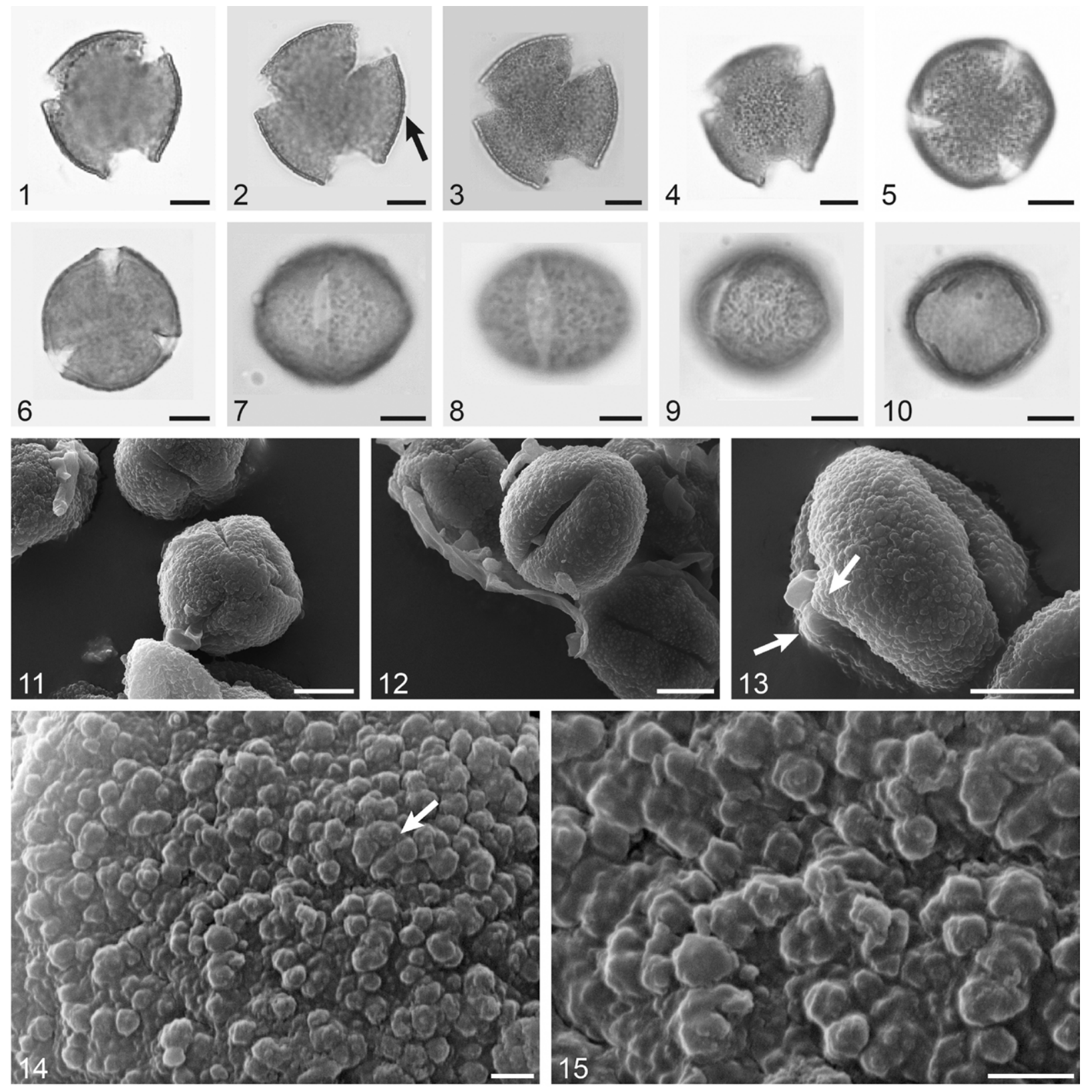

Plate 4. Pollen grains of Quercus iberica (specimen 1). 1-10. LM micrographs: 1-6. polar view, arrow in 2 marks columellae; 7, 8. equatorial view, colpi; 9, 10. equatorial view, mesocolpium (scale bar $10 \mu \mathrm{m} ; 1-4,6,10$ acetolyzed, 5, 7-9 stained with fuchsine); 11-15. SEM micrographs: 11. polar view; 12. equatorial view, colpus; 13. equatorial view, mesocolpium, arrows indicate geniculum (scale bar $10 \mu \mathrm{m}) ; 14,15$. ornamentation, arrow in 14 indicates verrucae arranged in small groups and fused laterally (scale bar $1 \mu \mathrm{m}$ )

twice as thick closer to apertures. Exine ornamentation verrucate (LM); ornamentation under SEM punctate-granulate-verrucate; puncta rounded, sometimes elongate; granula arranged not only on tectum between verrucae but also on verrucae (poorly expressed); verrucae rounded, located in small groups, fused laterally.

Remarks. Monoszon (1954) also noted the varying lengths of colpi. Panahi et al. (2012: 39) described this species as $Q$. petraea (Matt.) Liebl. subsp. iberica (Steven) Krassiln. with gemmate-verrucate ornamentation of the exine 'which is mostly sharp-pointed and angular'.

Along with their significant similarity in pollen characteristics, the main difference between the investigated specimens of the species $Q$. petraea and Q. iberica (accepted as Q. petraea (Matt.) Liebl. subsp. iberica (Steven) Krasiln. by Menitsky and others; see Tab. 1) is the thickness of the exine layer. Exine thickness for pollen grains of $Q$. petraea reaches 1.9$2.3 \mu \mathrm{m}$; for $Q$. iberica it varies within the range of $1.5-1.7 \mu \mathrm{m}$ (measured in 10 grains per specimen, from 2 specimens). This is in accordance 
with Papini et al. (2011), who wrote that 'The taxonomical status of $Q$. iberica $(Q$. petraea subsp. iberica according to some authors) was analysed with respect to $Q$. petraea. Despite the strict phylogenetic relationship between these two species, the genetic distance (Kimura) was compatible with the hypothesis of maintaining the two taxa separated'.
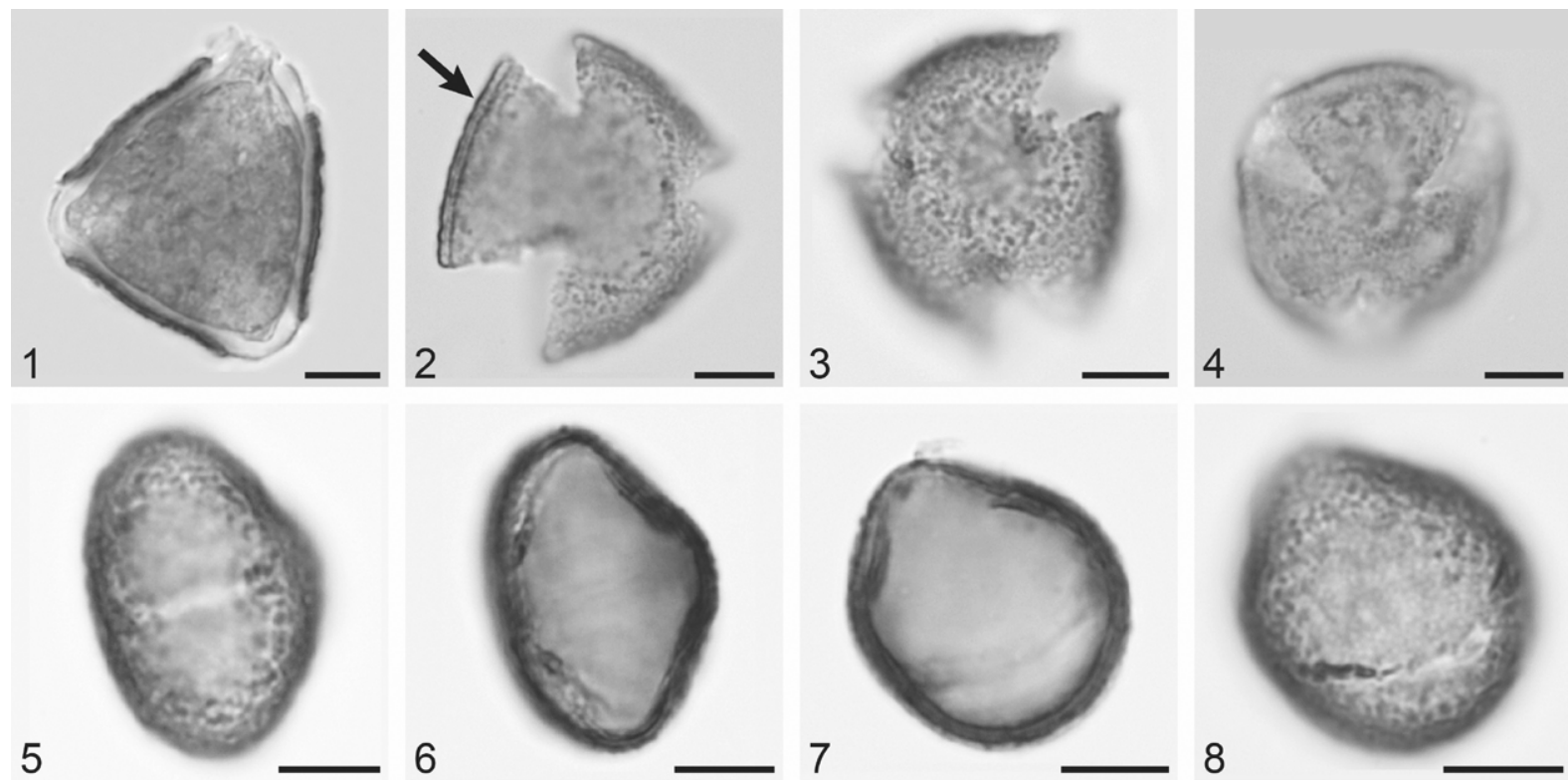

6
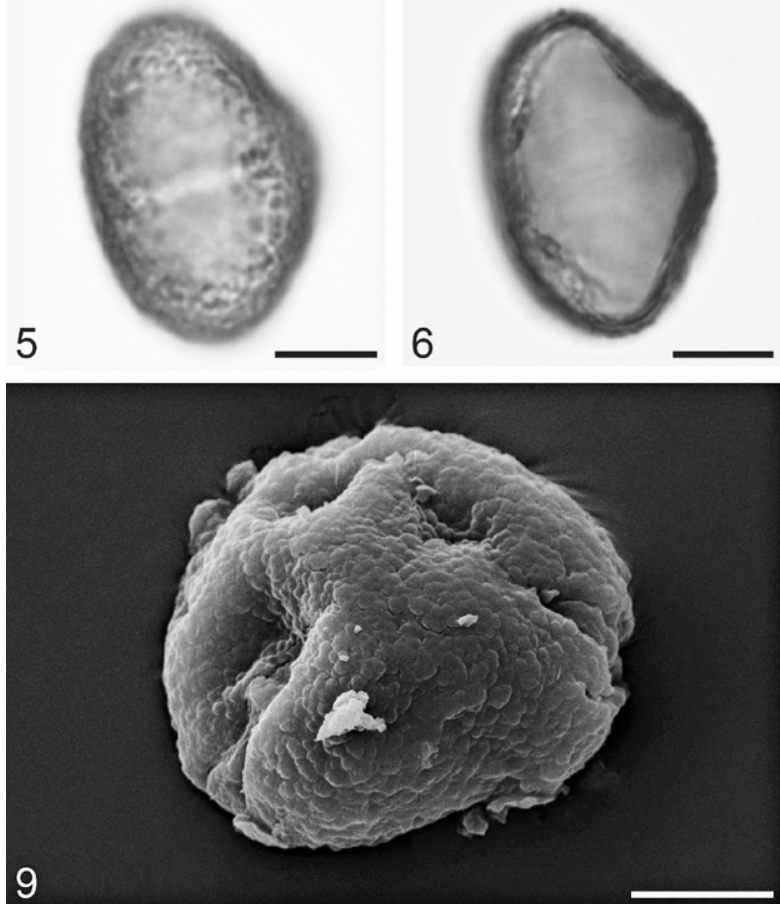

7
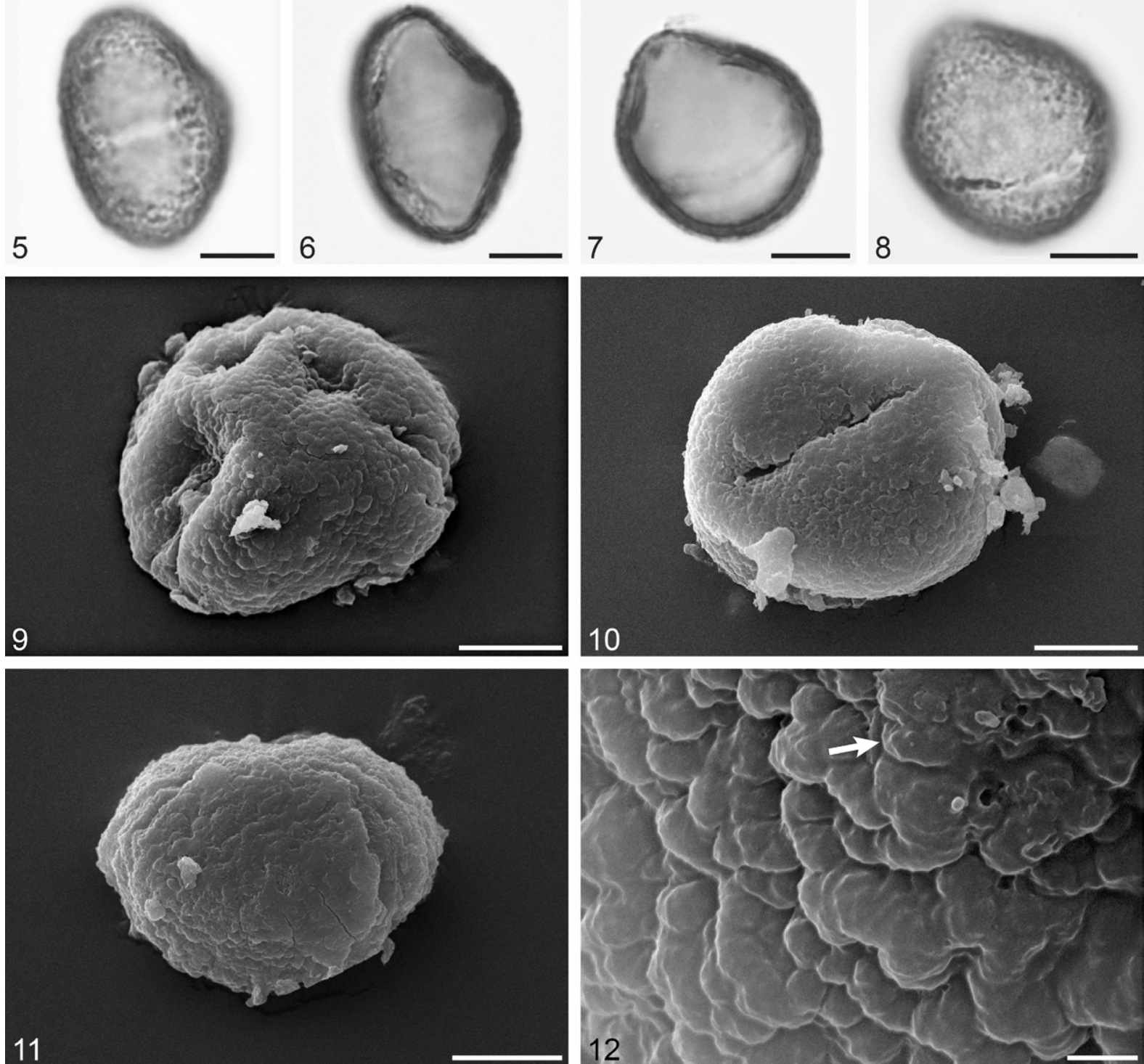

Plate 5. Pollen grains of Quercus dshorochensis. 1-8. LM micrographs: 1-4. polar view, arrow in 2 marks columellae; 5. equatorial view, colpus; 6-8. equatorial view, mesocolpium (scale bar $10 \mu \mathrm{m} ; 2,3,5-8$ acetolyzed, 1, 4 stained with fuchsine); 9-12. SEM micrographs: 9. polar view; 10. equatorial view, colpus; 11. equatorial view, mesocolpium (scale bar $10 \mu \mathrm{m})$; 12. ornamentation with tuberculum (arrow) with fine granules and spines (scale bar $1 \mu \mathrm{m}$ ) 
equatorial diameter 22.3-28.7 $\mu \mathrm{m}$. Colpi usually without geniculum, not wide, sometimes narrow, almost slit, with wavy margins and pointed ends; colpus length $2 / 3-3 / 4$ of polar axis; apocolpium diameter 8.7-10.4 $\mu \mathrm{m}$, mesocolpium width $21.8-24.0 \mu \mathrm{m}$. Pores, if present, sometimes clearly defined and circular. Exine thickness 2.3-2.6 $\mu \mathrm{m}$; columellae thick, separate ( $\mathrm{Pl}$. 5, fig. 2). Exine ornamentation verrucate (LM); with SEM, exine ornamentation punctate-tuberculate, puncta rounded, sometimes elongate; surface of individual tuberculum undulate, fine granules or spines located between and on tuberculi.

Remarks. Q. dshorochensis is considered a synonym of $Q$. petraea subsp. dshorochensis (K.Koch) Menitsky (see Tab. 1). However, in our samples the pollen morphology is markedly different from that of $Q$. petraea, in particular by the type of exine ornamentation.

\section{Subsect. Macrantherae}

\section{Q. macranthera}

Fisch. et C.A.Mey. ex Hohen.

Pl. 6

Description. Pollen grains 3-zonocolpate or 3-zonocolp-poroidate, scarcely spheroidal or broadly ellipsoidal, outline in polar view rounded-triangular; polar axis 25.6-34.2 $\mathrm{\mu m}$, equatorial diameter 28.2-38.7 $\mu \mathrm{m}$. Colpi geniculate, not wide or very narrow, almost slit-like, with wavy margins and needle-like pointed ends; colpus length 2/3-3/4 of polar axis; apocolpium diameter 9.8-14.1 $\mathrm{\mu m}$, mesocolpium width 18.9-22.1 $\mu \mathrm{m}$. Exine thickness 2.4$2.6 \mu \mathrm{m}$, with thick and separate columellae, sometimes expanding at end (Pl. 6, fig. 2); closer to apertures the ectexine and endexine separate, forming clearly defined geniculum ( $\mathrm{Pl}$. 6, fig. 11). Exine ornamentation verrucate (LM); with SEM, ornamentation punctate-granulateverrucate; sometimes granula arranged not only on tectum between verrucae but on verrucae as well; verrucae rounded, usually irregularly located in groups, fused laterally.

Remarks. Samoilovich (1950) mentioned the thick exine and well-distinguishable granulate ornamentation. According to Monoszon (1954), pollen grains of this species have short colpi. Denk and Grimm (2009) placed the species in the infrageneric group Quercus, with a verrucate type of ornamentation. Panahi et al. (2012) noted verrucate structure, gemmate sculpture and a microverrucate-microechinate type of suprasculpture with spinous protuberances.

\section{Q. frainetto Ten.}

Pl. 7

Description. Pollen grains 3-zonocolpate, 3-zonocolp-poroidate, predominately spheroidal or angular-spheroidal, outline in polar view rounded-triangular; polar axis 22.3-32.2 $\mu \mathrm{m}$, equatorial diameter 24.8-31.9 $\mu \mathrm{m}$. Colpi sometimes geniculate, rather narrow, with slightly wavy margins and pointed ends; colpus length 3/4-7/8 of polar axis; apocolpium diameter 8.3$10.5 \mu \mathrm{m}$, mesocolpium width 18.5-25.4 $\mu \mathrm{m}$. Pores, if present, usually weakly expressed. Exine thickness 1.7-2.2 $\mu \mathrm{m}$, with thick, separate columellae (Pl. 7, fig. 4). Exine ornamentation verrucate (LM); with SEM, exine ornamentation punctate-granulate-verrucate; puncta numerous; granula arranged on tectum between verrucae; verrucae almost the same size, rounded, usually located in small groups, fused laterally, sometimes solitary.

Remarks. Denk and Grimm (2009) placed this species in the infrageneric group Quercus, with a verrucate type of ornamentation.

\section{Subsect. Gallifera}

\section{Q. araxina (Trautv.) Grossh.} Pl. 8

Description. Pollen grains 3-zonocolp-poroidate (occasionally 3-zonocolp-porate), oblong to oblate, outline in polar view triangular or rounded-triangular; polar axis 18.5-23.5 $\mu \mathrm{m}$, equatorial diameter 15.8-27.0 $\mu \mathrm{m}$. Colpi usually geniculate, mostly narrow, sometimes almost slit-like, with smooth, sometimes slightly wavy margins and pointed ends; colpi membrane with verrucae ( $\mathrm{Pl}$. 8, figs 5, 11); colpus length $3 / 4-4 / 5$ of polar axis; apocolpium diameter 7.0-8.2 $\mathrm{mm}$, mesocolpium width 14.2-20.1 $\mathrm{mm}$. Pores often poorly expressed, with laciniate margins ( $\mathrm{Pl}$. 8, fig. 9). Exine thickness on mesocolpium 1.7-2.0 $\mathrm{\mu m}$, columellae thin and separate (Pl. 8, fig. 2); both ectexine and endexine become thicker closer to apertures; lens-shaped onci occur beneath apertures (Pl. 8, fig. 1). Exine ornamentation verrucate (LM); ornamentation under SEM 
punctate-granulate-verrucate; puncta numerous, rounded; granula arranged on tectum between verrucae; verrucae (or microverrucae) varying in size and rounded, usually located in small groups, fused laterally, sometimes solitary.

Remarks. Panahi et al. (2012) accepted $Q$. araxina as a synonym of $Q$. infectoria
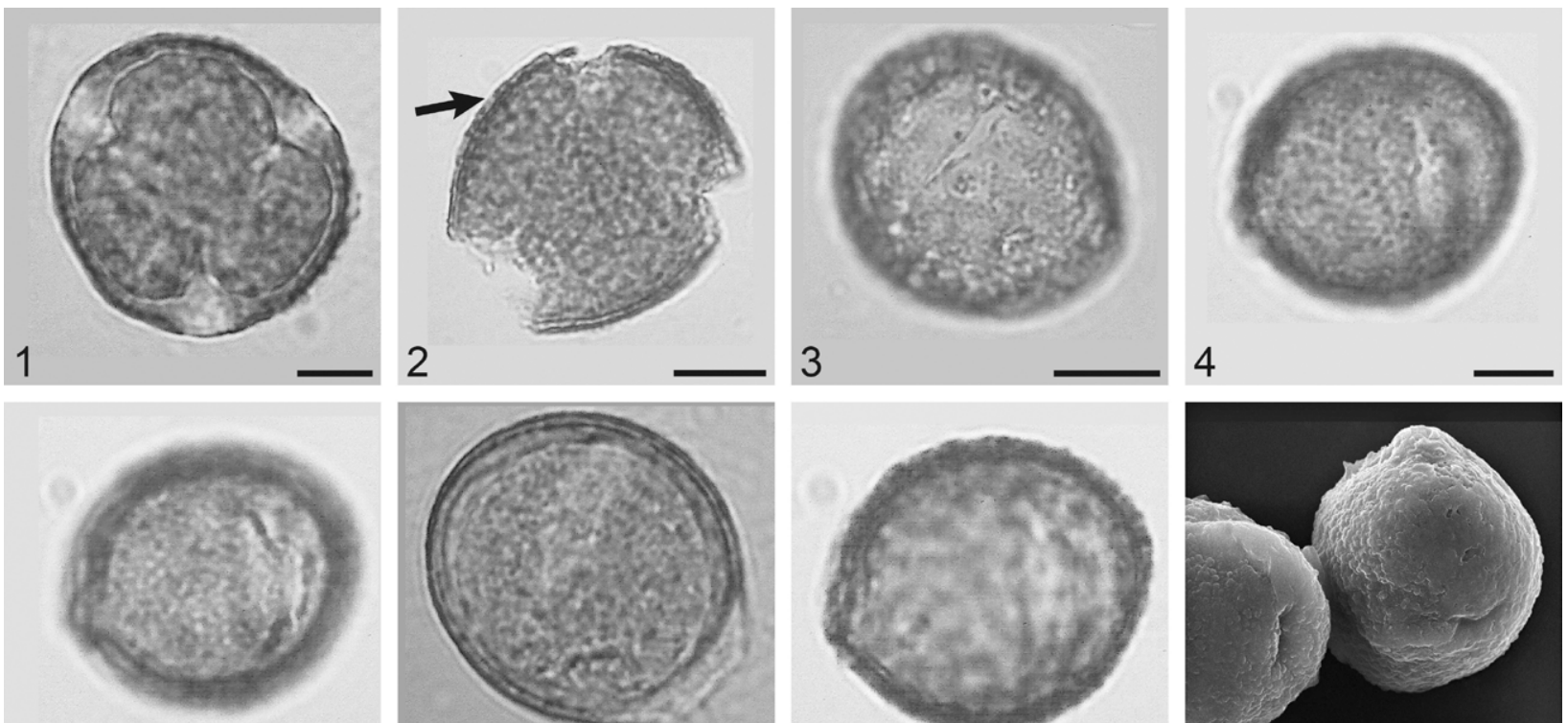

5
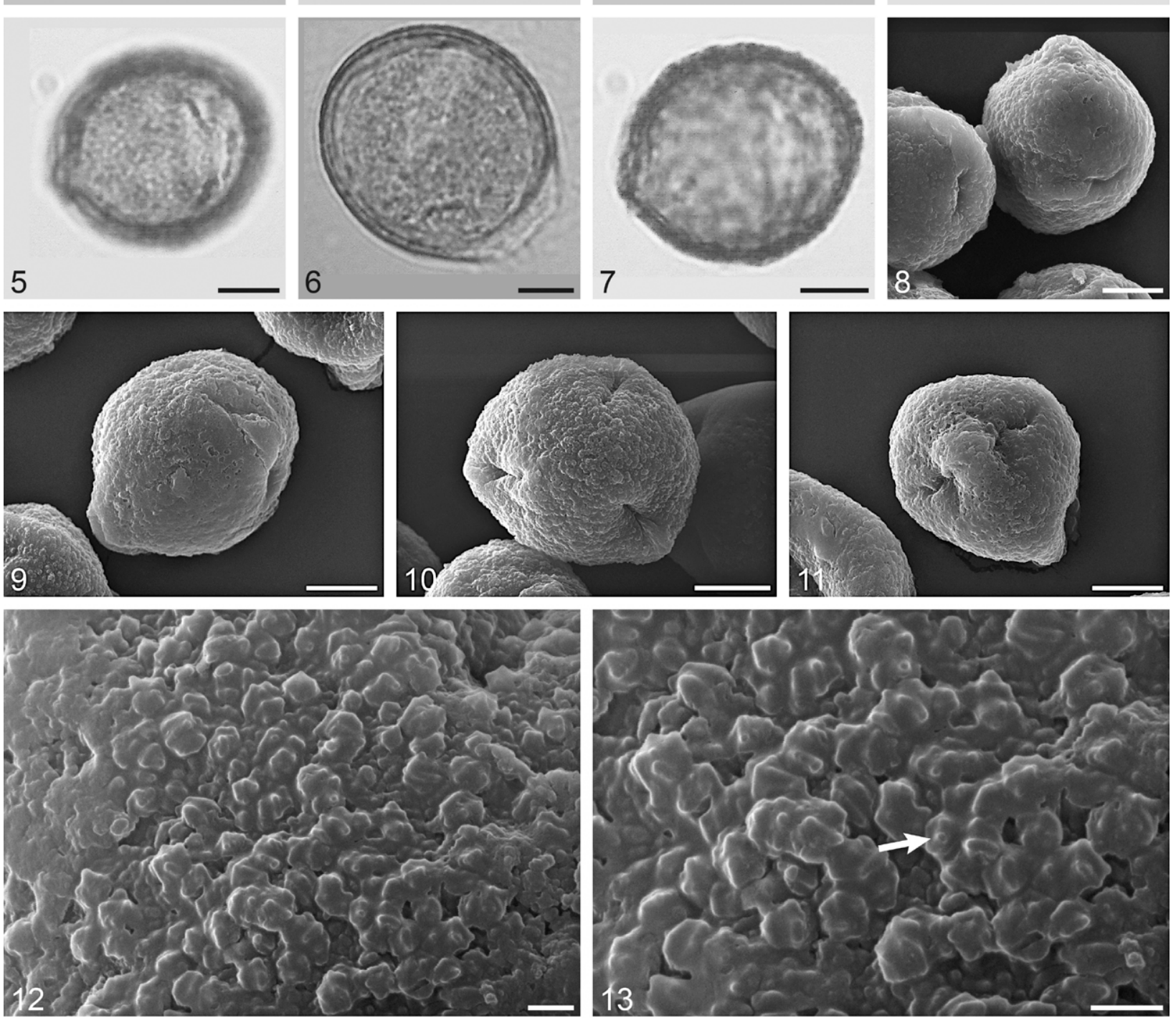

Plate 6. Pollen grains of Quercus macranthera (specimen 1). 1-7. LM micrographs: 1, 2. polar view, arrow in 2 marks columellae; 3-7. equatorial view (scale bar $10 \mu \mathrm{m} ; 2-5,7$ acetolyzed, 1, 6 stained with fuchsine); 8-13. SEM micrographs: 8, 9. equatorial view, mesocolpium; 10. polar view; 11. equatorial view, colpus with geniculum (scale bar $10 \mu \mathrm{m}$ ); 12, 13. ornamentation with granulae on verrucae (arrow) (scale bar $1 \mu \mathrm{m}$ ) 


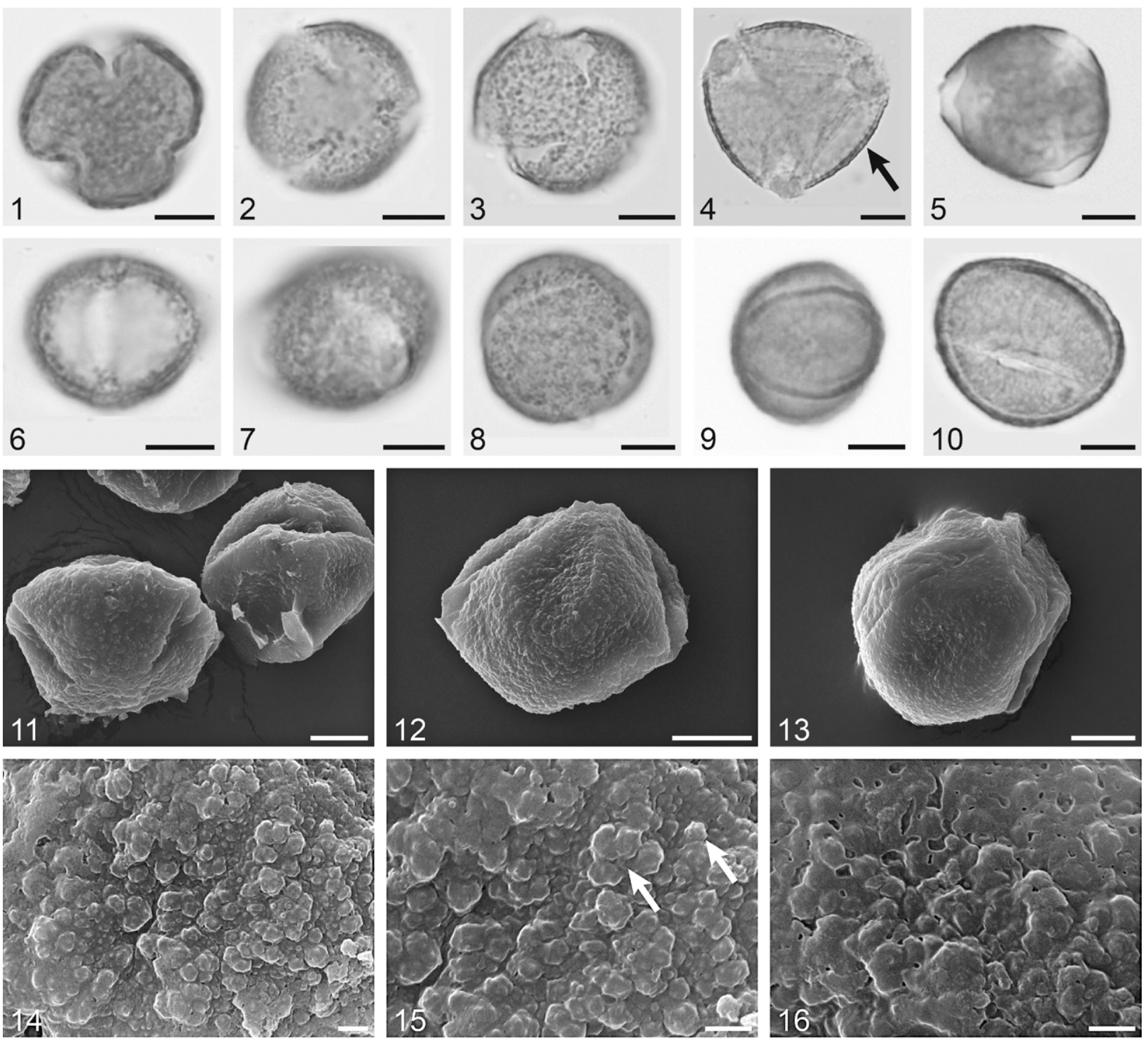

Plate 7. Pollen grains of Quercus frainetto (specimen 1). 1-10. LM micrographs: 1-5. polar view, arrow in 4 marks columellae; 6-10. equatorial view (scale bar $10 \mu \mathrm{m} ; 1-3,6-10$ acetolyzed, 4,5 stained with fuchsine); 11-16. SEM micrographs: 11. pollen group; 12, 13. equatorial view, mesocolpium (scale bar $10 \mu \mathrm{m}$ ); 14-16. ornamentation, arrows in 15 indicate verrucae which are solitary or fused laterally (scale bar $1 \mu \mathrm{m}$ )

\section{Q. pubescens Willd.}

Pl. 9

Description. Pollen grains 3-zonocolpate, 3-zonocolp-poroidate, slightly spheroidal or broadly ellipsoidal, outline in polar view rounded3-lobed; polar axis 19.7-27.3 $\mu \mathrm{m}$, equatorial diameter 18.5-32.9 $\mu \mathrm{m}$. Colpi narrow, almost slit-like with slightly wavy margins and needlelike pointed ends, sometimes geniculate; colpus length 2/3-3/4 of polar axis; apocolpium diameter 8.2-9.1 $\mu \mathrm{m}$, mesocolpium width 11.5-12.5 $\mu \mathrm{m}$. Pores, if present, usually weakly expressed. Exine thickness 1.4-1.6 $\mu \mathrm{m}$, columellae thin and separate (Pl. 9, fig. 1). Exine ornamentation verrucate (LM); with SEM, ornamentation punctate-granulate-verrucate; puncta numerous, rounded, sometimes elongate; granula arranged not only on tectum between verrucae but sometimes also on verrucae (poorly expressed); verrucae varying in size and rounded, often located in small groups, fused laterally.

Remarks. According to Monoszon (1961), sporoderm thickness varies in different specimens. Kuprianova and Alyoshina (1972) mentioned that this species forms hybrids with $Q$. robur and $Q$. petraea, so pollen grains have great variability in size, and the percentage of deformed grains is 20-60\%. In comparison with pollen of $Q$. robur and $Q$. petraea, the main distinctive features of pollen of $Q$. pubescens are larger size and more prominent exine ornamentation. 
Smit (1973) placed this species in type A (Quercus robur/petraea). Colombo et al. (1983) wrote that $Q$. pubescens exhibits very typical exine sculpture: irregularly scattered and variously sized verrucae result in a rough morphology, the tectum and the verrucae surface being covered by microsculpture; perforations in the tectum are frequent.

\section{Q. faginea Lam.}

Pl. 10

De s cription. Pollen grains 3-zonocolp-poroidate or 3-zonocolp-porate, predominantly spheroidal or oblate-spheroidal, outline in polar view rounded-triangular; polar axis 21.0-25.1 $\mathrm{mm}$, equatorial diameter 20.1-26.3 $\mu \mathrm{m}$. Colpi wide,

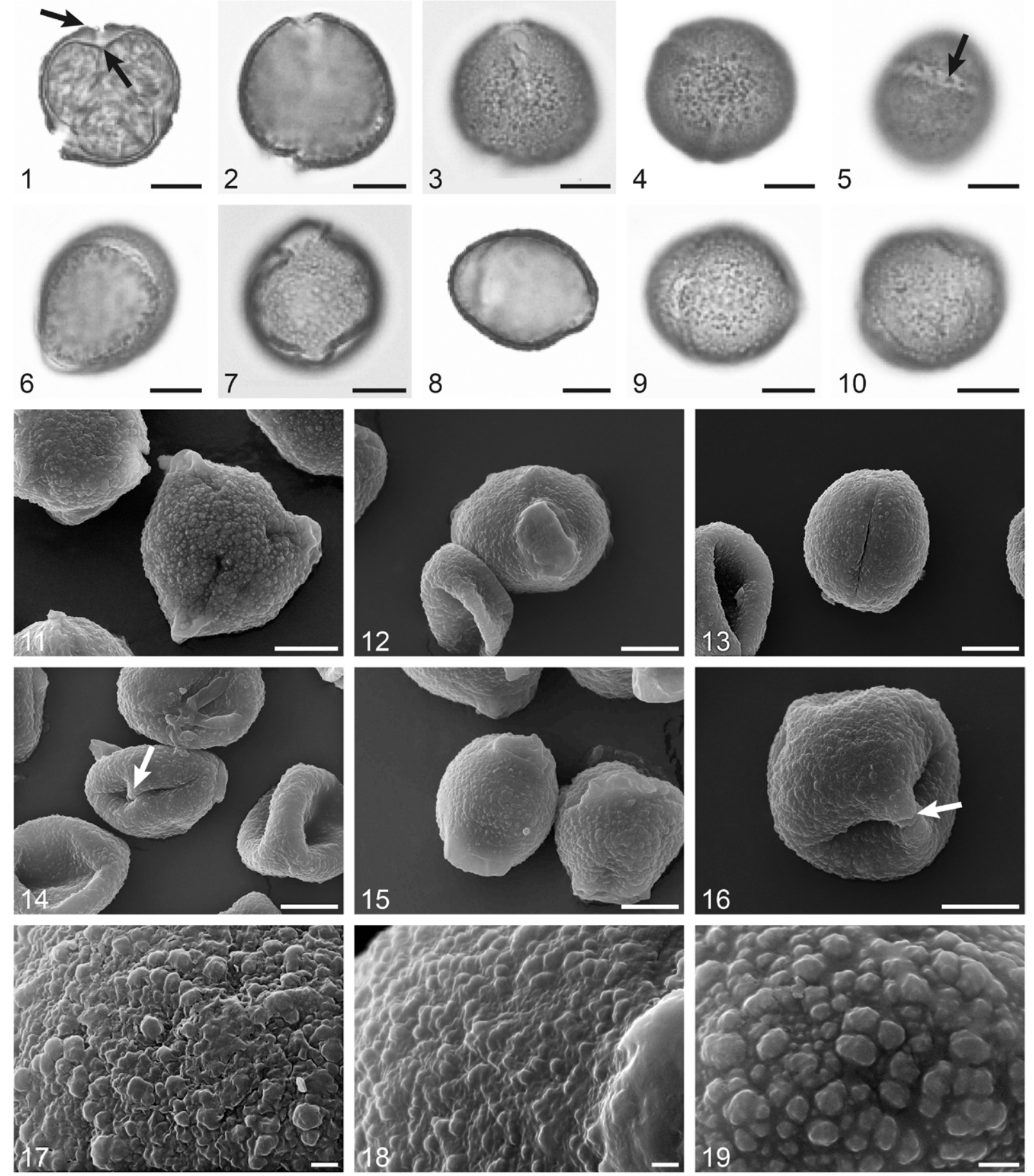

Plate 8. Pollen grains of Quercus araxina (specimen 2). 1-10. LM micrographs: 1-4. polar view, arrows in 1 indicate oncus and thickening of ectexine and endexine towards apertures; 5. colpus membrane ornamented with verrucae (arrow); 6-10. equatorial view, mesocolpium (scale bar $10 \mu \mathrm{m} ; 2-4,8-10$ acetolyzed, 1, 5-7 stained with fuchsine); 11-19. SEM micrographs: 11. polar view; 12, 13. equatorial view, colpus; 14. colpus with geniculum; 15, 16. equatorial view, mesocolpium, arrows in 14 and 16 indicate geniculae (scale bar $10 \mu \mathrm{m}$ ); 17-19. ornamentation (scale bar $1 \mu \mathrm{m}$ ) 

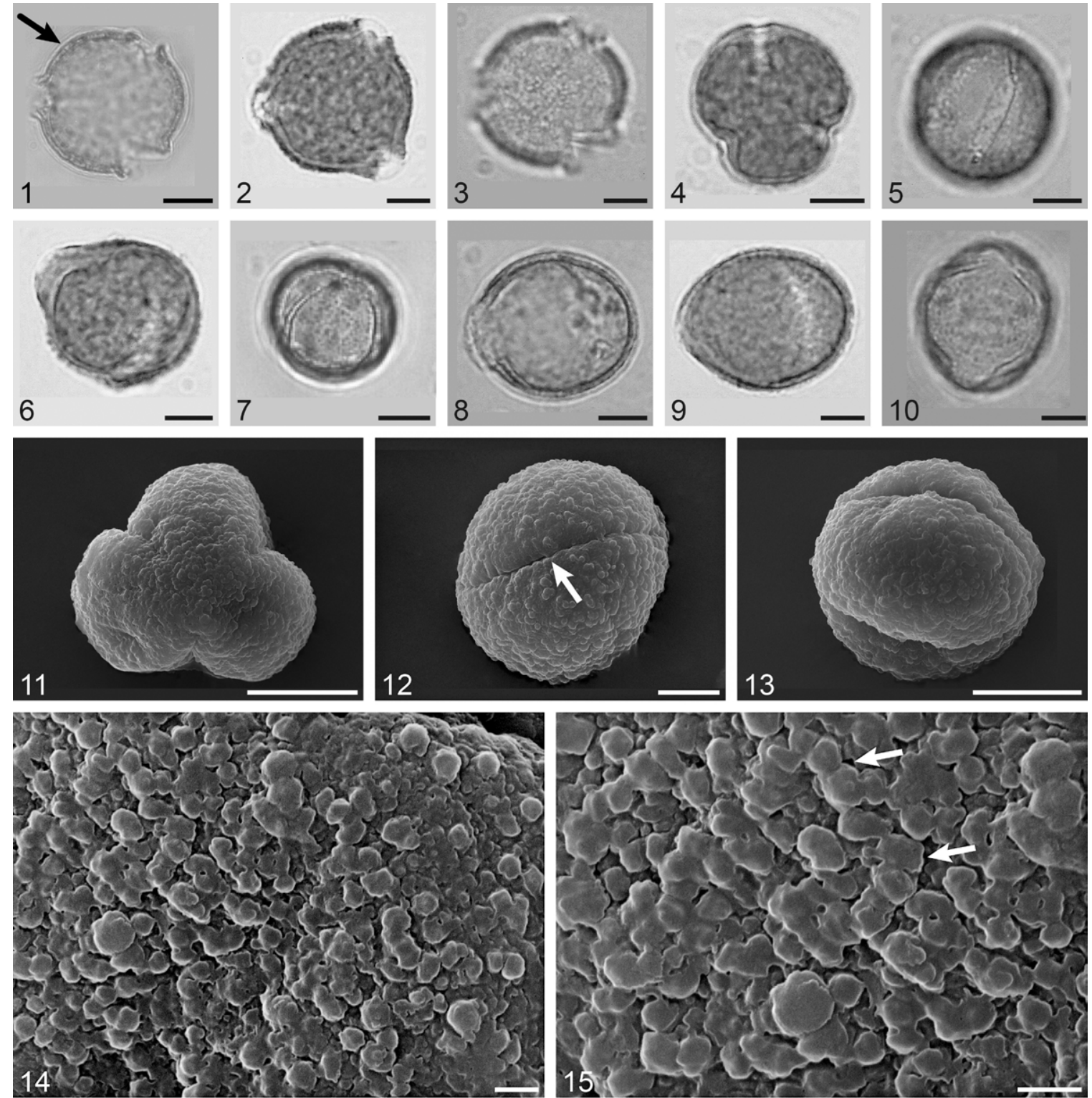

Plate 9. Pollen grains of Quercus pubescens (specimen 1). 1-10. LM micrographs: 1-4. polar view, arrow in 1 marks columellae; 5. equatorial view, colpus; 6-10. equatorial view, mesocolpium (scale bar $10 \mu \mathrm{m} ; 1,3,5,7,9,10$ acetolyzed, 2, 4, 6, 8 stained with fuchsine); 11-15. SEM micrographs: 11. polar view; 12. equatorial view, pollen with slit-like colpus (arrow); 13. equatorial view, mesocolpium (scale bar $10 \mu \mathrm{m}) ; \mathbf{1 4}$, 15. ornamentation, arrows in 15 indicate laterally fused verrucae (scale bar $1 \mu \mathrm{m})$

with wavy margins and pointed ends, sometimes with geniculum; colpus length $2 / 3-4 / 5$ of polar axis; apocolpium diameter 7.2-7.9 $\mu \mathrm{m}$, mesocolpium width 14.2-16.5 $\mu \mathrm{m}$. Pores usually oblong. Exine thickness 1.6-1.8 $\mu \mathrm{m}$, columellae separate, thick; lens-shaped onci occur beneath apertures (Pl. 10, fig. 1). Exine ornamentation verrucate (LM); with SEM, ornamentation punctate-granulate-verrucate; puncta numerous; granula arranged on tectum between verrucae; verrucae almost uniform in size, rounded, sometimes solitary, but mainly located in small groups, fused laterally.

Re marks. Valdes et al. (1987) placed this species in type $Q$. suber, which can be described as 3-zonocolp-porate(3-colporoidate) with granulate-verrucate ornamentation. Denk and Grimm (2009) consigned it to the infrageneric group Quercus, with a verrucate type of ornamentation.

\section{Section Cerris \\ Subsect. Cerris}

\section{Q. castaneifolia C.A.Mey.}

Pl. 11

Description. Pollen grains 3-zonocolp-poroidate, sometimes 3-zonocolp-porate, from broadly oblong to widely ellipsoidal, outline in polar view rounded-triangular; polar axis 
22.0-31.3 $\mu \mathrm{m}$, equatorial diameter 21.2$30.7 \mu \mathrm{m}$. Colpi often without geniculum, not wide or narrow, with wavy margins and usually pointed ends; colpus length $\sim 4 / 5$ of polar axis; apocolpium diameter $8.3-10.0 \mu \mathrm{m}$, mesocolpium width $18.3-23.1 \mu \mathrm{m}$. Pores weakly expressed or clearly defined, usually oblong. Exine thickness 1.6-1.8 $\mu \mathrm{m}$, columellae separate; lens-shaped onci occur beneath apertures (Pl. 11, figs 2, 3). Exine ornamentation granulate (LM); ornamentation under SEM punctateverrucate; puncta rounded, sometimes elongate, rare $(Q$. castaneifolia-1) or numerous (Q. castaneifolia-2); verrucae rounded, densely arranged, usually in small groups, fused laterally.

Remarks. For this species, Monoszon (1954) and Kuprianova (1965) noted quite large
(35-37 $\mu \mathrm{m}$ ), 3-(sometimes 4)colp-porate pollen grains with thick exine $(2.3-2.8 \mu \mathrm{m})$, and narrow colpi of medium length. Denk and Grimm (2009) placed it (together with $Q$. cerris and $Q$. brantii) in the infrageneric group Cerris, with scattered verrucate ornamentation and verrucae "being simple tuft agglomerations" (Denk and Grimm, 2009: 931).

\section{Q. cerris L.}

Pl. 12

Description. Pollen grains 3-zonocolp-poroidate or 3-zonocolp-porate, oblate-spheroidal, sometimes spheroidal, outline in polar view rounded-triangular; polar axis 22.5-26.7 $\mu \mathrm{m}$, equatorial diameter 27.6-33.5 $\mu \mathrm{m}$. Colpi usually without geniculum, mostly not wide, with clearly defined, slightly wavy margins and
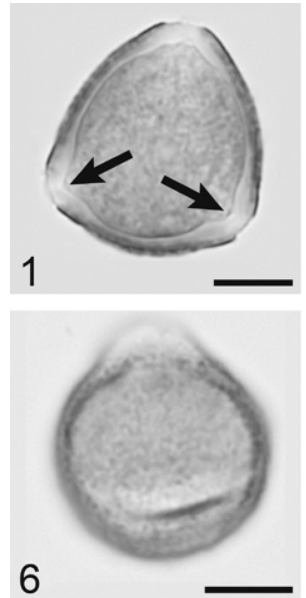

2
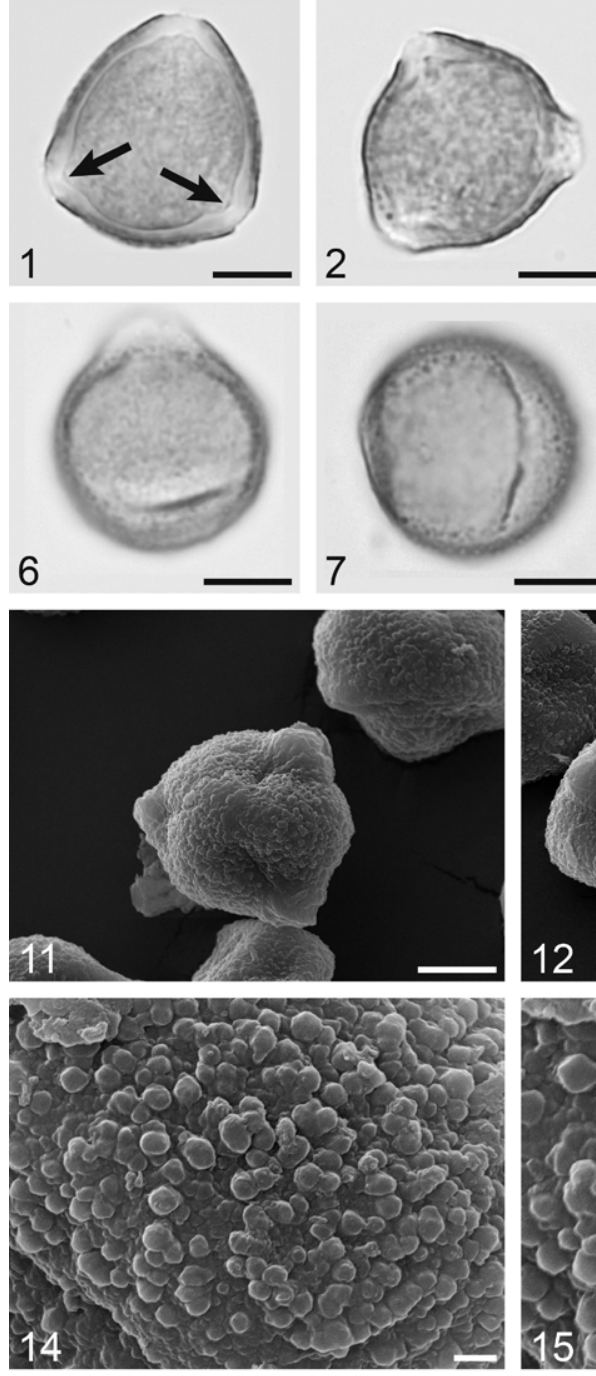
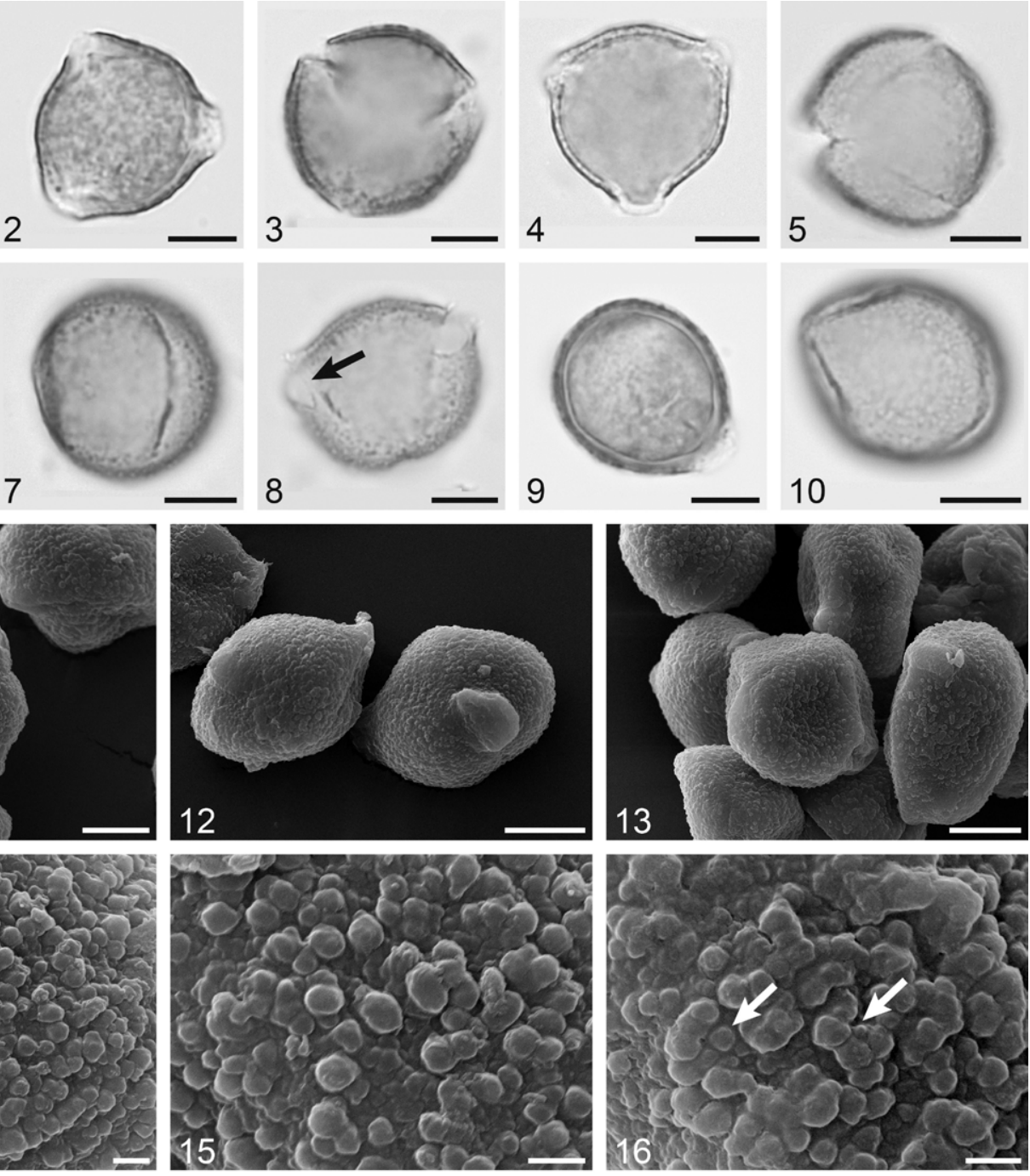

Plate 10. Pollen grains of Quercus faginea. 1-10. LM micrographs: 1-5. polar view, arrows in 1 indicate onci; 6-10. equatorial view, arrow in 8 indicates pore (scale bar $10 \mu \mathrm{m} ; 3,5,7-10$ acetolyzed, 1, 2, 4, 6 stained with fuchsine); 11-16. SEM micrographs: 11. polar view; 12. equatorial view, colpus; 13. equatorial view, mesocolpium (scale bar $10 \mu \mathrm{m}$ ); 14-16. ornamentation, arrows in 16 indicate solitary and laterally fused verrucae (scale bar $1 \mu \mathrm{m}$ ) 

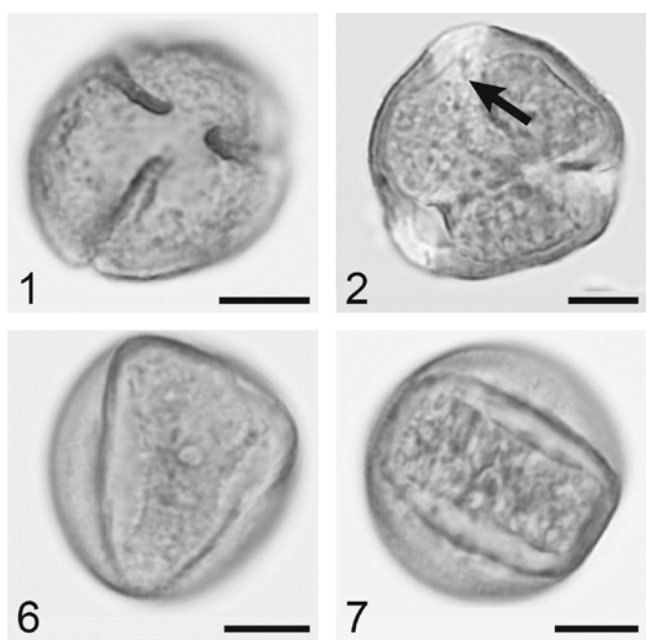

7
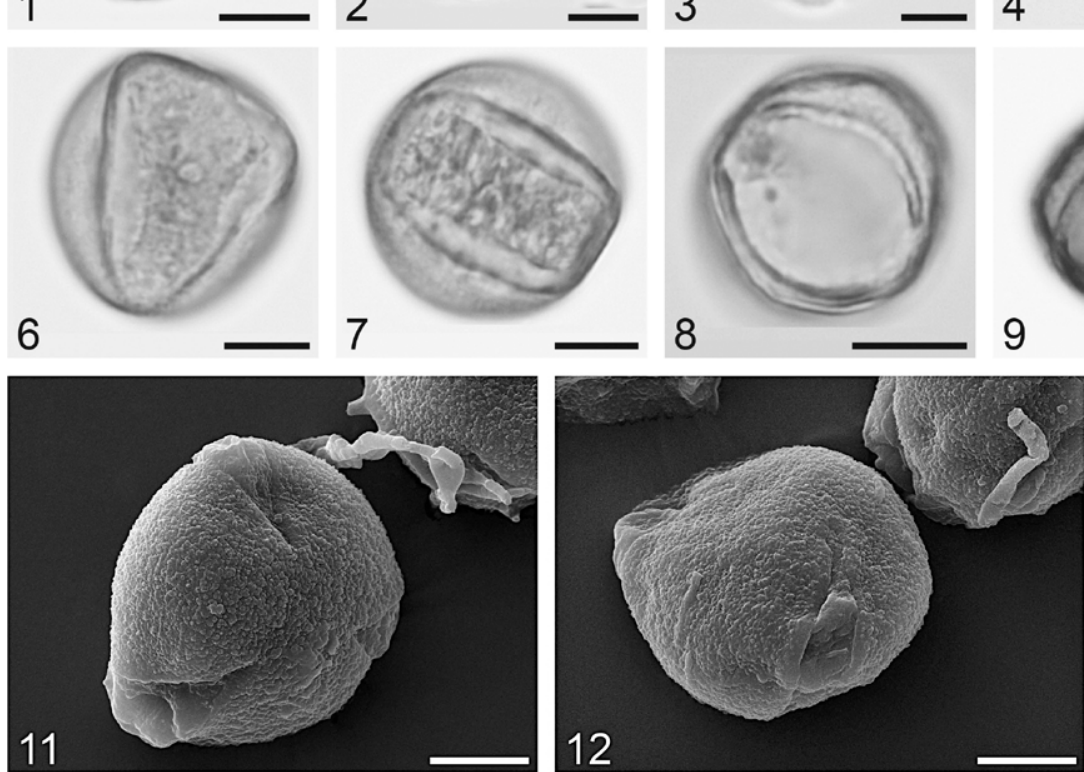
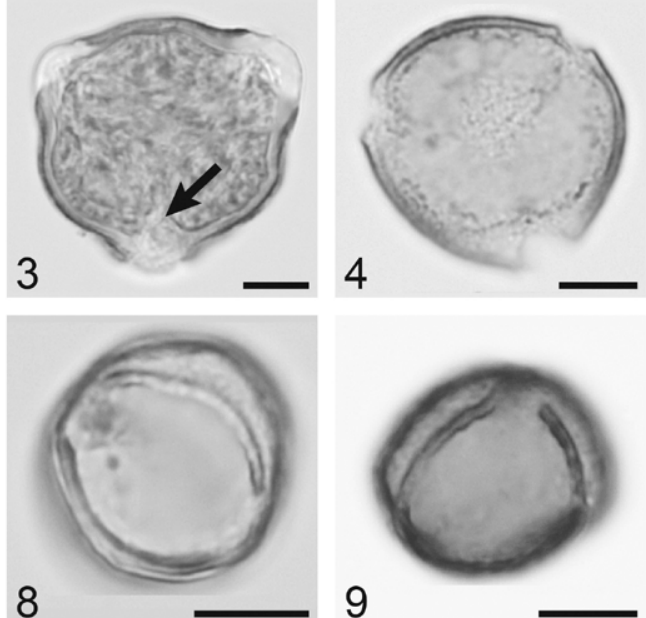

5
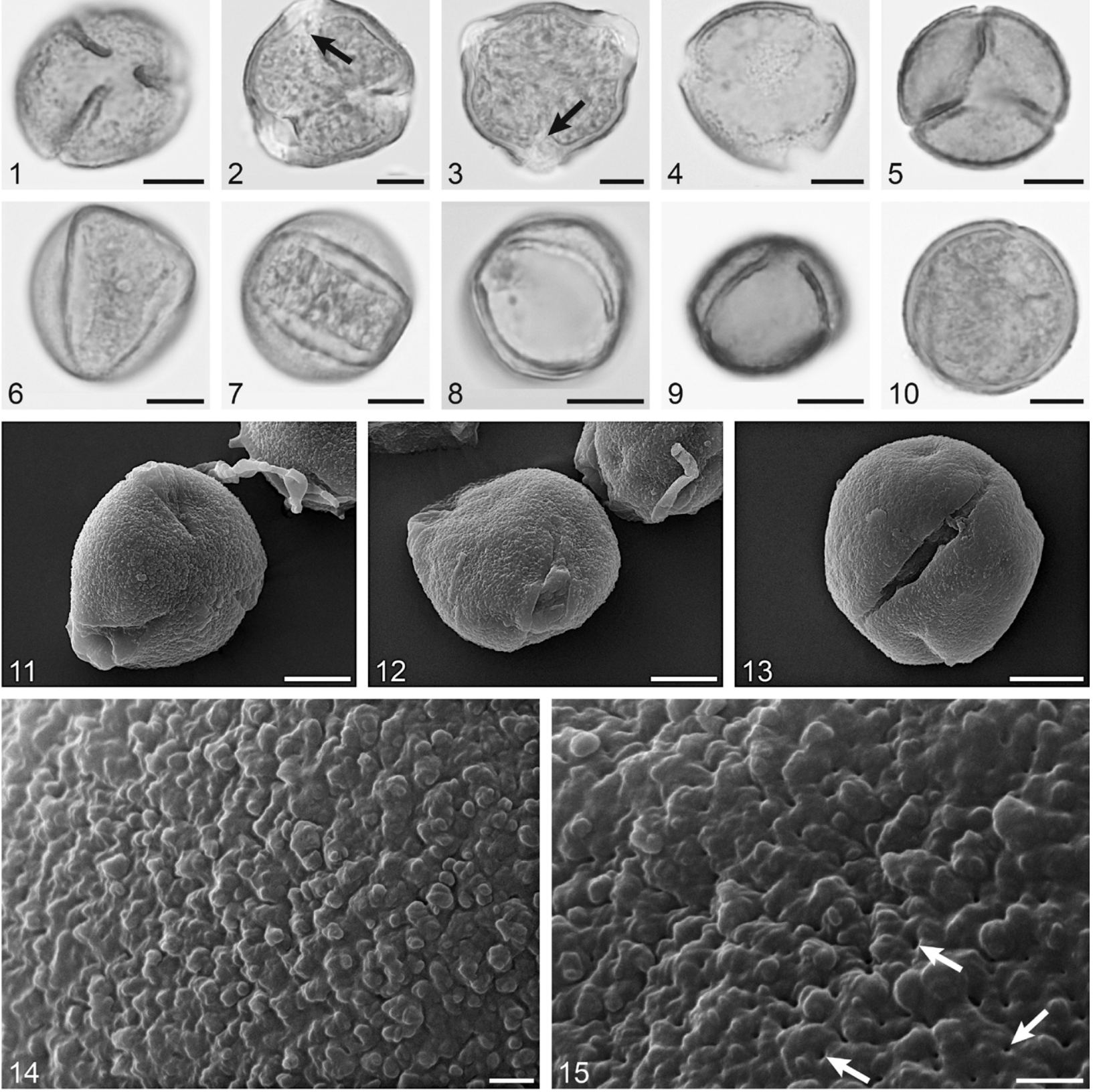

Plate 11. Pollen grains of Quercus castaneifolia (specimen 2). 1-10. LM micrographs: 1-5. polar view, arrows in 2 and 3 indicate onci; 6-10. equatorial view (scale bar $10 \mu \mathrm{m} ; 1,4-8,10$ acetolyzed, 2, 3, 9 stained with fuchsine); 11-15. SEM micrographs: 11. semipolar view; 12, 13. equatorial view (scale bar $10 \mu \mathrm{m}$ ); 14, 15. ornamentation, with numerous puncta in 15 (arrows) (scale bar $1 \mu \mathrm{m}$ )

pointed ends; colpus length $\sim 4 / 5$ of polar axis; apocolpium diameter 7.3-12.2 $\mu \mathrm{m}$, mesocolpium width 17.1-23.1 $\mu \mathrm{m}$. Pores weakly expressed or clearly defined, usually elongated. Exine thin, $1.2-1.4 \mu \mathrm{m}$, endexine slightly visible only in aperture areas; lens-shaped onci occur beneath apertures (Pl. 12, fig. 1). Exine ornamentation shows spherical or slightly elongated densely arranged outgrowths (LM); ornamentation under SEM punctate-granulate-verrucate, verrucae densely (Q. cerris-1) or infrequently $(Q$. cerris-3) distributed and varying in size $(0.3-0.8 \mu \mathrm{m})$, rounded (Q.cerris-1) or elongated (Q. cerris-3), usually in small groups, fused laterally, sometimes solitary. This type of ornamentation was found in two investigated samples of this species (Q. cerris-1 and Q. cerris-3).

Exine ornamentation of pollen from sample $Q$. cerris-2 is punctate-microrugulate (like $Q$. ilex and $Q$. coccifera from subgenus Heterobalanus), rugulae irregular arranged, sometimes fused laterally, forming spine-like excrescences. Most probably the herbarium specimen was wrongly determined. Therefore this sample will not be considered further in this study. 
Remarks. Smit (1973) placed Q. cerris and Q. suber in type C (Quercus suber), intermediate between type $\mathrm{A}$ and type $\mathrm{B}$, with colporate apertures and ornamentation "combines rounded, elliptic and elongated elements of varying shape and size". Following him, Van Benthem et al. (1984) wrote that this species takes an intermediate place between the micro-rugulate (i.e. $Q$. ilex) and scabrate-verrucate (i.e. $Q$. robur, $Q$. petraea, $Q$. pubescens) types of ornamentation due to small, densely packed sculptural elements, with longitudinal grooves. Colombo et al. (1983) noted that the structural elements of the exine may vary in shape and size from round to elongate. Denk and Grimm (2009) placed this species (with $Q$. castaneifolia and $Q$. brantii) in the infrageneric group Cerris (see comments for Q. castaneifolia).
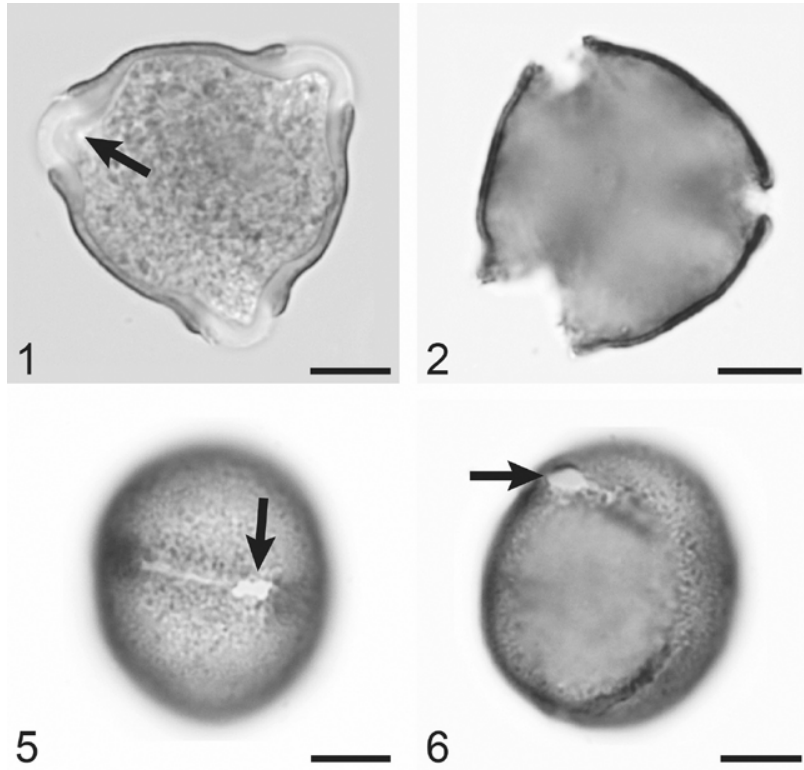

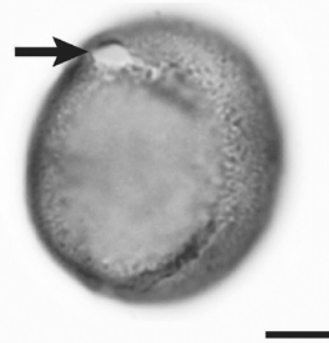

3

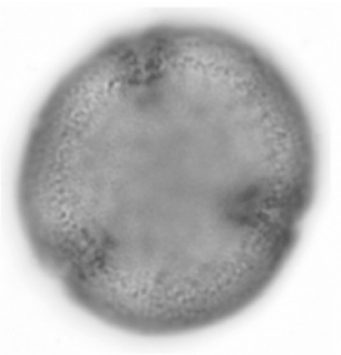

4

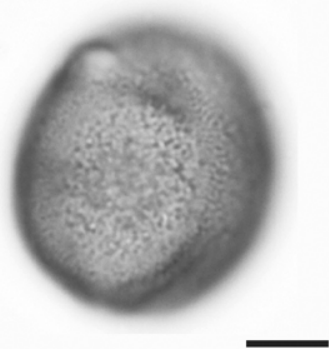

8

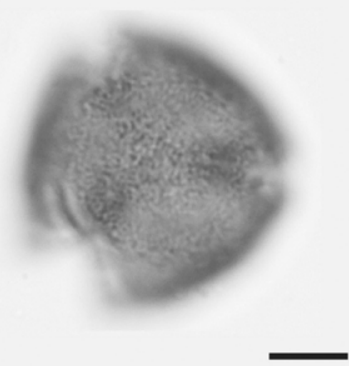

7
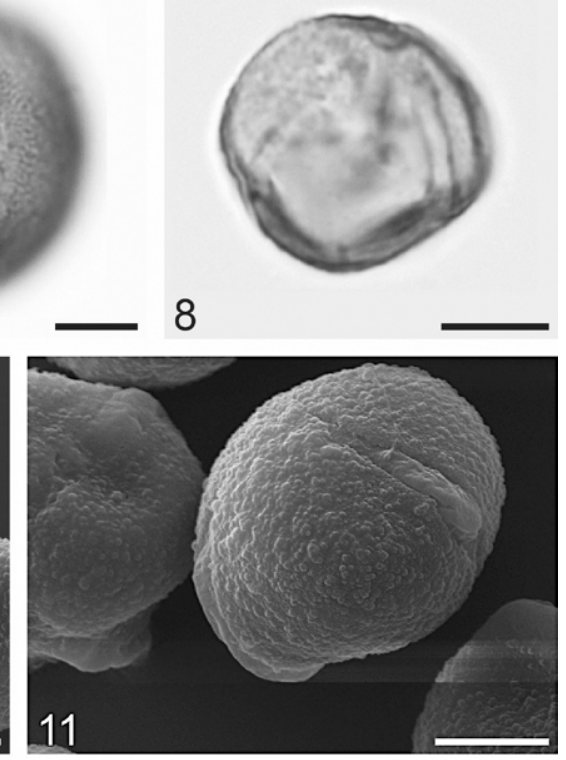
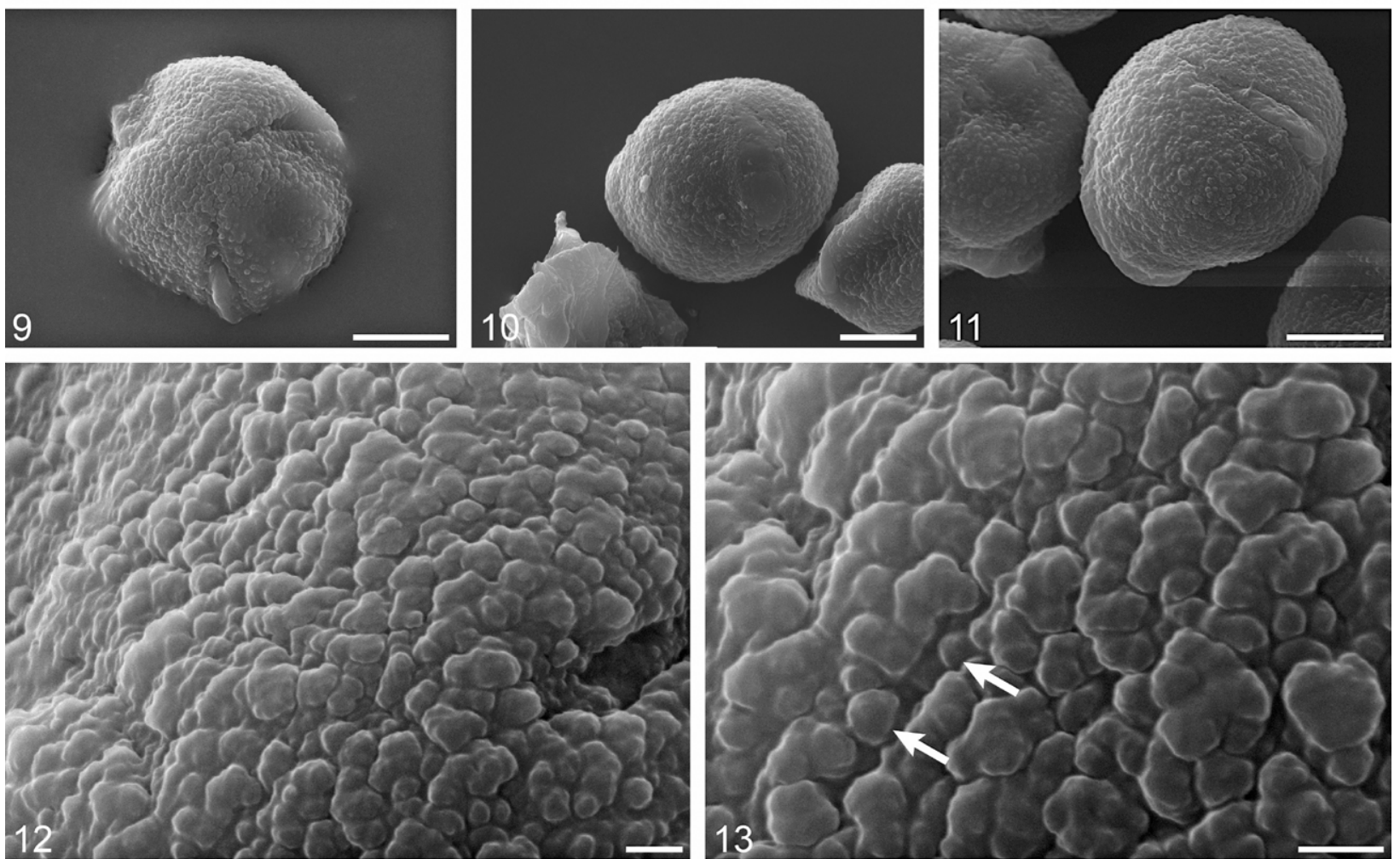

Plate 12. Pollen grains of Quercus cerris (specimen 1). 1-8. LM micrographs: 1-4. polar view, arrow in 1 indicates oncus; $\mathbf{5}$. equatorial view, colpus; 6-8. equatorial view, mesocolpium, arrows in 5 and 6 indicate pores (scale bar $10 \mu$ m; $2-8$ acetolyzed, 1 stained with fuchsine); 9-13. SEM micrographs: 9. polar view; 10. equatorial view, colpus; 11. equatorial view, mesocolpium (scale bar $10 \mu \mathrm{m}) ; \mathbf{1 2}$, 13. ornamentation, arrows in 13 indicate verrucae of various sizes (scale bar $1 \mu \mathrm{m}$ ) 
Subsect. Aegilops

Q. brantii Lindl.

Pl. 13

Description. Pollen grains 3-zonocolp-poroidate, sometimes 3-zonocolp-porate, usually oblong, sometimes spheroidal or oblate-spheroi- dal, outline in polar view rounded-triangular; polar axis 18.6-32.2 $\mu \mathrm{m}$, equatorial diameter 14.3-26.8 $\mu \mathrm{m}$. Colpi not wide, with slightly undulated margins and needle-like pointed ends, sometimes geniculate; colpus length $2 / 3-$ $4 / 5$ of polar axis; apocolpium diameter 8.4$10.1 \mu \mathrm{m}$, mesocolpium width 10.1-18.6 $\mu \mathrm{m}$. Pores weakly expressed or clearly defined,
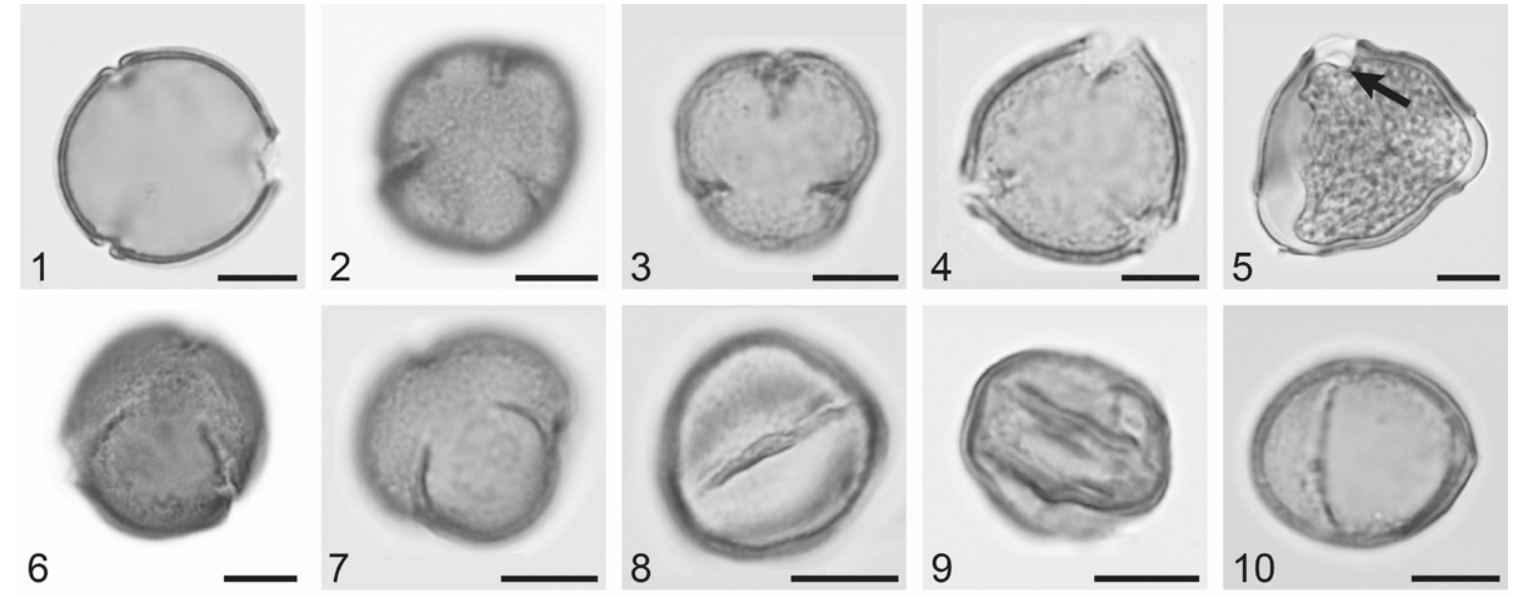

(n)
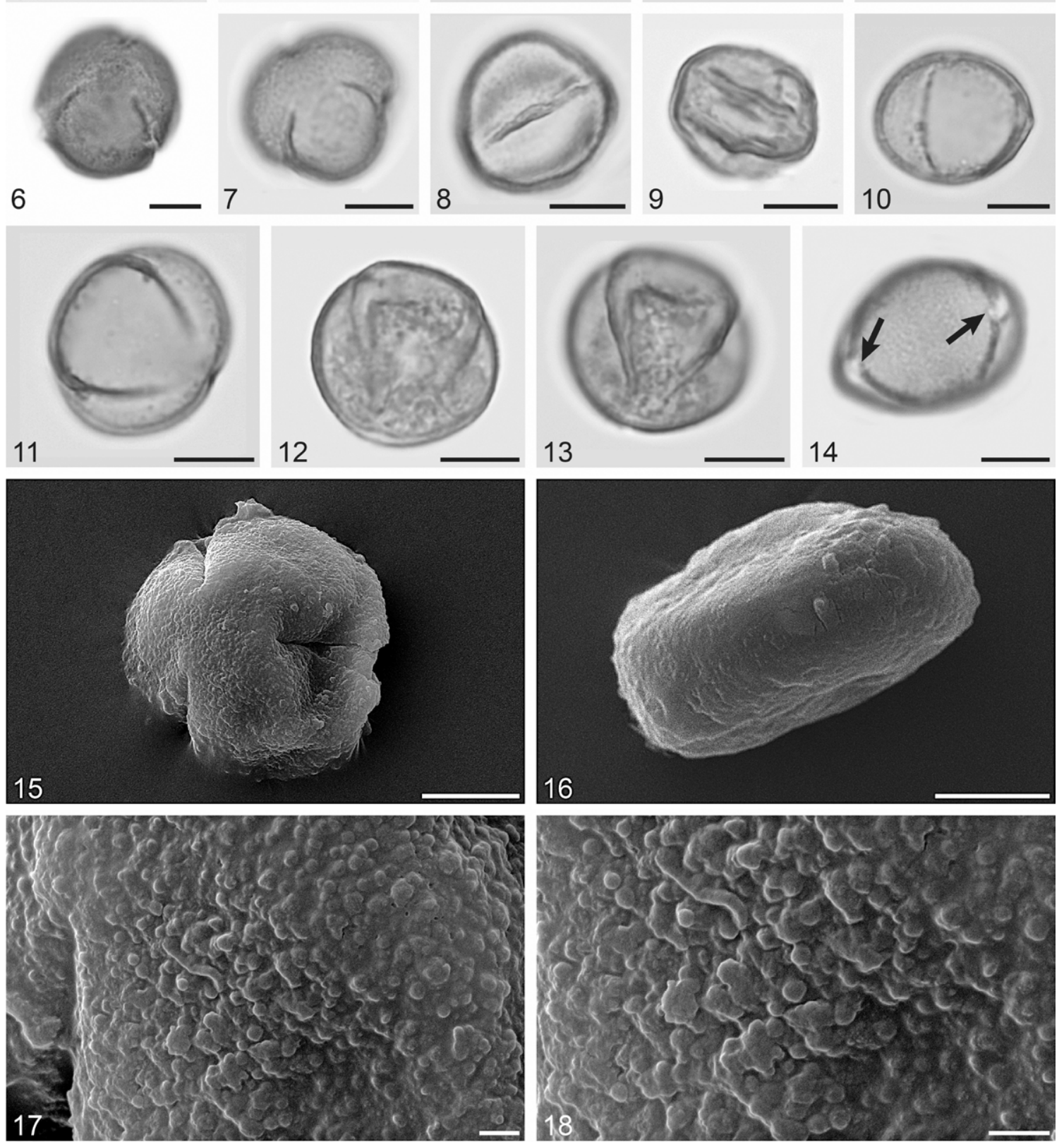

Plate 13. Pollen grains of Quercus brantii. 1-14. LM micrographs: 1-7. polar view, arrow in 5 indicates oncus; 8-14. equatorial view, arrows in 14 indicate pores (scale bar $10 \mu \mathrm{m} ; 1,4,7-14$ acetolyzed, 2, 3, 5, 6 stained with fuchsine); 15-18. SEM micrographs: 15. polar view; 16. equatorial view, mesocolpium (scale bar $10 \mu \mathrm{m}$ ); 17, 18. ornamentation (scale bar $1 \mu \mathrm{m}$ ) 
usually elongated. Exine thin, 1.2-1.3 $\mu \mathrm{m}$, columellae thick and separate; lens-shaped onci occur beneath apertures. Exine ornamentation finely verrucate (LM); with SEM, ornamentation punctate-granulate-verrucate; puncta rounded, sometimes elongated; granula arranged on tectum between verrucae; verrucae (or microverrucae) densely arranged and varying in size, usually elongated, sometimes fused laterally.

Remarks. Denk and Grimm (2009) placed this species in the infrageneric group Cerris, with scattered verrucate ornamentation and verrucae 'being simple tuft agglomerations' (Denk and Grimm, 2009) (see also remarks on Q. castaneifolia).
Q. persica Jaub. et Spach

Pl. 14

Description. Pollen grains 3-zonocolpate or 3-zonocolp-poroidate, mostly angular-spheroidal, outline in polar view rounded-triangular; polar axis 18.2-27.8 $\mu \mathrm{m}$, equatorial diameter 17.5-29.4 $\mu \mathrm{m}$. Colpi not always clearly defined, not wide, with slightly wavy (sometimes parallel) margins and pointed ends; colpus length 2/3-4/5 of polar axis; apocolpium diameter 12.5$16.9 \mu \mathrm{m}$, mesocolpium width 18.7-21.1 $\mu \mathrm{m}$. Pores absent or weakly expressed. Exine thickness 1.3-1.4 $\mu \mathrm{m}$, endexine very weakly expressed. Exine ornamentation finely verrucate (LM); ornamentation under SEM punctate-granulate-verrucate; granula arranged on tectum between verrucae; verrucae (or microverrucae)
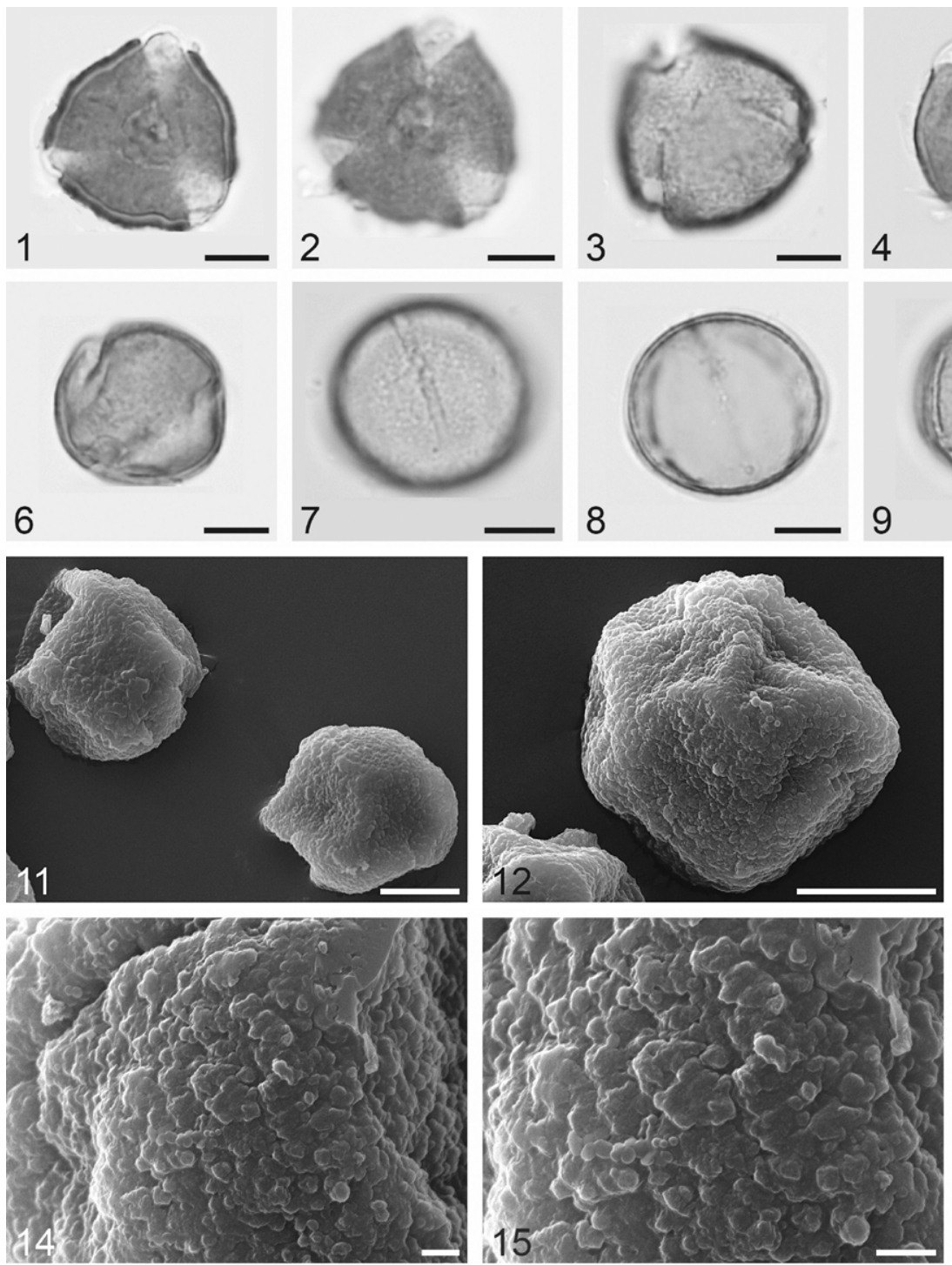
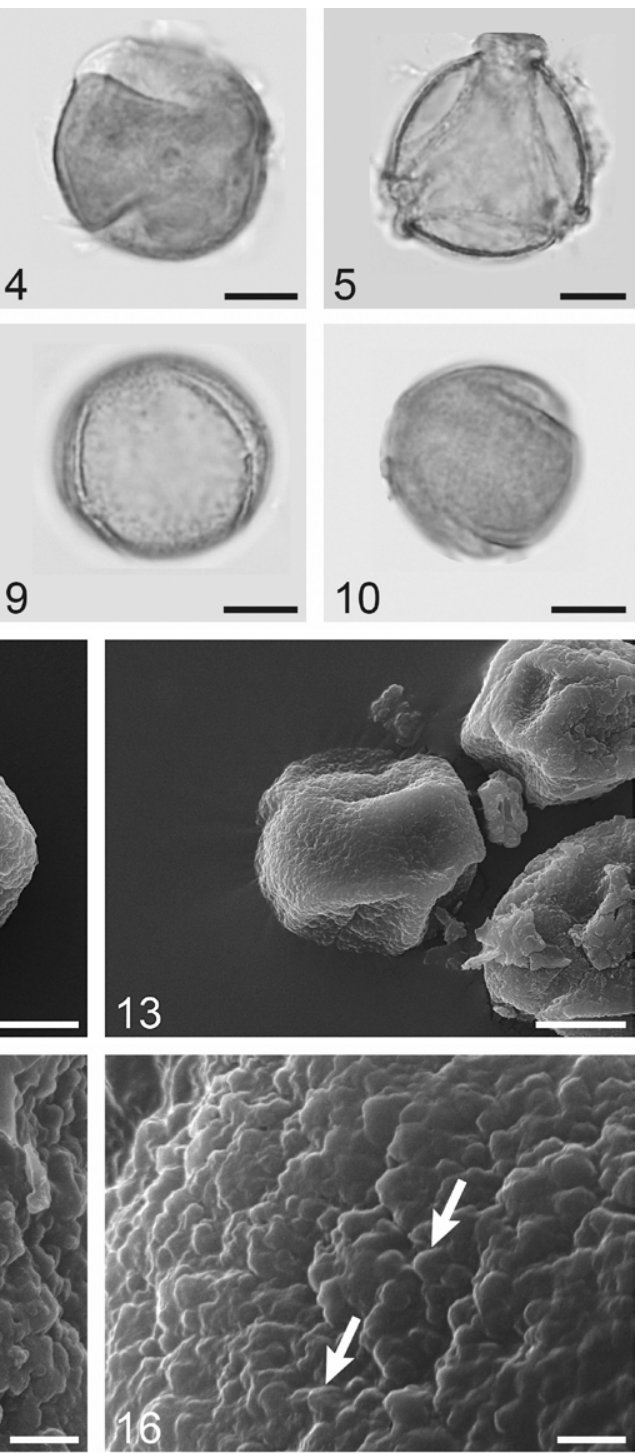

Plate 14. Pollen grains of Quercus persica. 1-10. LM micrographs: 1-6. polar view; 7. equatorial view, colpus; 8-10. equatorial view, mesocolpium (scale bar $10 \mu \mathrm{m} ; 3-10$ acetolyzed, 1, 2 stained with fuchsine); 11-16. SEM micrographs: 11-13. mesocolpium (scale bar $10 \mu \mathrm{m}$ ); 14-16. ornamentation, arrows in 16 indicate conically elongated verrucae (scale bar $1 \mu \mathrm{m}$ ) 
irregularly arranged, conically elongated, varying in size, sometimes fused laterally.

Remarks. Along with significant similarity in pollen characteristics, the main difference between the investigated specimens of $Q$. brantii and $Q$. persica (accepted as synonym of $Q$. brantii, see Tab. 1 ) is that $Q$. brantii is characterized by more highly specialized complex 3-zonocolp-poroidate, sometimes 3-zonocolpporate apertures, while the pores in pollen of $Q$. persica are either weakly expressed (3-zonocolp-poroidate) or absent (3-zonocolpate). See also remarks on $Q$. brantii.

\section{Q. aegilops L.}

Pl. 15

Description. Pollen grains 3-zonocolpate, 3-zonocolp-poroidate, rarely 3-zonocolp-porate, oblong or spheroidal, outline in polar view triangular or rounded-triangular; polar axis 23.6$32.8 \mu \mathrm{m}$, equatorial diameter 21.0-28.2 $\mu \mathrm{m}$. Colpi usually geniculate, not wide, sometimes almost slit, with straight or slightly wavy margins and rounded or pointed ends; colpus length $2 / 3-3 / 4$ of polar axis; apocolpium diameter 8.1-10.2 $\mu \mathrm{m}$, mesocolpium width 14.2-20.3 $\mu \mathrm{m}$. Pores, if present, weakly expressed, rarely
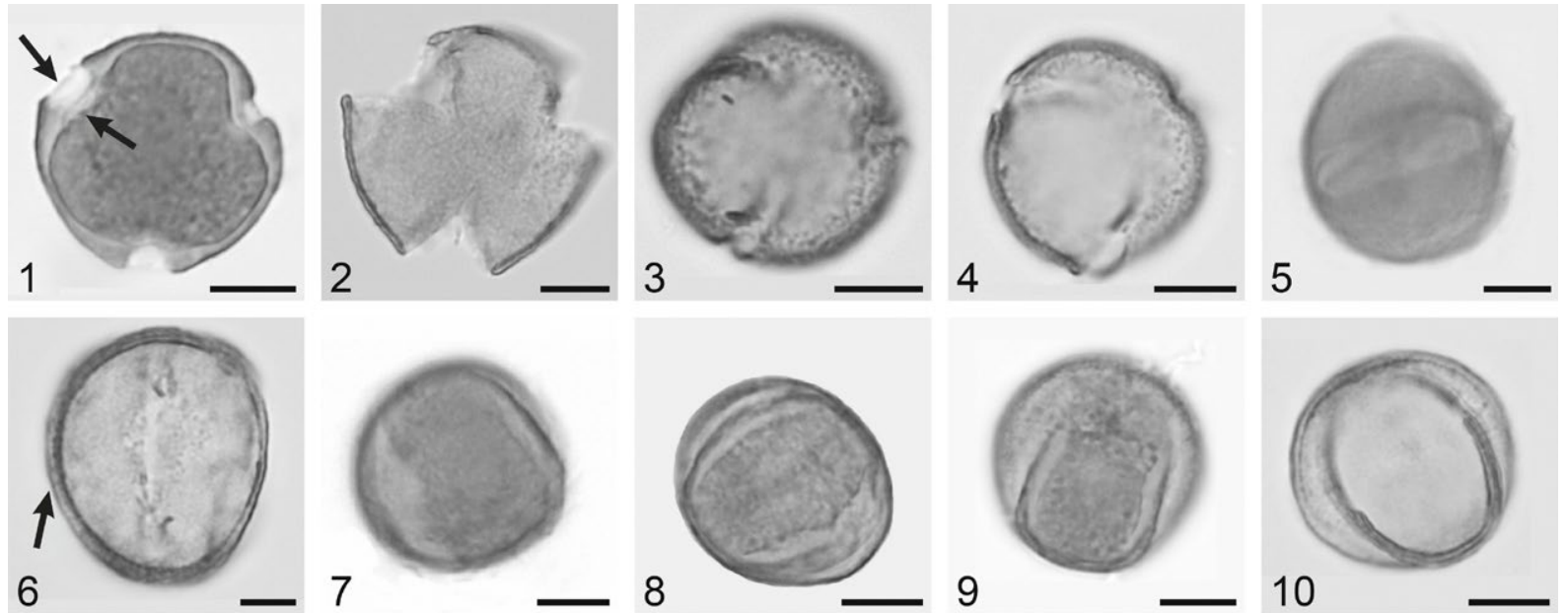

7
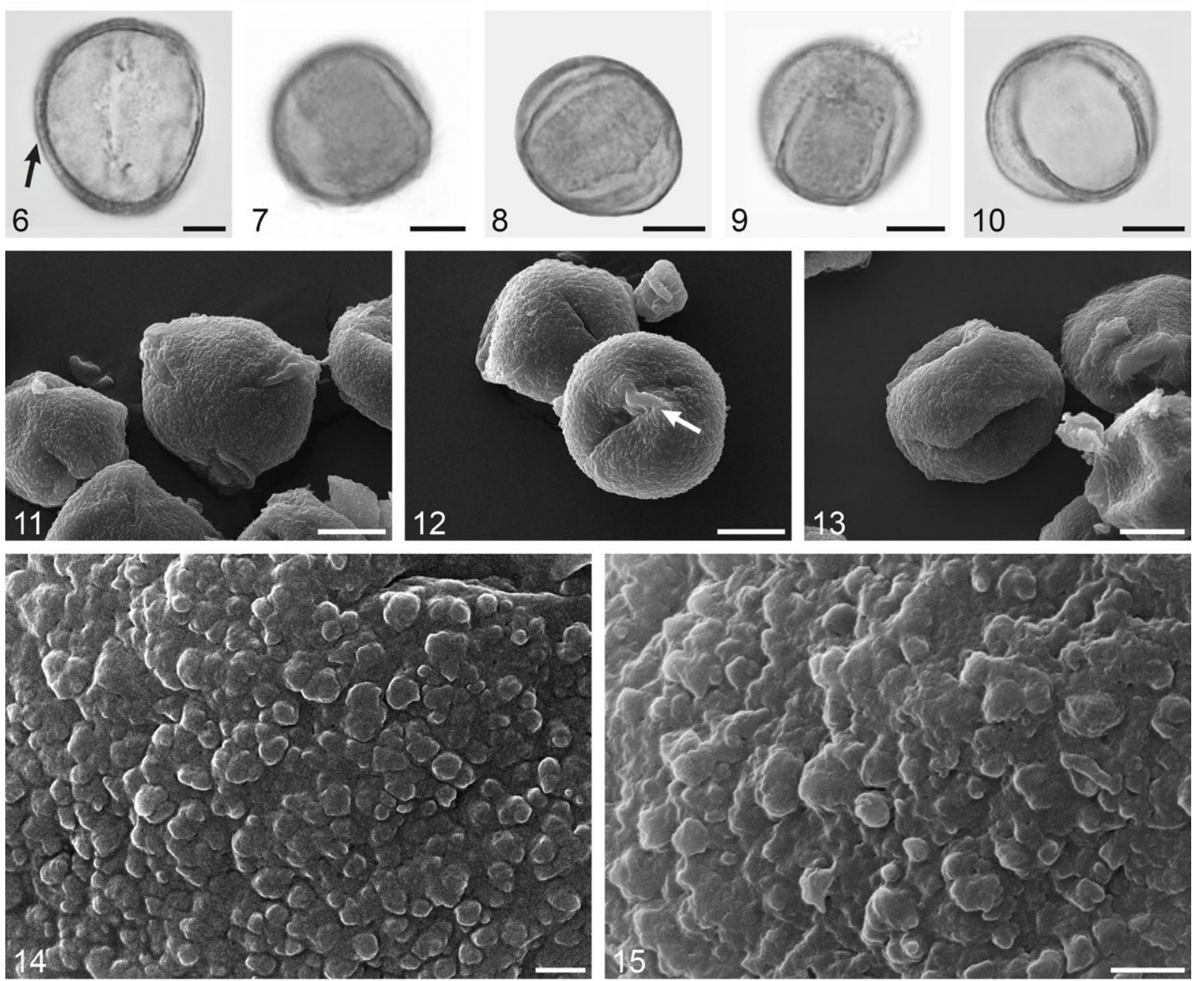

Plate 15. Pollen grains of Quercus aegilops. 1-10. LM micrographs: 1-4. polar view, arrows in 1 indicate pore and oncus, 5, 6. equatorial view, colpus, arrow in 6 indicates columellae; 7-10. equatorial view, mesocolpium (scale bar $10 \mu m ; 2-4$, 6, 9, 10 acetolyzed, 1, 5, 7, 8 stained with fuchsine); 11-15. SEM micrographs: 11. polar view; 12. equatorial view, colpus with geniculum (arrow); 13. equatorial view, mesocolpium (scale bar $10 \mu \mathrm{m}$ ); 14, 15. ornamentation (scale bar $1 \mu \mathrm{m}$ ) 
clearly defined, usually elongated. Exine thickness $1.3-1.4 \mu \mathrm{m}$, columellae thin and separate (Pl. 15, fig. 6); lens-shaped onci occur beneath apertures (Pl. 15, fig. 1). Exine ornamentation verrucate (LM); with SEM, ornamentation punctate-granulate-microverrucate; puncta rounded, sometimes elongate; granula arranged on tectum between verrucae; verrucae solitary and of variable size $(0.3-0.5 \mu \mathrm{m})$, rounded or elongate, sometimes located in small groups, merging laterally.

Re m arks. Denk and Grimm (2009) and Denk and Tekleva (2014) put this species (as Q. ithaburensis subsp. macrolepis) in the group Cerris, with a type 2 foot layer, which is irregular, discontinuous and comparatively thin.

\section{Subgenus Heterobalanus}

Section Heterobalanus

Subsect. Heterobalanus

Q. alnifolia Poech.

Pl. 16

Description. Pollen grains 3-zonocolpporoidate, rarely 3-zonocolp-porate, oblong to oblate-spheroidal, outline in polar view rounded-3-lobed; polar axis 15.7-20.3 $\mu \mathrm{m}$, equatorial diameter 15.2-23.5 $\mu \mathrm{m}$. Colpi usually geniculate, narrow, sometimes almost slitlike, with clearly defined margins and pointed ends; colpus length $3 / 4-5 / 6$ of polar axis;
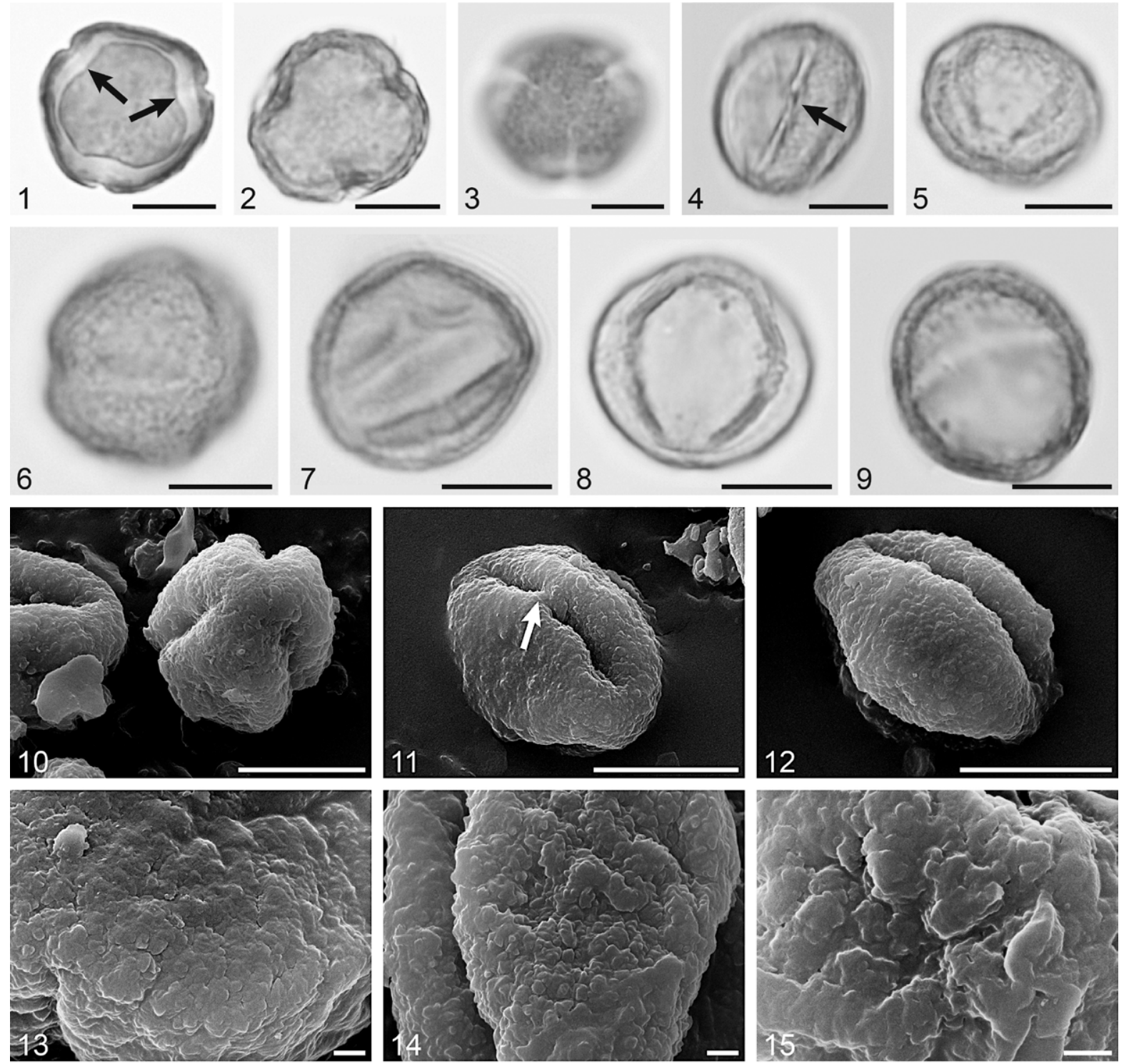

Plate 16. Pollen grains of Quercus alnifolia. 1-9. LM micrographs: 1-3. polar view, arrows in 1 indicate onci; 4. equatorial view, colpus, small geniculum (arrow); 5-9. equatorial view, mesocolpium (scale bar 10 $\mu$; 4-9 acetolyzed, 1-3 stained with fuchsine); 10-15. SEM micrographs: 10. polar view; 11, 12. equatorial view, mesocolpium, arrow in 11 indicates small geniculum (scale bar $10 \mu \mathrm{m})$; 13-15. ornamentation (scale bar $1 \mu \mathrm{m}$ ) 
apocolpium diameter 4.5-7.7 $\mu \mathrm{m}$, mesocolpium width 12.2-15.1 $\mu \mathrm{m}$. Pores very often poorly expressed, circular. Exine thickness 1.2$1.4 \mu \mathrm{m}$, columellae thin, separate; lens-shaped onci occur beneath apertures (Pl. 16, fig. 1). Exine ornamentation finely verrucate (LM); within a single sample, ornamentation under SEM varies from punctate-microverrucate to punctate-verrucate-tuberculate, sometimes punctate-verrucate-rugulate; puncta sparsely arranged, rounded, sometimes elongate; verrucae solitary and of variable size $(0.3-0.8 \mu \mathrm{m})$, rounded or elongated.

Remarks. Denk and Grimm (2009) placed this species in the infrageneric group Ilex with rod-like microrugulate ornamentation.

\section{Subsect. Suber}

\section{Q. suber L.}

Pl. 17

De s c riptio n. Pollen grains 3-zonocolp-poroidate (3-zonocolp-porate), spheroidal or oblatespheroidal, outline in polar view rounded-triangular; polar axis 16.3-27.2 $\mathrm{mm}$, equatorial diameter 17.4-32.5 $\mu \mathrm{m}$. Colpi geniculate, not wide or narrow, almost slit-like, with slightly wavy margins and pointed ends; colpus length $2 / 3-3 / 4$ of polar axis; apocolpium diameter 7.4-10.4 $\mu \mathrm{m}$, mesocolpium width 16.0-20.1 $\mu \mathrm{m}$. Pores often poorly expressed, circular. Exine thickness 1.5-1.7 $\mu \mathrm{m}$, columellae separate; lens-shaped onci occur beneath apertures (Pl. 17, fig. 1). Exine ornamentation finely verrucate (LM); under SEM, ornamentation in all investigated samples punctate-granulate-verrucate, puncta numerous, rounded, sometimes elongate; verrucae varying in size $(0.3-0.8 \mu \mathrm{m})$, often elongate, sometimes in small groups, fused laterally.

Pollen of $Q$. suber-3 shows the presence of islets with secondary accumulated sporopollenin (Fig. 1h).

Rem arks. Samoilovich (1950) noted the presence of a thick exine, often wrinkled into irregular-shaped plicae. Smit (1973) placed this species in type C (Quercus suber). Colombo et al. (1983) showed that the structural elements of the exine vary in size and in shape from round to elongate. Valdes et al. (1987) described this species (together with $Q$. faginea and several others) as type $Q$. suber, characterized by a 3-zonocolp-porate (colp-poroidate) aperture type and granulate-verrucate ornamentation, with small subsculpture elements on granules as on verrucae. Denk and Grimm (2009), following Smit (1973) and Colombo et al. (1983), placed this species (with $Q$. cerris) in the infrageneric group Cerris, with scattered verrucate ornamentation and verrucae 'being simple tuft agglomerations' (Denk and Grimm, 2009: 931).

\section{Section Ilex}

Subsect. Ilex

\section{Q. ilex L.}

Pl. 18

Description. Pollen grains 3-zonocolpate, 3-zonocolp-poroidate, from oblong to oblatespheroidal, sometimes angular-rounded, outline in polar view rounded-3-lobed; polar axis 18.6-29.6 $\mu \mathrm{m}$, equatorial diameter 20.1$32.0 \mu \mathrm{m}$. Colpi almost slit-like, with even margins and pointed ends, often without geniculum; colpus length $3 / 4-4 / 5$ of polar axis; apocolpium diameter 7.3-10.2 $\mathrm{\mu m}$, mesocolpium width $14.3-17.1 \mu \mathrm{m}$. Pores often poorly expressed. Exine thickness $\sim 1.2-1.5 \mu \mathrm{m}$, columellae thick, separate, regularly arranged. Exine ornamentation 'spinulose' (LM); ornamentation under SEM punctate-microrugulate, puncta numerous; rugulae irregularly arranged, sometimes fused laterally, forming spine-like excrescences.

Remarks. Monoszon (1954) and Kuprianova (1965) noted the presence of very long colpi and well-defined pores. Smit (1973) placed this species in type B (Quercus ilex/coccifera) with colporate apertures and with sculpture having scattered straight, hooked or curved elements. According to Colombo et al. (1983), pollen of $Q$. ilex and $Q$. coccifera do not present substantial differences in exine architecture; the morphology is characterized by dense, protruding rugulate elements in an irregular arrangement. Denk and Grimm (2009) placed this species in the infrageneric group Ilex with rod-like microrugulate ornamentation. The same type of sculpture was also described by Van Benthem et al. (1984). 


\section{Subsect. Cocciferae}

\section{Q. coccifera $\mathrm{L}$.}

Pl. 19

Description. Pollen grains 3-zonocolp-poroidate, sometimes 3-zonocolp-porate, mostly oblong, outline in polar view rounded-triangular or 3-lobed; polar axis 17.4-23.1 $\mu \mathrm{m}$, equa- torial diameter 15.5-23.6 $\mu \mathrm{m}$. Colpi usually geniculate, rather narrow, sometimes almost slit-shaped, with even (sometimes slightly wavy), well-rounded margins and pointed needle-like ends; colpus length $3 / 4-4 / 5$ of polar axis; apocolpium diameter $4.3-6.2 \mu \mathrm{m}$, mesocolpium width $12.9-15.7 \mu \mathrm{m}$. Pores often weakly expressed, circular. Exine thickness 1.2-1.4 $\mathrm{\mu m}$, columellae thin, separate;

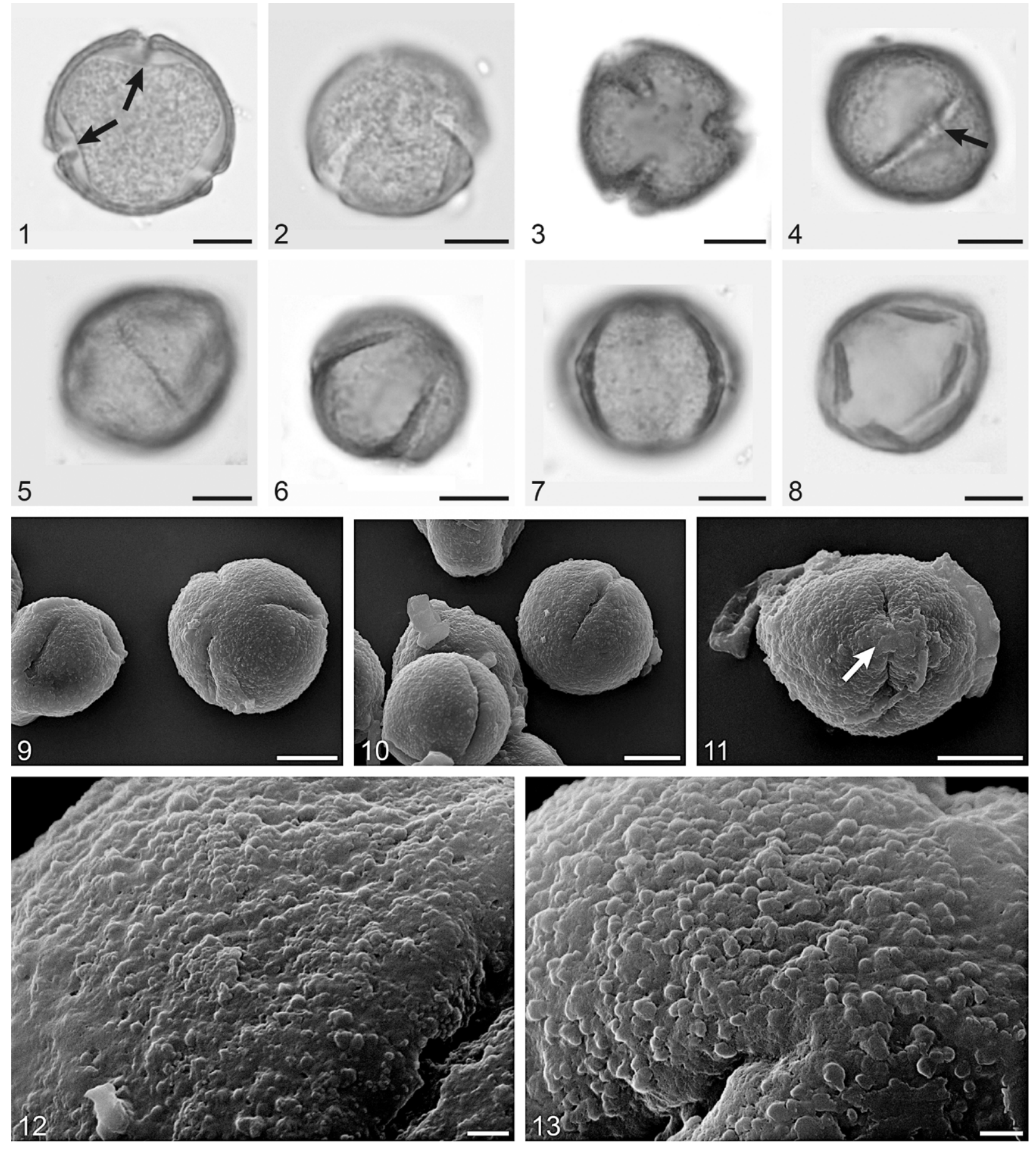

Plate 17. Pollen grains of Quercus suber (specimen 1). 1-8. LM micrographs: 1-3. polar view, arrows in 1 indicate onci; $\mathbf{4}, \mathbf{5}$. equatorial view, colpi, arrow in 4 indicate pore; 6-8. equatorial view, mesocolpium (scale bar $10 \mu \mathrm{m} ; 2,5-8$ acetolyzed, 1, 3, 4 stained with fuchsine); 9-13. SEM micrographs: 9, 10. pollen groups; 11. equatorial view, colpus with geniculum (arrow) (scale bar $10 \mu \mathrm{m}$ ); 12, 13. ornamentation (scale bar $1 \mu \mathrm{m}$ ) 
lens-shaped onci occur beneath apertures (Pl. 19, fig. 2). Exine ornamentation finely verrucate (LM); with SEM, ornamentation punctate-microrugulate, puncta numerous; rugulae irregularly arranged, few rugulae usually fuse laterally, forming spine-like excrescences.

Remarks. See remarks on $Q$. ilex.
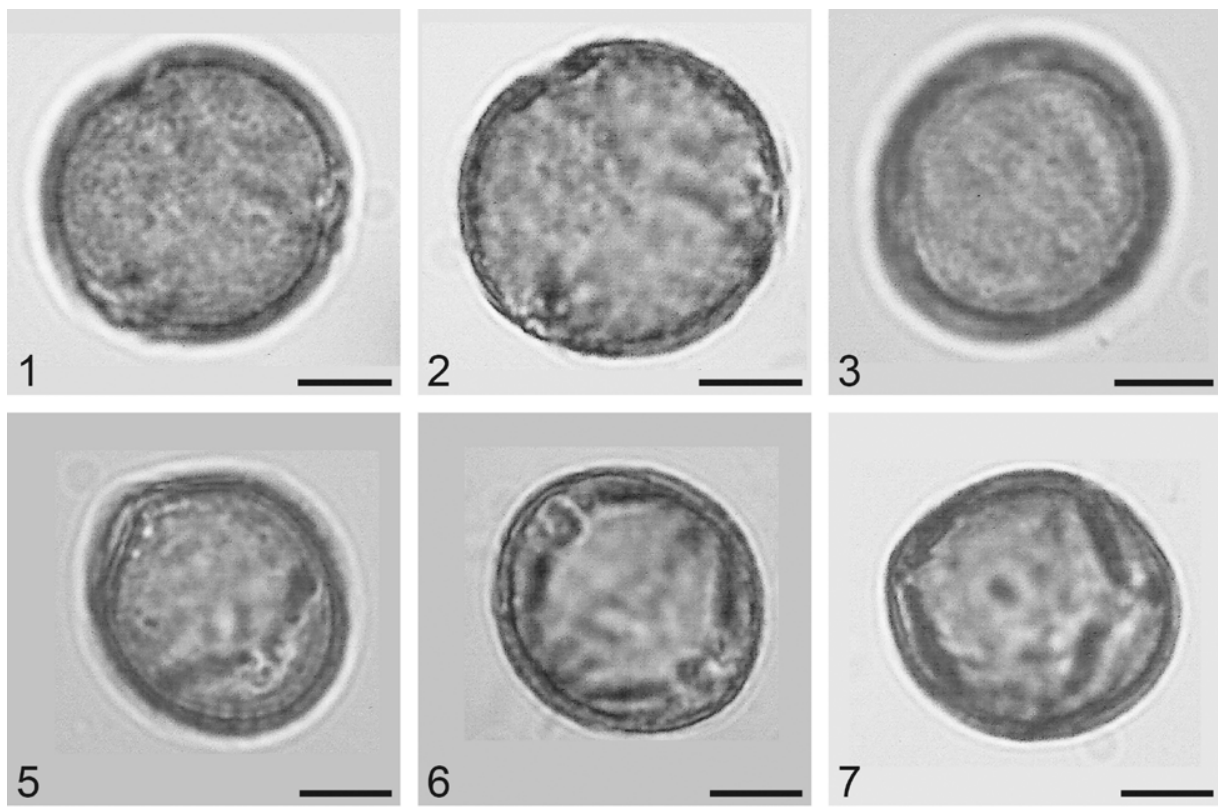

4
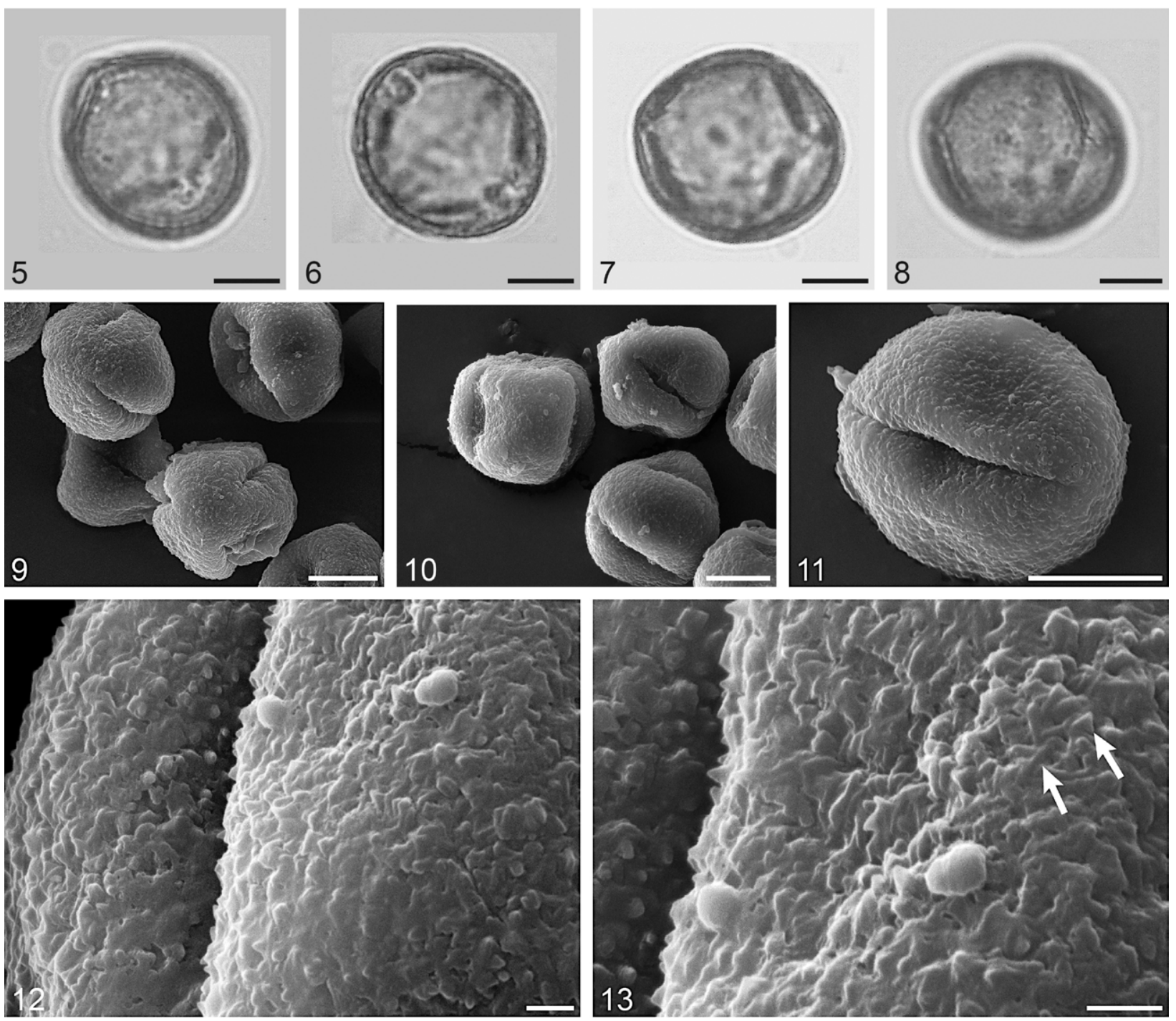

Plate 18. Pollen grains of Quercus ilex (specimen 1). 1-8. LM micrographs: 1, 2. polar view; 3, 4. equatorial view, colpi; 5-8. equatorial view, mesocolpium (scale bar $10 \mu \mathrm{m} ; 1,2,5-8$ acetolyzed, 3, 4 stained with fuchsine); 9-13. SEM micrographs: 9, 10. groups of pollen; 11. equatorial view, colpus (scale bar $10 \mu \mathrm{m}$ ); 12, 13. ornamentation, arrows in 13 indicate rugulae and spine-like excrescences (scale bar $1 \mu \mathrm{m}$ ) 

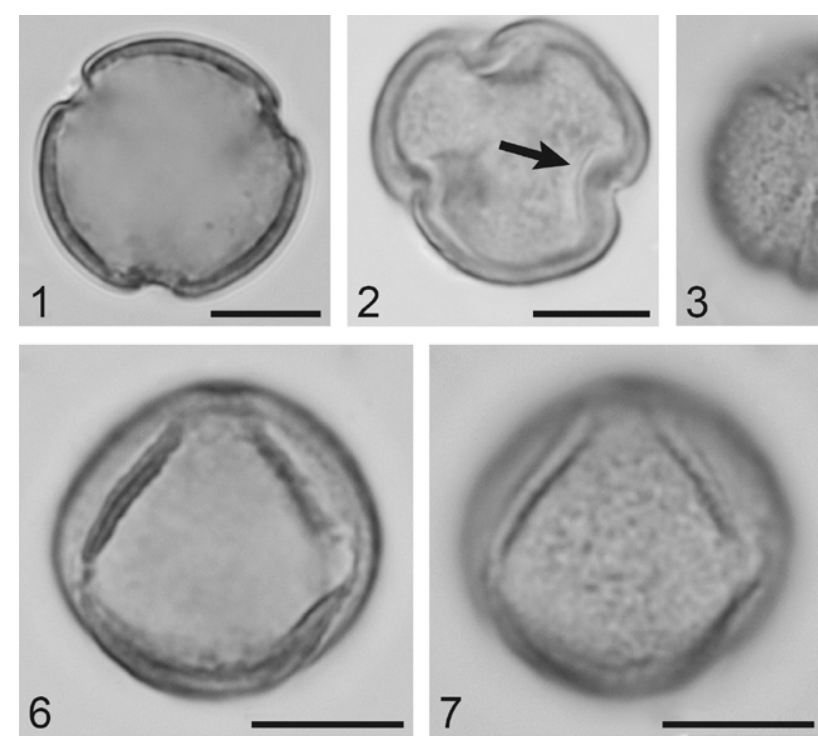

6
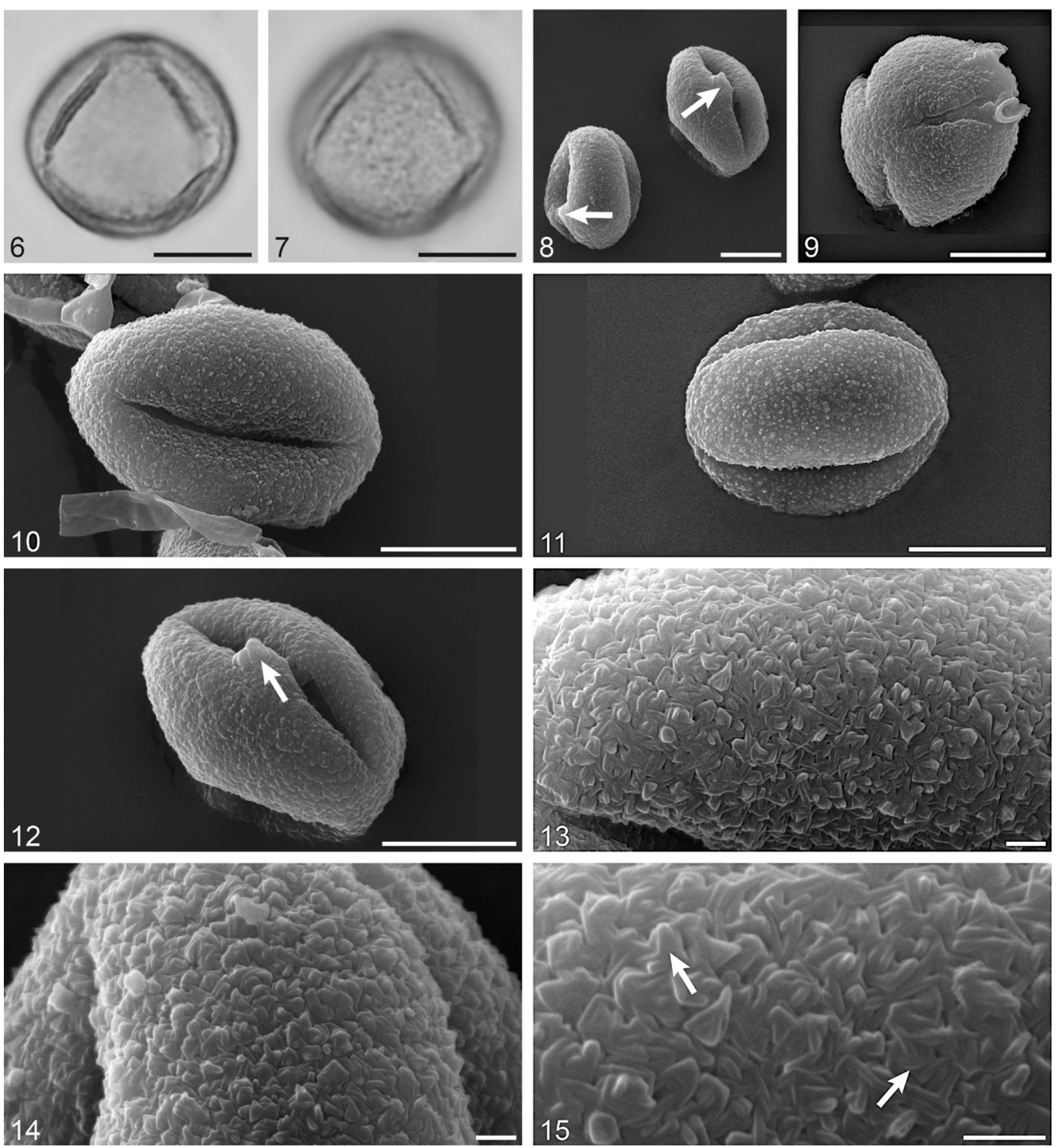

Plate 19. Pollen grains of Quercus coccifera (specimen 1). 1-7. LM micrographs: 1-3. polar view, arrow in 2 indicates oncus; 4. equatorial view, colpus; 5-7. equatorial view, mesocolpium (scale bar $10 \mu \mathrm{m} ; 1,3,6,7$ acetolyzed, 2, 4, 5 stained with fuchsine); 8-15. SEM micrographs: 8. group of pollen, genicula (arrows); 9. semipolar view; 10. equatorial view, colpus; 11, 12. equatorial view, mesocolpium, arrow in 12 indicates geniculum (scale bar $10 \mu \mathrm{m}$ ); 13-15. ornamentation, arrows in 15 indicate punctate-microrugulate ornamentation with spine-like excrescences (scale bar $1 \mu \mathrm{m}$ ) 


\section{RESULTS OF THE COMPARATIVE ANALYSIS}

Our comparative analysis of morphological characteristics of pollen from 19 investigated species of the genus Quercus, summarized in Table 3, revealed the following:

1. Two main types of apertures, 3-zonocolpate and 3-zonocolp-porate, were identified for the species studied. The pores were not always clearly visible; such apertures are characterized as 3-zonocolp-poroidate. According to the presence of clearly defined pores in the colpi, all investigated species of the genus Quercus merge into two main groups: (a) with pore areas poorly expressed or absent (pollen grains 3-zonocolpate or 3-zonocolp-poroidate), including $Q$. petraea, $Q$. iberica, $Q$. macranthera, $Q$. frainetto, Q. pubescens, Q. persica (subgen. Quercus) and Q. ilex (subgen. Heterobalanus; (b) with pore areas sometimes very well expressed (pollen grains 3-zonocolpate, 3-zonocolp-poroidate, sometimes 3-zonocolp-porate, usually lens-shaped onci occur beneath of such apertures), including $Q$. pontica, $Q$. robur, $Q$. dshorochensis, Q. araxina, Q. faginea, Q. castaneifolia, $Q$. cerris, $Q$. brantii, $Q$. aegilops (subgen. Quercus), Q. alnifolia, Q. suber and $Q$. coccifera (subgen. Heterobalanus).

2 . The shape of the pollen grains is roundedangular, oblate, oblong, oblong-spheroidal, spheroidal or ellipsoidal, and often varies considerably even within a single sample.

3. Pollen grains are small or medium-sized (according to Erdtman, 1952) and vary between 15.5 and $38.7 \mu \mathrm{m}$.

4. Another characteristic feature of pollen apertures of the genus Quercus is the presence of a geniculum, documented for the vast majority of investigated species.

5. Exine thickness varies from $0.7-1.0 \mu \mathrm{m}$ (Q. pontica) to 2.4-2.6 $\mu \mathrm{m}$ (Q. macranthera). The ectexine usually is thicker than the endexine. Columellae are usually separate, thin, sometimes thick, expanding at the end.

6. Exine ornamentation under LM usually seems to be verrucate, sometimes granulate (Q. castaneifolia) or 'spinulose' (Q. ilex); or the exine ornamentation shows spherical or slightly elongated, densely arranged outgrowths $(Q$. cerris). Under SEM the pollen grains of all investigated representatives of this genus are characterized by a complex of two or three component types of ornamentation. Puncta on the tectum surface are obligatory. In general, three basic types of exine ornamentation, i.e. tuberculate, verrucate and rugulate, were observed (SEM).

\section{Subgenus Quercus, section Quercus}

Our analysis of exine ornamentation (SEM) of specimens of the section Quercus documents significant uniformity (i.e. the presence of complex three-component punctate-granulate-verrucate sculpture) within all three subsections (Quercus, Macrantherae, Gallifera), except for $Q$. pontica and $Q$. dshorochensis. $Q$. pontica (subsection Ponticae) shows a punctate-granulate-microtuberculate ornamentation ( $\mathrm{Pl}$. 20, fig. 1). For $Q$. dshorochensis, punctate-tuberculate ornamentation was observed (Pl. 20, fig. 5).

The data obtained indicate the appropriateness of separating $Q$. dshorochensis at species level rather than at the level of a $Q$. petraea subspecies as given by Menitsky (1984) and others (see Tab. 1).

Our data also revealed that along with their significant similarity of pollen characteristics, the main difference between the investigated specimens of $Q$. petraea and Q. iberica [accepted by Menitsky as $Q$. petraea (Matt.) Liebl. subsp. iberica (Steven) Krasiln] is the thickness of the exine layer. Thus, exine thickness for pollen of $Q$. petraea reaches 1.9-2.3 $\mu \mathrm{m}$, while for $Q$. iberica it varies within the range of 1.5-1.7 $\mu \mathrm{m}$.

\section{Subgenus Quercus, section Cerris}

Exine ornamentation in subsection Cerris is punctate-granulate-verrucate for $Q$. cerris (samples Q. cerris-1 and Q. cerris-3), placing this species closer to the majority of representatives of section Quercus; pollen of sample $Q$. cerris-1 has mainly rounded and $Q$. cerris-3 elongated verrucae.

In contrast to such species with complex verrucate ornamentation, granular elements on the surface of pollen grains of $Q$. castaneifolia are virtually absent (two-component complex ornamentation); both rounded and elongated verrucae were observed (Pl. 21, fig. 1). In his descriptions, Menitsky (1984) characterizes $Q$. castaneifolia as the least specialized and $Q$. cerris as the most specialized species within this subsection.

Species of subsection Aegilops show a quite poorly developed three-component 
Table 3. Summary of the palynomorphological characteristics of investigated species of the genus Quercus L., based on all specimens listed in Table 2 (except $Q$. cerris-2); measured from 10 pollen grains each

\begin{tabular}{l|c|c|c|c|c|c|c|c}
\hline \hline Taxon & $\begin{array}{c}\text { Pollen size } \\
{[\mu \mathrm{m}]}\end{array}$ & Type of aperture & Pore & Oncus & Geniculum & $\begin{array}{c}\text { Exine } \\
{[\mu \mathrm{m}]}\end{array}$ & $\begin{array}{c}\text { Ornamen- } \\
\text { tation }(\mathrm{LM})\end{array}$ & $\begin{array}{c}\text { Ornamentation } \\
(\mathrm{SEM})\end{array}$ \\
\hline
\end{tabular}

Subgen. QUERCUS

Section Quercus

Subsect. Ponticae

\begin{tabular}{|c|c|c|c|c|c|c|c|c|}
\hline Q. pontica & \begin{tabular}{|l|}
$17.5-22.9 \times$ \\
$19.1-23.7$
\end{tabular} & $\begin{array}{l}\text { 3-zonocolp-poroidate } \\
\text { (3-zonocolp-porate) }\end{array}$ & \begin{tabular}{|l|} 
weakly \\
expressed
\end{tabular} & - & + & $0.7-1.0$ & $\begin{array}{l}\text { regularly, } \\
\text { finely } \\
\text { verrucate }\end{array}$ & $\begin{array}{l}\text { punctate-granu- } \\
\text { late-microtuber- } \\
\text { culate }\end{array}$ \\
\hline \multicolumn{9}{|c|}{ Subsect. Quercus } \\
\hline Q. robur & \begin{tabular}{|l|}
$15.5-23.9 \times$ \\
$21.7-26.7$
\end{tabular} & $\begin{array}{l}\text { 3(rarely 4)-zonocolp- } \\
\text { poroidate or 3(rarely } \\
\text { 4)-zonocolp-porate }\end{array}$ & $\begin{array}{l}\text { weakly } \\
\text { expressed }\end{array}$ & - & + & $1.8-2.1$ & verrucate & $\begin{array}{l}\text { punctate-granu- } \\
\text { late-verrucate }\end{array}$ \\
\hline Q. petraea & $\begin{array}{l}22.5-28.0 \times \\
23.1-27.8\end{array}$ & $\begin{array}{l}\text { 3-zonocolpate, some- } \\
\text { times 3-zonocolp- } \\
\text { poroidate }\end{array}$ & \begin{tabular}{|l} 
absent or \\
weakly \\
expressed
\end{tabular} & - & + & $1.9-2.3$ & verrucate & $\begin{array}{l}\text { punctate-granu- } \\
\text { late-verrucate }\end{array}$ \\
\hline Q. iberica & $\begin{array}{l}24.5-27.8 \times \\
24.2-33.1\end{array}$ & $\begin{array}{l}\text { 3-zonocolpate or } \\
\text { 3-zonocolp-poroidate }\end{array}$ & $\begin{array}{l}\text { absent or } \\
\text { weakly } \\
\text { expressed }\end{array}$ & - & + & $1.5-1.7$ & verrucate & $\begin{array}{l}\text { punctate-granu- } \\
\text { late-verrucate }\end{array}$ \\
\hline $\begin{array}{l}\text { Q. dschoro- } \\
\text { chensis }\end{array}$ & \begin{tabular}{|l|}
$21.1-32.5 \times$ \\
$22.3-28.7$
\end{tabular} & \begin{tabular}{|l} 
3-zonocolpate, \\
3-zonocolp-poroidate \\
or 3-zonocolp-porate
\end{tabular} & \begin{tabular}{|l|} 
absent, weakly \\
expressed or \\
clearly defined
\end{tabular} & - & - & $2.3-2.6$ & verrucate & \begin{tabular}{|l|} 
punctate-tuber- \\
culate with fine \\
granules or spines
\end{tabular} \\
\hline \multicolumn{9}{|c|}{ Subsect. Macrantherae } \\
\hline $\begin{array}{l}\text { Q. macran- } \\
\text { thera }\end{array}$ & \begin{tabular}{|l|}
$25.6-34.2 \times$ \\
$28.2-38.7$
\end{tabular} & $\begin{array}{l}\text { 3-zonocolpate, } \\
\text { 3-zonocolp-poroidate }\end{array}$ & \begin{tabular}{|l|} 
absent or \\
weakly \\
expressed
\end{tabular} & - & + & $2.4-2.6$ & verrucate & $\begin{array}{l}\text { punctate-granu- } \\
\text { late-verrucate }\end{array}$ \\
\hline Q. frainetto & \begin{tabular}{|l|}
$22.3-32.2 \times$ \\
$24.8-31.9$
\end{tabular} & $\begin{array}{l}\text { 3-zonocolpate, } \\
\text { 3-zonocolp-poroidate }\end{array}$ & $\begin{array}{l}\text { absent or } \\
\text { weakly } \\
\text { expressed }\end{array}$ & - & + & $1.7-2.2$ & verrucate & $\begin{array}{l}\text { punctate-granu- } \\
\text { late-verrucate }\end{array}$ \\
\hline \multicolumn{9}{|c|}{ Subsect. Gallifera } \\
\hline Q. araxina & \begin{tabular}{|l|}
$18.5-23.5 \times$ \\
$15.8-27.0$
\end{tabular} & $\begin{array}{l}\text { 3-zonocolp-poroidate } \\
\text { (occasionally 3-zono- } \\
\text { colp-porate) }\end{array}$ & \begin{tabular}{|l} 
often weakly \\
expressed
\end{tabular} & + & + & $1.7-2.0$ & verrucate & \begin{tabular}{|l|} 
punctate-granu- \\
late-verrucate (or \\
microverrucate)
\end{tabular} \\
\hline Q. pubescens & $\begin{array}{l}19.7-27.3 \times \\
18.5-32.9\end{array}$ & $\begin{array}{l}\text { 3-zonocolpate, } \\
\text { 3-zonocolp-poroidate }\end{array}$ & $\begin{array}{l}\text { absent or } \\
\text { weakly } \\
\text { expressed }\end{array}$ & - & + & $1.4-1.6$ & verrucate & $\begin{array}{l}\text { punctate-granu- } \\
\text { late-verrucate }\end{array}$ \\
\hline Q. faginea & $\begin{array}{l}21.0-25.1 \times \\
20.1-26.3\end{array}$ & $\begin{array}{l}\text { 3-zonocolp-poroidate } \\
\text { or 3-zonocolp-porate }\end{array}$ & \begin{tabular}{|l|} 
weakly \\
expressed or \\
clearly defined, \\
usually oblong
\end{tabular} & + & + & $1.6-1.8$ & verrucate & $\begin{array}{l}\text { punctate-granu- } \\
\text { late-verrucate }\end{array}$ \\
\hline
\end{tabular}

\section{Section Cerris}

Subsect. Cerris

\begin{tabular}{l|l|l|l|c|c|c|l|l}
\hline Q. castaneifolia & $\begin{array}{l}22.0-31.3 \times \\
21.2-30.7\end{array}$ & $\begin{array}{l}\text { 3-zonocolp-poroidate } \\
\text { or 3-zonocolp-porate }\end{array}$ & $\begin{array}{l}\text { weakly } \\
\text { expressed or } \\
\text { clearly defined, } \\
\text { usually oblong }\end{array}$ & + & + & $1.6-1.8$ & granulate & $\begin{array}{l}\text { punctate-verru- } \\
\text { cate }\end{array}$ \\
\hline Q. cerris & $\begin{array}{l}22.5-26.7 \times \\
27.6-33.5\end{array}$ & $\begin{array}{l}3 \text {-zonocolp-poroidate } \\
\text { or 3-zonocolp-porate }\end{array}$ & $\begin{array}{l}\text { weakly } \\
\text { expressed or } \\
\text { clearly defined, } \\
\text { usually oblong }\end{array}$ & + & + & $1.2-1.4 \begin{array}{l}\text { spherical } \\
\text { or slightly } \\
\text { elongated, } \\
\text { densely } \\
\text { arranged } \\
\text { outgrowths }\end{array}$ & $\begin{array}{l}\text { punctate-granu- } \\
\text { late-verrucate }\end{array}$ \\
\hline
\end{tabular}

Subsect. Aegilops

\begin{tabular}{l|l|l|l|c|c|c|l|l}
\hline Q. brantii & $\begin{array}{l}18.6-32.2 \times \\
14.3-26.8\end{array}$ & $\begin{array}{l}\text { 3-zonocolp-poroidate } \\
\text { (sometimes 3-zono- } \\
\text { colp-porate) }\end{array}$ & $\begin{array}{l}\text { weakly } \\
\text { expressed or } \\
\text { clearly defined, } \\
\text { usually elon- } \\
\text { gated }\end{array}$ & + & + & $1.2-1.3$ & $\begin{array}{l}\text { finely } \\
\text { verrucate }\end{array}$ & $\begin{array}{l}\text { punctate-granu- } \\
\text { late-verrucate }\end{array}$ \\
\hline Q. persica & $\begin{array}{l}18.2-27.8 \times \\
17.5-29.4\end{array}$ & $\begin{array}{l}\text { 3-zonocolpate or } \\
\text { 3-zonocolp-poroidate }\end{array}$ & $\begin{array}{l}\text { absent or } \\
\text { weakly } \\
\text { expressed }\end{array}$ & - & - & $1.3-1.4$ & $\begin{array}{l}\text { finely } \\
\text { verrucate }\end{array}$ & $\begin{array}{l}\text { punctate-granu- } \\
\text { late-verrucate }\end{array}$ \\
\hline Q. aegilops & $\begin{array}{l}23.6-32.8 \times 28.2 \\
\text { 3-zonocolpate, } \\
\text { 3-zonocolp-poroidate } \\
\text { (rarely 3-zonocolp- } \\
\text { porate) }\end{array}$ & $\begin{array}{l}\text { absent, weakly } \\
\text { expressed, } \\
\text { rarely clearly } \\
\text { defined, usu- } \\
\text { ally elongated }\end{array}$ & + & + & $1.3-1.4$ & verrucate & $\begin{array}{l}\text { punctate-granu- } \\
\text { late-microverru- } \\
\text { cate }\end{array}$ \\
\hline
\end{tabular}


Table 3. Continued

\begin{tabular}{|c|c|c|c|c|c|c|c|c|}
\hline Taxon & $\begin{array}{c}\text { Pollen size } \\
{[\mu \mathrm{m}]}\end{array}$ & Type of aperture & Pore & Oncus & Geniculum & $\begin{array}{c}\text { Exine } \\
{[\mu \mathrm{m}]}\end{array}$ & \begin{tabular}{|c|} 
Ornamen- \\
tation (LM)
\end{tabular} & $\begin{array}{l}\text { Ornamentation } \\
\text { (SEM) }\end{array}$ \\
\hline \multicolumn{9}{|c|}{ Subgen. HETEROBALANUS } \\
\hline \multicolumn{9}{|c|}{ Section Heterobalanus } \\
\hline \multicolumn{9}{|c|}{ Subsect. Heterobalanus } \\
\hline Q. alnifolia & \begin{tabular}{|l|}
$15.7-20.3 \times$ \\
$15.2-23.5$
\end{tabular} & $\begin{array}{l}\text { 3-zonocolp-poroidate } \\
\text { (rarely 3-zonocolp- } \\
\text { porate) }\end{array}$ & $\begin{array}{l}\text { often weakly } \\
\text { expressed }\end{array}$ & + & + & $1.2-1.4$ & \begin{tabular}{|l} 
finely \\
verrucate
\end{tabular} & $\begin{array}{l}\text { from punctate- } \\
\text { microverrucate to } \\
\text { punctate-verru- } \\
\text { cate- tuberculate, } \\
\text { sometimes punc- } \\
\text { tate-verrucate- } \\
\text { rugulate }\end{array}$ \\
\hline \multicolumn{9}{|c|}{ Subsect. Suber } \\
\hline Q. suber & \begin{tabular}{|l|}
$16.3-27.2 \times$ \\
$17.4-32.5$
\end{tabular} & $\begin{array}{l}\text { 3-zonocolp-poroidate } \\
\text { (rarely 3-zonocolp- } \\
\text { porate) }\end{array}$ & $\begin{array}{l}\text { often weakly } \\
\text { expressed }\end{array}$ & + & + & $1.5-1.7$ & \begin{tabular}{|l} 
finely \\
verrucate
\end{tabular} & $\begin{array}{l}\text { punctate-granu- } \\
\text { late-verrucate }\end{array}$ \\
\hline \multicolumn{9}{|l|}{$\begin{array}{l}\text { Section Ilex } \\
\text { Subsect. Ilex }\end{array}$} \\
\hline Q. ilex & \begin{tabular}{|l|}
$18.6-29.6 \times$ \\
$20.1-32.0$
\end{tabular} & $\begin{array}{l}\text { 3-zonocolpate, } \\
\text { 3-zonocolp-poroidate }\end{array}$ & \begin{tabular}{|l|} 
absent or \\
weakly \\
expressed
\end{tabular} & - & + & $1.2-1.5$ & 'spinulose' & $\begin{array}{l}\text { punctate-microru- } \\
\text { gulate }\end{array}$ \\
\hline \multicolumn{9}{|c|}{ Subsect. Cocciferae } \\
\hline Q. coccifera & \begin{tabular}{|l|}
$17.4-23.1 \times$ \\
$15.5-23.6$
\end{tabular} & $\begin{array}{l}\text { 3-zonocolp-poroidate } \\
\text { (rarely 3-zonocolp- } \\
\text { porate) }\end{array}$ & $\begin{array}{l}\text { often weakly } \\
\text { expressed }\end{array}$ & + & + & $1.2-1.4$ & \begin{tabular}{|l|} 
finely \\
verrucate
\end{tabular} & $\begin{array}{l}\text { punctate-microru- } \\
\text { gulate }\end{array}$ \\
\hline
\end{tabular}

punctate-granulate-verrucate type of sculpture with elongated cone-shaped (sometimes rounded), usually irregularly arranged (micro) verrucae of different sizes, sometimes merging laterally.

Along with their significant similarity of pollen characteristics, the main difference between the investigated specimens of $Q$. brantii and $Q$. persica (generally accepted as synonym of Q. brantii; see Tab. 1) is that the former is characterized by more highly specialized complex 3-zonocolp-poroidate, sometimes 3-zonocolp-porate apertures, while in the pollen of $Q$. persica the pores are either weakly expressed (3-zonocolp-poroidate) or absent (3-zonocolpate).

\section{Subgenus Heterobalanus, section Heterobalanus}

In subsection Heterobalanus the exine ornamentation of pollen grains of $Q$. alnifolia varies from punctate-microverrucate to punctate-verrucate-tuberculate, sometimes punctate-verrucate-rugulate (Pl. 21, figs 7, 8).

In subsection Suber the pollen of $Q$. suber shows a punctate-granulate-verrucate type of exine ornamentation, typical for the vast majority of species of subgenus Quercus (Pl. 21, fig. 9). According to Menitsky (1984), this species may be an ancient intersectional hybrid between some species from section
Heterobalanus and species close to $Q$. aegilops from subgenus Quercus. This probably explains the observed similarity of exine ornamentation of pollen of $Q$. suber with that of representatives of subgenus Quercus.

\section{Subgenus Heterobalanus, section Ilex}

Representatives of both subsections of section Ilex have punctate-microrugulate exine ornamentation. Rugae sometimes are fused laterally, forming spine-like excrescences. In contrast to $Q$. ilex (subsection Ilex), rugae on the surface of pollen of $Q$. coccifera (subsection Cocciferae) are sinuous and often branched, mainly located in different planes and intertwined with each other (Pl. 21, fig. 11).

In general, our data highlight the palynomorphological heterogeneity of subgenus Heterobalanus.

\section{POLLEN MORPHOTYPES}

Based on the basic types of exine ornamentation as described above, six morphological types of pollen can be distinguished.

\section{Tuberculate types}

Type $Q$. dshorochensis: ornamentation punctate-tuberculate; species: Q. dshorochensis (subgenus Quercus). 

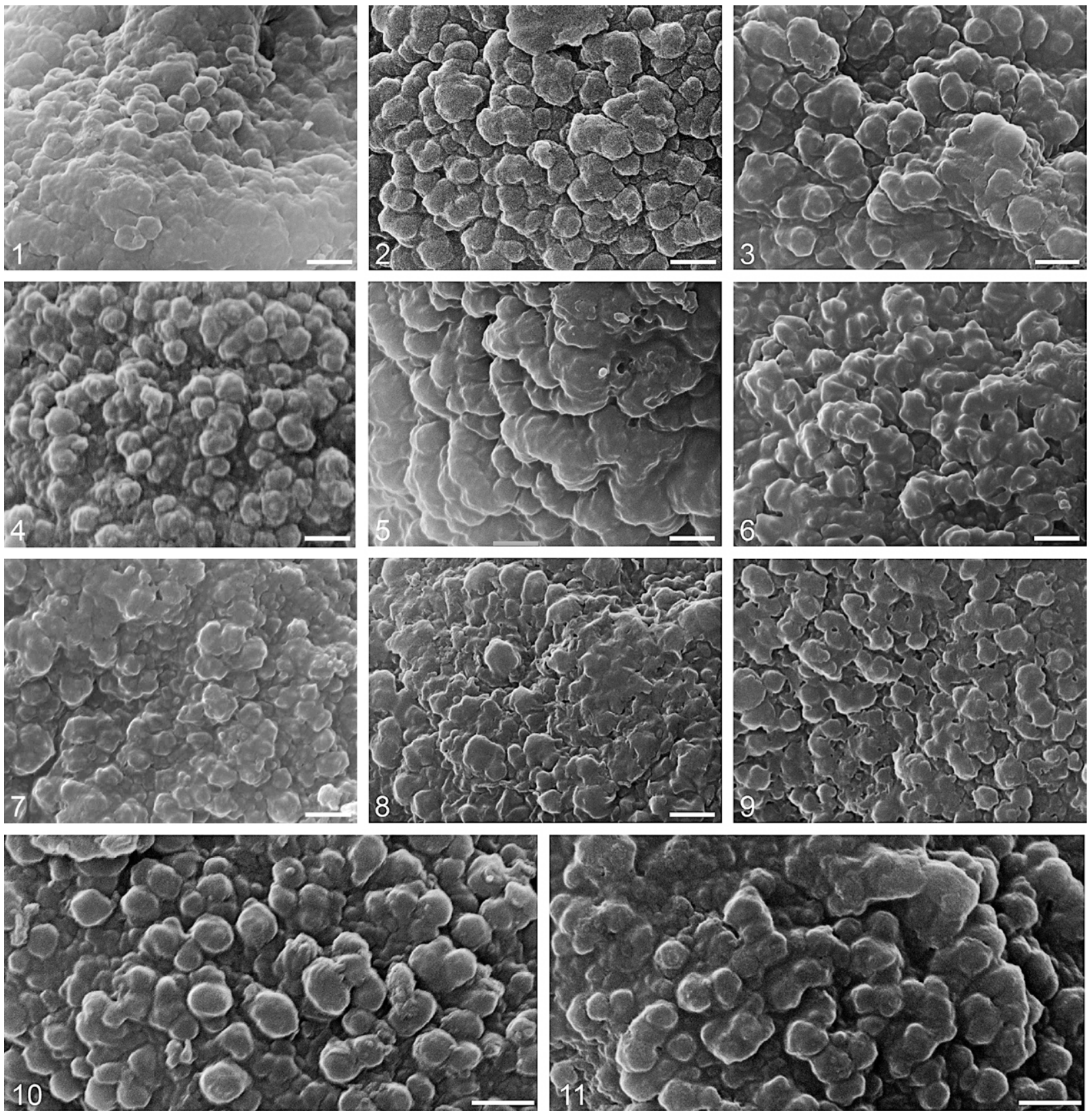

Plate 20. SEM micrographs. Exine ornamentation (mesocolpium) in the genus Quercus. Subgen. Quercus, sect. Quercus, subsect. Ponticae: 1. Q. pontica; subsect. Quercus: 2. Q. robur, 3. Q. petraea, 4. Q. iberica, 5. Q. dschorochensis; subsect. Macrantherae: 6. Q. macranthera, 7. Q. frainetto; subsect. Gallifera: 8. Q. araxina, 9. Q. pubescens-1, 10, 11. Q. faginea (scale bar $1 \mu \mathrm{m})$

Type $Q$. pontica: ornamentation punctate-granulate-microtuberculate; species: $Q$. pontica (subgenus Quercus).

\section{Verrucate types}

Type Q. castaneifolia: ornamentation punctate-microverrucate, verrucae rounded or elongated, densely arranged, usually in small groups, fused laterally; species: $Q$. castaneifolia (subgenus Quercus).

Type $Q$. robur: ornamentation punctate-granulate-verrucate.
Subtype-1 Q. aegilops: granula arranged on the tectum between verrucae; verrucae (or microverrucae) irregularly arranged, varying in size, rounded or conically elongate, sometimes fused laterally; species: $Q$ aegilops, $Q$. brantii, $Q$. persica (subgenus Quercus).

Subtype-2 Q. robur: granula arranged on the tectum between verrucae, often on the verrucae also; verrucae usually rounded, varying in size, often located in small groups, fused laterally; species: Q. robur, $Q$. petraea, $Q$. iberica, $Q$. macranthera, $Q$. frainetto, $Q$. araxina, $Q$. pubescens, 

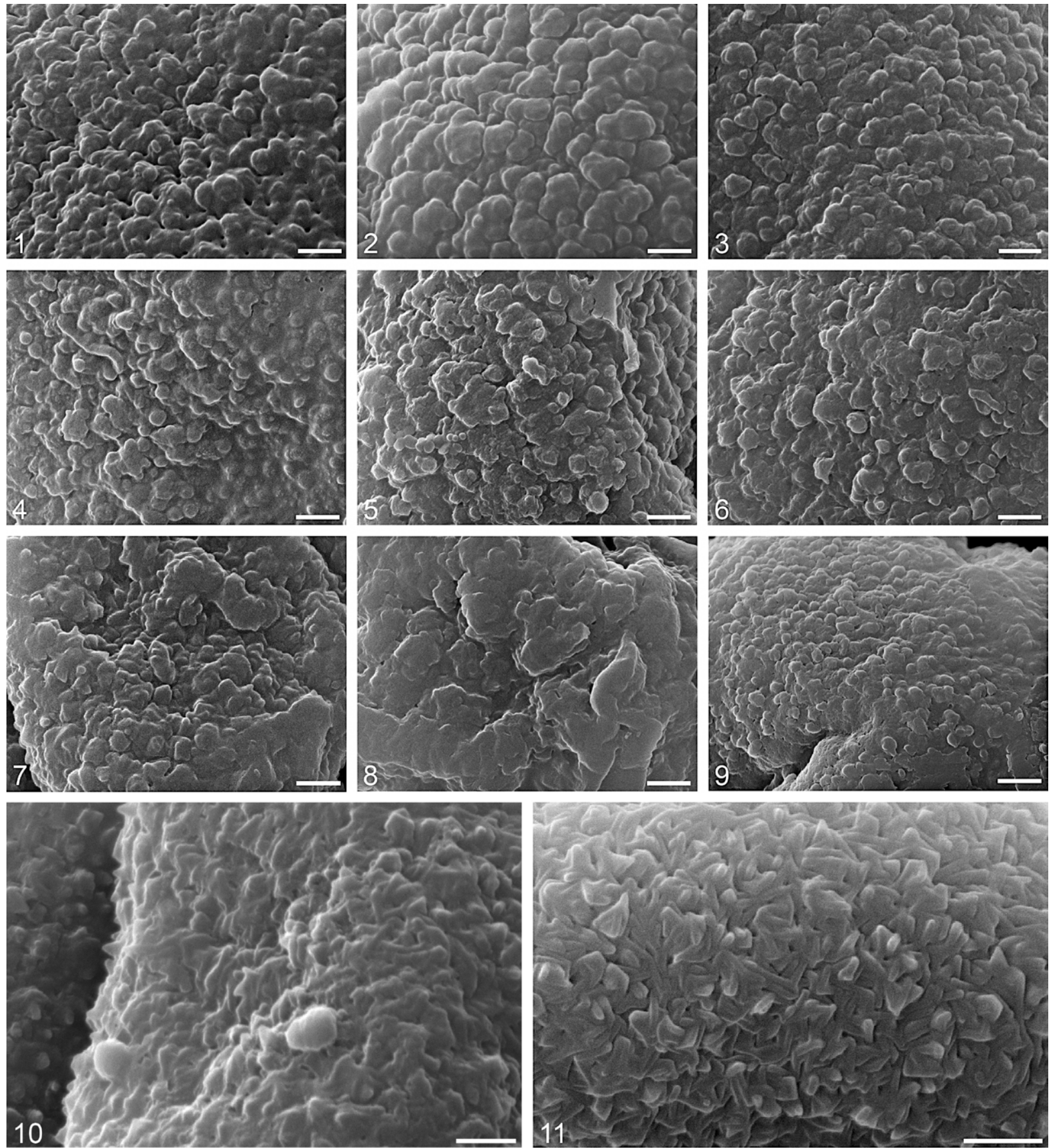

Plate 21. SEM micrographs. Exine ornamentation (mesocolpium) in the genus Quercus. Subgen. Quercus, sect. Cerris, subsect. Cerris: 1. Q. castaneifolia, 2. Q. cerris-1, 3. Q. cerris-3; subsect. Aegilops: 4. Q. brantii, 5. Q. persica, 6. Q. aegilops; Subgen. Heterobalanus, sect. Heterobalanus, subsect. Heterobalanus: 7, 8. Q. alnifolia; subsect. Suber: 9. Q. suber; sect. Ilex, subsect. Ilex: 10. Q. ilex; subsect. Cocciferae: 11. Q. coccifera (scale bar $1 \mu \mathrm{m}$ )

Q. faginea, Q. cerris (samples 1, 3) (subgenus Quercus), Q. suber (subgenus Heterobalanus).

\section{Rugulate type}

Type $Q$. ilex: ornamentation punctate-microrugulate; rugulae irregularly arranged, few rugulae usually fuse laterally, forming spinelike excrescences; species: $Q$. ilex, $Q$. coccifera (subgenus Heterobalanus).

\section{Variable type}

Type $Q$. alnifolia: ornamentation varies from punctate-microverrucate to punctate-verrucate-tuberculate, sometimes punctate-verrucate-rugulate; verrucae solitary and of variable size, rounded or elongated; species: $Q$. alnifolia (subgenus Heterobalanus). 


\section{DISCUSSION}

In the present study we clarified a number of the most important diagnostic features of the pollen of some species of the genus Quercus. Our investigations confirmed that the main aperture type of pollen within the genus is 3-zonocolp-porate (less often 3-zonocolpate), but not 3-zonocolp-orate as shown in some literature sources (e.g. Naryshkina, 2013; Tekleva and Polevova, 2014); the presence of onci under the pore areas is firm evidence of this. The morphological descriptions and the short terminological glossary explain the detailed characteristics and distinctive features of the main aperture types, based on their location in different layers of the exine, as well as their function.

In general, three basic types of exine ornamentation are observed: tuberculate, verrucate and rugulate. For the majority (12 out of 15) of species of subgenus Quercus (except for $Q$. pontica, $Q$. dshorochensis and $Q$. castaneifolia), we found verrucate, in particular complex three-component punctate-granulateverrucate ornamentation (SEM).

In contrast to subgenus Quercus, subgenus Heterobalanus is heterogeneous with respect to its pollen morphology. Among four species studied, $Q$. suber shows a punctate-granulateverrucate type of exine ornamentation, which places this species closer to subgenus Quercus. Species $Q$. ilex and $Q$. coccifera reveal punctate-microrugulate exine ornamentation, whereas the exine ornamentation of the pollen of $Q$. alnifolia varies from punctate-microverrucate to punctate-verrucate-tuberculate, sometimes punctate-verrucate-rugulate.

Based on these data we postulate the existence of a common initial type of exine ornamentation from which the types described above could have developed in two directions (Fig. 1).

The first direction (A) is represented by three possible levels of evolutionary development of exine ornamentation. The first level combines species from morphotypes $Q$. pontica, Q. dshorochensis and Q. alnifolia, which are characterized by the simplest (mainly tuberculate) type of sculpture. The allocation of the species $Q$. pontica as a separate morphotype within the subgenus Quercus is fully in line with data from molecular phylogenetic studies (Denk and Grimm, 2010: 357): '...individuals of the narrow endemic species $Q$. pontica formed a distinct group'. To some extent this also applies to the species $Q$. alnifolia (subgenus Heterobalanus), with a type of exine ornamentation which is clearly distinct from that of morphotype $Q$. ilex (in the same subgenus), and points to a completely different direction in the evolution of exine ornamentation. As Denk and Grimm (2010: 357) stated, 'Within the ilicoid oaks, two distinct groups were recognized: one consisting of $Q$. alnifolia and $Q$. aucheri intermixing with $Q$. coccifera, and one including only $Q$. ilex'.

On the second level of direction A, species with punctate-microverrucate ornamentation are considered, where sculptural elements are not always clearly expressed (morphotype $Q$. castaneifolia). On the third level we place morphotype $Q$. robur (comprising most of the investigated species from subgenus Quercus, as well as Q. suber from subgenus Heterobalanus) with its predominantly highly ornamented and regularly spaced three types of sculptural elements (punctae, verrucae, granulae) as the most advanced one.

For Jarvis et al. (1992) the main differences between pollen of deciduous and evergreen species of Quercus is expressed in the presence of pores and well-developed genicula in evergreen species and their absence in deciduous ones. Our data, however, do not confirm this point of view, as geniculum (and pore) occur in both subgenera of the genus Quercus, deciduous species of the subgenus Quercus, as well as evergreen species of the subgenus Heterobalanus. In this context it is interesting to note that Schwarz (1936a, 1937) suggested that the primitive leaf of Quercus was neither deciduous nor evergreen, and that the change in life expectancy (of the leaf) depends on climate and growth rhythm. Thus, obligatory deciduousness and evergreenness are secondary features according to this author. Menitsky (1984) also noted that some members of the subgenus Heterobalanus initially evolved towards a sclerophyll leaf-type, developing back to deciduousness and meso- and macrophyll leaves when spreading to higher latitudes. The North American deciduous subgenus Erythrobalanus seems to follow the same evolutionary path according to Menitsky (1984).

The fact that both species of the section Heterobalanus are closer to representatives of subgenus Quercus than to section Ilex confirms the 


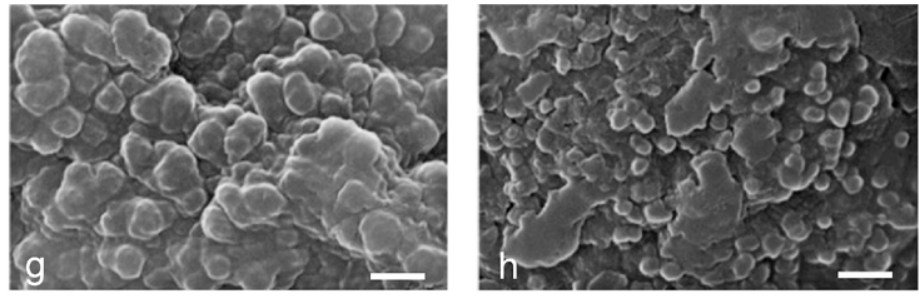

Type Q. robur
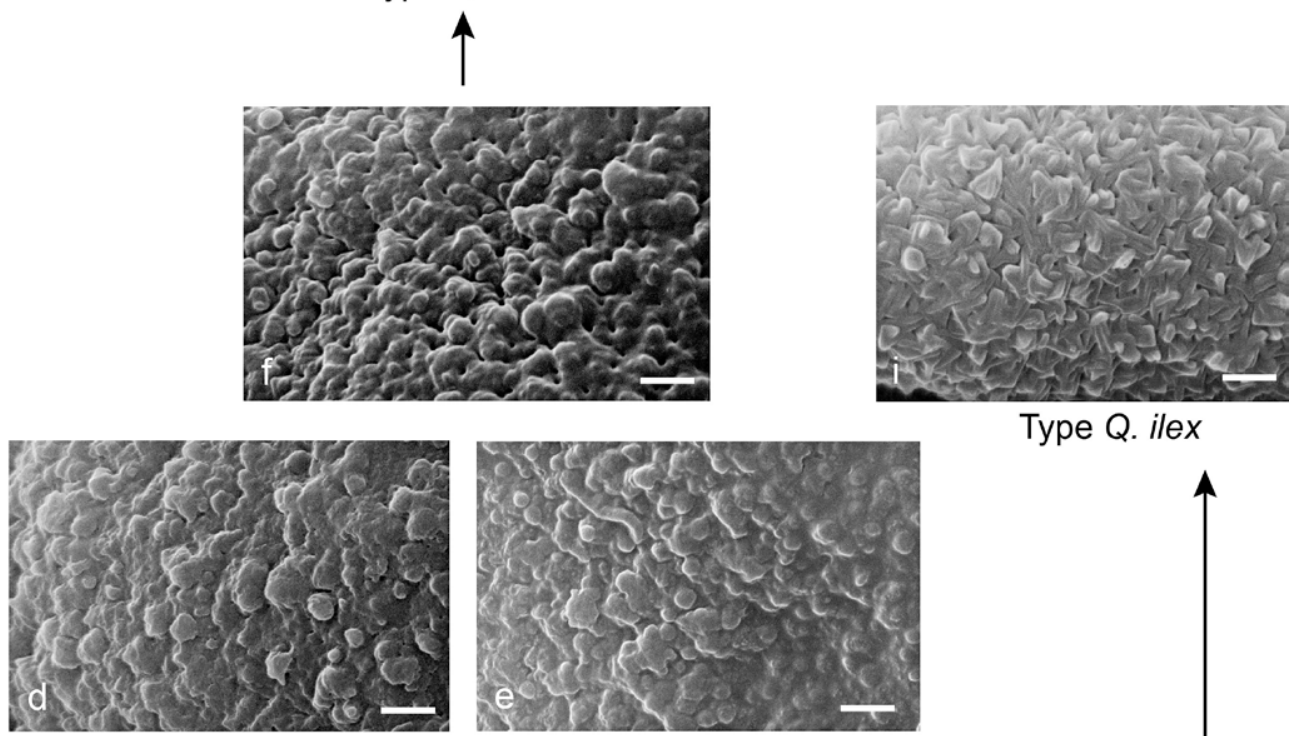

Type Q. ilex

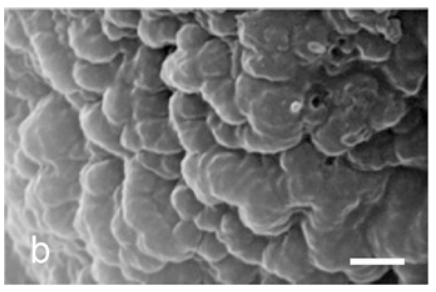

Type Q. dshorochensis

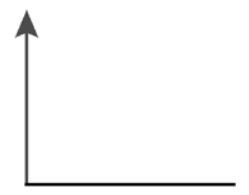

Type Q. castaneifolia
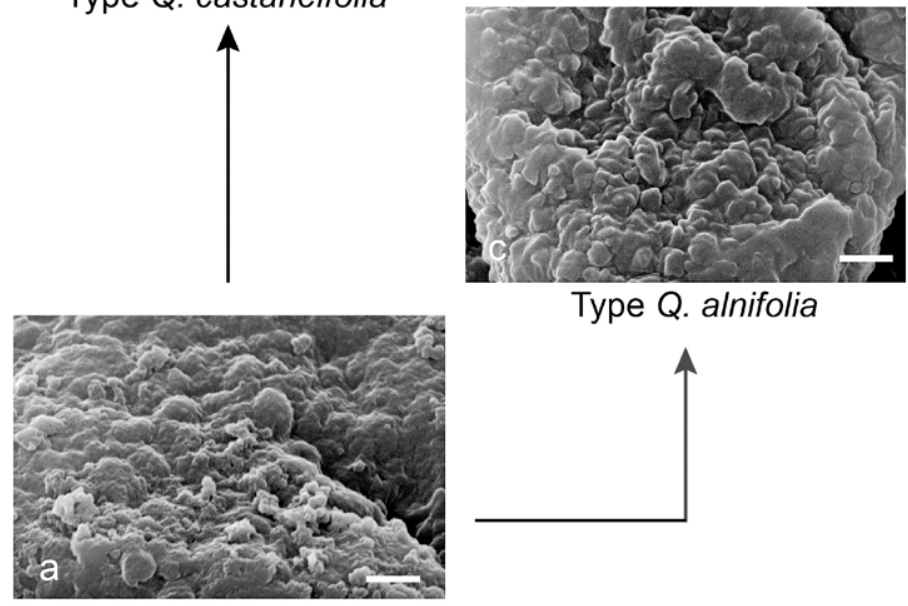

Type Q. alnifolia

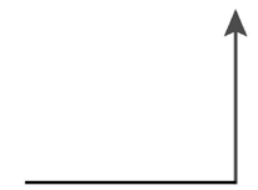

Type Q. pontica

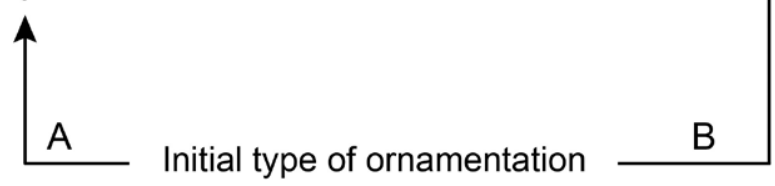

Fig. 1. Scheme of the two main directions of evolutionary development of exine ornamentation in the genus Quercus (subgenera Quercus and Heterobalanus, sensu Menitsky 1984), supposed to have evolved from a common initial type. The first direction (A) includes all species studied from subgenus Quercus as well two of four investigated species of subgenus Heterobalanus. The second direction (B), represented by only one morphotype, covers two species from subgenus Heterobalanus $(Q$. ilex, Q. coccifera). a. Q. pontica; b. Q. dshorochensis; c. Q. alnifolia; d. Q. aegilops; e. Q. brantii; f. Q. castaneifolia; g. Q. petraea; h. $Q$. suber (islets with secondary accumulated sporopollenin are visible); i. $Q$. ilex (scale bar $1 \mu \mathrm{m}$ )

opinion of Schottky (1912) that both sections of subgenus Heterobalanus are affiliated to different quite specialized genetic series.

Direction B is represented by morphotype Q. ilex (Fig. 1). It developed separately and probably is rather a specialized group of species having a common ancestor with direction A but not being initial to it. This model opposes Denk and Grimm (2009), who placed Q. ilex at the base of the phylogenetic tree of the family 
Fagaceae due to the presence of a similar type of ornamentation in pollen of the genus Fagus. However, later Denk and Tekleva (2014) considered the foot layer of Fagus pollen as derived. Furthermore, data of Denk and Grimm (2010: fig. 6) and Denk et al. (2017: fig. 2.2) are in line with our model of some initial ancestral Quercus species (or group of species), from which evolution could occur in two different directions (A and B in Fig. 1). For further clarification regarding species of the Cerris group and the question of their proximity to subgenus Quercus (sensu Menitsky, 1984) or to Ilicoid oaks (sensu Denk and Grimm, 2010; Hipp et al., 2015) more palynomorphological investigations concentrating on the respective species are required.

Our study confirms once again the similarity of the type of exine ornamentation of groups of closely related species in the genus Quercus. In particular, we documented considerable consistency of the type of exine ornamentation (punctate-granulate-verrucate) for the majority of investigated species within subgenus Quercus, as well as for $Q$. suber (subgenus Heterobalanus). The similarity of exine ornamentation for a number of species within the genus Quercus is also confirmed by Wrońska-Pilarek et al. (2016) in a study of the pollen morphology of $Q$. robur, $Q$. petraea and Q. pubescens. The authors state that 'On the basis of exine ornamentation, it was possible to identify only $Q$. pubescens, while the remaining species and hybrids did not differ significantly with respect to this feature', adding that 'Pollen morphological features allow to distinguish a part of the studied Quercus taxa' (Wrońska-Pilarek et al., 2016: 1). Besides other possible factors, such similarities of exine surface patterns can be explained by hybridization, as hybridization is quite likely and also has been inferred in genetic studies. According to Kremer et al. (2012), '...oaks are also model species to investigate genomic delineation of species, as hybridization frequently occurs between species of the same taxonomic sections of Quercus'. As Wodehouse (1935) pointed out, pollen of some Quercus species exhibits many irregularities, generally denoting the hybridity of their origin.

In addition to the basic sculptural elements, islets with secondary accumulated sporopollenin which almost completely hide the exine pattern are regularly observed (Fig. 1h). Such sporopollenin excrescences with varying shape and dimensions were noted earlier by Meyer (1980), according to whom these islets are a result of asynchronous supply of sporopollenin to the surface of the pollen grains, and their presence should be regarded as a primitive feature.

Discussing the possible pathways of evolution of ornamentation types, another peculiarity of Quercus pollen has to be taken into account. Rowley and Gabaraeva (2004) used electron microscopy to study different stages of pollen ontogeny of $Q$. robur in conjunction with a study of features of the inner layer of anther cells, namely the tapetum, involved in delivery of substances to developing microspores and pollen grains. They found that the tapetum remains active and is bordered by Ubish bodies, or orbicules. They also revealed that, after acetolysis followed by exposure to potassium permanganate, all of the exine that is exposed, including the verrucae, is composed of rod-shaped tufts. The reason for this phenomenon, according to them, could be that the verrucate sculpture is secondarily derived and that the initial structure is a rod-shaped tuft structure formed by primary deposited sporopollenin. If the resistant nature of the primarily accumulated sporopollenin has to do with its accumulation on plasma membrane glycocalyx macromolecules (i.e. sporopollenin accumulating particles, SAPs), then secondarily accumulated sporopollenin is not bound to SAPs and is more vulnerable to oxidation (Rowley and Gabaraeva, 2004).

Therefore, in our opinion, the surface of pollen of representatives of almost all infrageneric groups of the genus Quercus is generated by different combinations of regularly or irregularly arranged, round or elongated excrescences of various sizes, which occur individually or in groups and which certainly are coated with a layer of secondarily accumulated sporopollenin. This layer varies in thickness, and is least developed on the pollen of the $Q$. ilex group.

\section{CONCLUSION}

Our study provides a detailed analysis of the morphology of pollen of 19 recent species of the genus Quercus from Armenia and adjacent regions including the Caucasus and Transcaucasia, the Mediterranean region (especially Turkey), as well as Iran, Iraq and Afghanistan. The vast majority of the investigated species belong to subgenus Quercus (exclusively deciduous trees and shrubs from 
warm-temperate to cold-temperate regions of Eurasia and North America), while four species belong to subgenus Heterobalanus (sclerophyllous evergreen trees and shrubs restricted mainly to warm-temperate regions). In combination with published information, our comparative palynomorphological analysis of those species allowed an assessment at different levels of taxonomic rank.

In our opinion, the 'verrucate' ('granular', 'tuberculate') type of ornamentation described for many representatives of subgenus Quercus, forming at later stages of pollen ontogeny by secondary accumulated sporopollenin, and being more vulnerable to oxidation (Rowley and Gabaraeva, 2004), can hardly be considered a true sculpture. It can be assumed that in the case of pollen grains of most species of subgenus Quercus, it probably is not true ornamentation but rather a not yet fully formed and not finally genetically fixed pattern (i.e. pre-ornamentation) of the surface, common to many closely related species. This pattern is generally similar for a number of species and varies within individual taxa and specimens in shape, size, density, distribution of individual sculptural elements, etc. Therefore, in most cases this pattern cannot serve as a principal interspecific diagnostic feature.

Furthermore, the presence of widespread interspecific and introgressive hybridization indicates that the boundaries between species have not yet been completely fixed. This also has an effect on pollen features, which are very similar in a number of species but vary in individual samples even within the same species, significantly reducing the importance of pollen morphological characters in solving a number of problems in systematics. Hybridization, or the introgressive nature of individuals, can play an important role in evolution, for example via the formation of new species or increasing genetic variation within species, but may also cause taxonomic confusion, especially in the genera Fagus and Quercus (Fortini et al., 2015). We suggest that the different directions of evolutionary processes within these genera could well result in a number of distinctive morphological features that make it possible to clearly outline their taxonomic boundaries.

For the genus Fagus, evolving much earlier than the remaining lineages within the Fagaceae (Grimson et al., 2016) and currently represented by only 10-12 species limited to temperate, subtropical and partially tropical zones of Europe, Asia and North America, the pace of evolutionary development seems to have significantly slowed down, oriented towards further development and improvement of existing features. In the case of pollen, for example, these are the 3-colp-orate apertures with well-defined ora and vermiculate (rugulate) exine ornamentation.

For the genus Quercus the presence of 3-zonocolpate or 3-zonocolp-poroidate apertures, the morphological uniformity of the pollen surface pattern, noted mainly for species of subgenus Quercus, the presence of islets of secondary sporopollenin on the surface of pollen grains as well as orbicules in anthers, do not indicate general primitiveness of representatives of this genus but most likely denote relatively high speciation activity within this group. The data presented only confirms Menitsky's (1984) opinion that subgenus Quercus is the youngest and evolutionarily more advanced subgenus of the genus. As a result, Quercus species show wider and significantly more variable habitat preferences, as well as a higher number of species, than in Fagus. In this matter we agree with Tekleva (2012) that this genus is 'at the height of its development'. This, in our opinion, explains the existing instability and variability of various features, including pollen morphological traits, which are usually considered the main diagnostic characters for determination of taxa at generic and species levels.

\section{ACKNOWLEDGEMENTS}

We thank Dr. Stefan Dressler (Senckenberg Research Institute, Frankfurt, Germany), Prof. Dr. Johanna Kovar-Eder (Nature and History Museum, Stuttgart, Germany) and Dr. Ivan Gabrielyan (Institute of Botany, National Academy of Sciences, Yerevan, Armenia) for their help in collecting pollen material, Claudia Groth (Senckenberg Research Institute, Frankfurt, Germany) for laboratory and technical assistance and for part of the light microscopy, Claudia Franz (Senckenberg Research Institute, Frankfurt, Germany) for technical assistance with SEM photography, and cand.-geol. Leonie Horst (Senckenberg Research Institute, Frankfurt, Germany) for preparation of plates. We are grateful to the anonymous referees for their suggestions, which helped to substantially improve the original manuscript. This study was conducted with the financial support of DAAD (German Academic Exchange Service), the Heidelberg Academy of Sciences, and the Volkswagen Foundation (grant no. 85 820). It is a contribution to NECLIME (www.neclime.de) and ROCEEH (www.roceeh.net). 


\section{REFERENCES}

Avetisyan, E.M., 1950. Uproshchenny atsetolizny metod obrabotki pil'tsi. Botanicheskii Zhurnal 35(4), 385-387 (in Russian).

Avetisyan, E.M., Hayrapetyan, A.M., 2002. K terminologii slozhnikh apertur (summary: On the terminology of compound apertures of pollen grains). Flora, rastitel'nost' i rastitel'nie resursy Armenii 14, 64-67 (in Russian).

Avetisyan, E.M., Manukyan, L.K., 1962. Opisanie pil'tsi semeystva Fagaceae. Flora Armenii, 4. Akademiya Nauk ArmSSR, Yerevan (in Russian).

Barrón, E., Averyanova, A., Kvaček, Z., Momohara, A., Pigg, K.B., Popova, S., Postigo-Mijarra, J.M., Tiffney, B.H., Utescher, T., Zhou, Z.K., 2017. The fossil history of Quercus. In: Gil-Pelegrín, E., PegueroPina, J.J., Sancho-Knapik, D. (eds), Oaks physiological ecology. Exploring the functional diversity of genus Quercus L. Tree physiology, 7. Springer, Heidelberg, New York, pp. 39-105.

Blackmore, S., Barnes, S.H., 1986. Harmomegatic mechanisms in pollen grains. In: Blackmore, S., Ferguson, I.K. (eds), Pollen and spores: form and function. Linnean Society Symposium Series, 12. Linnean Society, London, pp. 137-150.

Blanco, M.A.F., Barrera, R.M.V., Gonzalez, D.F., Merino, A.P., 1996. Estudio polínico de Quercus robur $\mathrm{L}$. en el noroeste de la península Ibérica. Botánica Macaronésica 23, 25-33.

Cao, M., Zhou, Z.K., 2002. Pollen morphology and its systematic significance of the Quercus from China. Guihaia 22, 14-18.

Colombo, P.M., Lorenzoni, F.C., Grigoletto, F., 1983. Pollen grain morphology supports the taxonomical discrimination of Mediterraneae oaks (Quercus, Fagaceae). Plant Systematics and Evolution 141, 273-284.

Czerepanov, S.K., 1995. Vascular plants of Russia and adjacent states (the former USSR). Cambridge University Press, New York, pp. 1-516.

Denk, T., Grimm, G.W., 2009. Significance of pollen characteristics for infrageneric classification and phylogeny in Quercus (Fagaceae). International Journal of Plant Sciences 170(7), 926-940.

Denk, T., Grimm, G.W., 2010. The oaks of western Eurasia: traditional classifications and evidence from two nuclear markers. Taxon 59(2), 351-366.

Denk, T., Tekleva, M.V., 2014. Pollen morphology and ultrastructure of Quercus with focus on Group Ilex (= Quercus subgenus Heterobalanus (Oerst.) Menitsky): implications for oak systematics and evolution. Grana 53(4), 255-282.

Denk, T., Grímsson, F., Zetter, R., 2012. Fagaceae from the early Oligocene of Central Europe: persisting new world and emerging old world biogeographic links. Review of Palaeobotany and Palynology $169,7-20$.

Denk, T., Grimm, G.W., Manos, P.S., Deng, M., Hipp, A.L., 2017. An updated infrageneric classification of the oaks: review of previous taxonomic schemes and synthesis of evolutionary patterns. In: GilPelegrín, E., Peguero-Pina, J.J., Sancho-Knapik, D. (eds), Oaks Physiological Ecology. Exploring the Functional Diversity of Genus Quercus L., Tree Physiology, 7. Springer, Heidelberg, New York, pp. 13-38.

Docturoski, V.S., Kudriaschow, V.V., 1923. Pil'tsa v torfe. Izvestiya Nauchno-experimental'nogo torfyanogo instituta (Moskwa) 5, 33-44 (in Russian).

Dupont, P., Dupont, S., 1972. Etude de pollens de chênes (genre Quercus L.) en microscopie électronique à balayage. Comptes rendus de l'Académie des Sciences Paris 274(17), 2503-2506.

Erdtman, G., 1923. Beitrag zur Kenntnis der Mikrofossilen in Torf und Sedimenten. Arkiv för Botanik 18(14), 1-9.

Erdtman, G., 1943. An introduction to pollen analysis. Chronica Botanica Company, Waltham.

Erdtman, G., 1952. Pollen morphology and plant taxonomy. Angiosperms. Almqvist et Wiksell, Stockholm.

Erdtman, G., Berglund, B., Praglowski, J., 1961. An introduction to a Scandinavian pollen flora. Almqvist et Wiksell, Stockholm.

Fortini, P., Antonecchia, G., Di Marzio, P., Maiuro, L., Viscosi, V., 2015. Role of micromorphological leaf traits and molecular data in taxonomy of three sympatric white oak species and their hybrids (Quercus L.). Plant Biosystems 149, 546-558.

Greenfield, E.K., 1962. Proiskhozhdenie antofilii $\mathrm{u}$ nasekomikh. Leningradski Gosudarsvenni Universitet, Leningrad (in Russian).

Grímsson, F., Zetter, R., Grimm, G.W., Krarup Pedersen, G., Pedersen, A.K., Denk, T., 2015. Fagaceae pollen from the early Cenozoic of West Greenland: revisiting Engler's and Chaney's Arcto-Tertiary hypotheses. Plant Systematics and Evolution 301, 809-832.

Grímsson, F., Grimm, G.W., Zetter, R., Denk, T., 2016. Cretaceous and paleogene Fagaceae from North America and Greenland: evidence for a Late Cretaceous split between Fagus and the remaining Fagaceae. Acta Palaeobotanica 56, 247-305.

Grossheim, A.A., 1949. Opredelitel' rasteni Kavkaza. Sovetskaja Nauka, Moskva (in Russian).

Hayrapetyan, A., 2013. Palynomorphological investigation of the genus Quercus L. In: Abstracts of the conference «The Role of the Southern Caucasus on Early Human Evolution and Expansion - Refuge, Hub or Source Area?». Tbilisi, Georgia, 73-74. http://www.roceeh.net/fileadmin/download/conferences/program_abstract_Tbilisi.pdf

Heslop-Harrison, J., 1979. An interpretation of the hydrodynamics of pollen. American Journal of Botany 66, 737-743.

Hesse, M., Halbritter, H., Zetter, R., Weber, M., Buchner, R., Frosch-Radivo, A., Ulrich, S., 2009. Pollen terminology. An illustrated handbook. Springer, Wien. 
Hill, R.S., Jordan, G.J., 1993. The evolutionary history of Nothofagus (Nothofagaceae). Australian Systematic Botany 6, 111-126.

Hill, R.S., Read, J., 1991. A revised infrageneric classification of Nothofagus (Fagaceae). Botanical Journal of the Linnean Society 105, 37-72.

Hipp, A.L., Manos, P., Mcvay, J.D., Cavender-Bare Rodriguez, A., Romero-Severson, J., Hahn, M., Budaitis, B., Deng, M., Grimm, G.W., Fitzek, E.C., Jennings, T.L., Avishai, M., Simeone, M.C., 2015. A phylogeny of the world's oaks. Botany 2015. Edmonton, Kanada, 25-29 July 2015, abstract ID 1305. http://2015.botanyconference.org/engine/ search/index.php?func $=$ detail\&aid $=1305$

Hubert, F., Grimm, G.W., Jousselin, E., Berry, V., Franc, A., Kremer, A., 2014. Multiple nuclear genes stabilize the phylogenetic backbone of the genus Quercus. Systematics and Biodiversity 12, 405-423.

Hyde, H.A., 1955. Oncus, a new term in pollen morphology. New Phytologist 54, 255-256.

Jarvis, D.I., Leopold, E.B., Liu, Y., 1992. Distinguishing the pollen of deciduous oaks, evergreen oaks and certain rosaceous species of southwestern Sichuan Province, China. Review of Palaeobotany and Palynology 75, 259-271.

Jones, J.H., 1986. Evolution of the Fagaceae: The implications of foliar features. Annals of the Missouri Botanical Garden 73, 228-275.

Kosmath, L., 1927. Studie über das Antherentapetum. Österreichische Botanische Zeitschrift 76, 235-241.

Kremer, A., Abbott, A.G., Carlson, J.E., Manos, P.S., Plomion, C., Sisco, P., Staton, M.E., Ueno, S., Vendramin, G.G., 2012. Genomics of Fagaceae. Tree Genetics \& Genomes 8, 583-610.

Kubitzki, K., 1993. Fagaceae. In: Kubitzki, K. (ed.), The families and genera of vascular plants, 2. Springer, Berlin, Heidelberg, New York, pp. 301-309.

Kuprianova, L.A., 1965. Palinologiya serezhkotsvetnikh (Palynology of Amentiferae). Nauka, Moscow, Leningrad (in Russian).

Kuprianova, L.A., Alyoshina, L.A., 1967. Palinologicheskaya terminologiya pokritosemennikh rasteni. Nauka, Leningrad (in Russian).

Kuprianova, L.A., Alyoshina, L.A., 1972. Pyl'tsa i spory rasteni flori Yevropeyskoy chasti SSSR (Pollen and spores of plants of the flora of the European part of USSR), I. Akademiya Nauk SSSR, BIN, Leningrad (in Russian).

Litt, T., Pickarski, N., Heumann, G., Stockhecke, M., Tzedakis, P.C., 2014. A 600,000 year long continental pollen record from Lake Van, eastern Anatolia (Turkey). Quaternary Science Reviews 104, 30-41.

Liu, Y.S., Zetter, R., Ferguson, D.K., Mohr, B.A.R., 2007. Discriminating fossil evergreen and deciduous Quercus pollen: a case study from the Miocene of Eastern China. Review of Palaeobotany and Palynology 145, 289-303.

Makino, M., Hayashi, R., Takahara, H., 2009. Pollen morphology of the genus Quercus by scanning electron microscope. Scientific Reports of Kyoto Prefectural University, Life and Environmental Sciences 61, 53-81.

Manos, P.S., Zhou, Z.K., Cannon, C.H., 2001. Systematics of Fagaceae: phylogenetic tests of reproductive trait evolution. International Journal of Plant Sciences 162, 1361-1379.

Marquez, J., Seoane-Camba, J., Suarez-Cervera, M., 1997. The role of the intine and cytoplasm in the activation and germination processes of Poaceae pollen grains. Grana 36, 328-342.

Meduz, J., Gonzales Flores, G., 1984. Pollen morphology of some Mexican oaks. Grana 23, 77-84.

Meinke, H., 1927. Atlas und Bestimmungsschlüssel zur Pollenanalyse. Bot. Archiv. 19, 380-449.

Menitsky, Y.L., 1980. Fagaceae. In: Zhizn' rasteni, 5(1). Prosveshchenie, Moskva, pp. 293-311 (in Russian).

Menitsky, Y.L., 1982. Obzor vidov roda Quercus L. Yevrazii (Conspectus specierum generis Quercus L. Gerontogeae). Nauka, Leningrad (in Russian).

Menitsky, Y.L., 1984. Duby Asii. Nauka, Leningrad (in Russian).

Menitsky, Y.L., 2005. Oaks of Asia. Science Publishers, Enfield, USA.

Menitsky, Y.L., 2012. Fagaceae Dumort. In: Kudryashova, G.L., Tatanov, I.V. (eds), Konspekt flory Kavkaza (Caucasian flora conspectus), 3(2). Association of Scientific Publications KMK, St. Petersburg, Moscow, pp. 286-292 (in Russian). https:// www.binran.ru/resursy/informatsionnyye-resursy/ tekuschie-proekty/caucasian-flora/contentkav/ allpdf/tom32.php

Meyer, N.R., 1980. Veroyatnie napravleniya evolyutsii sporodermy golosemennikh i nekotorikh pokrytosemennihh. In: Sistematika i evolyutsiya vishikh rasteni. Nauka, Leningrad, pp. 86-92 (in Russian).

Monoszon, M., 1954. Morfologicheskoe opisanie pil'tsi glavneyshikh vidov duba, proizrastayushchikh na territorii SSSR. Trudi Instituta geografii AN SSSR 61, 93-118 (in Russian).

Monoszon, M., 1961. O variatsiyakh morfologicheskikh priznakov pil'tsi nekotorikh vidov duba. Dokladi Academii Nauk SSSR 140(6), 1456-1459 (in Russian).

Mühlenthaler, K., 1955. Die Struktur einiger Pollenmembranen. Planta 46(1), 1-13.

Mulkidzhanyan, YA.I., 1962. Fagaceae. Flora Armenii, 4. Akademiya Nauk ArmSSR, Yerevan, pp. 374391 (in Russian).

Nakagava, T., Yasuda, Y., Tabata, H., 1996. Pollen morphology of Himalayan Pinus and Quercus and its importance in palynological studies in Himalayan area. Review of Palaeobotany and Palynology 91(14), 317-329.

Naryshkina, N.N., 2013. Morfologia sovremennoy i iskopaemoy pil'tsi nekotorikh vidov roda Quercus L. Synopsis of master's thesis. Biologo-pochvenni institut DVO RAN, Vladivostok (in Russian). 
Olsson, U., 1975. A morphological analysis of phenotypes in populations of Quercus (Fagaceae) in Sweden. Botaniska Notiser 128, 55-68.

Pacini, E., Franchi, G.G., Hesse, M., 1985. The tapetum: its form, function and possible phylogeny in embryophyta. Plant Systematics and Evolution 149, 155-185.

Panahi, P., Pourmajidian, M.R., Fallah, A., Pourhashemi, M., 2012. Pollen morphology of Quercus (subgenus Quercus, section Quercus) in Iran and its systematic implication. Acta Societatis Botanicorum Poloniae 81, 33-41.

Papini, A., Simeone, M.C., Bellarosa, R., Spada, F., Schirone, B., 2011. Quercus macranthera Fisch. \& Mey. ex Hohen. and Quercus iberica M. Bieb. Taxonomic definition and systematic relationships with European oaks inferred from nuclear internal transcribed spacer (ITS) data. Plant Biosystems 145(1), 37-49.

Pilcher, J.R., 1968. Some application of scanning electron microscopy to the study of modern and fossil pollen. Ulster Journal of Archeology (UJA) 31, 87-91.

Potonié, R., 1934. Zur Morphologie der fossilen Pollen und Sporen. Arbeiten des Instituts für Paläobotanik und Petrographie der Brennsteine 4, 5-24.

Praglowski, J., 1982. Fagaceae L.: Fagoideae. World pollen and spore flora, 11. Almqvist \& Wiksell, Stockholm.

Punt, W., Hoen, P.P., Blackmore, S., Nilsson, S., Le Thomas, A., 2007. Glossary of pollen and spore terminology. Review of Palaeobotany and Palynology 143, 1-81.

Rowley, J.R., Gabaraeva, N.I., 2004. Microspore development in Quercus robur (Fagaceae). Review of Palaeobotany and Palynology 132, 115-132.

Sadori, L., Koutsodendris, A., Panagiotopoulos, K., Masi, A., Bertini, A., Combourieu-Nebout, N., Francke, A., Kouli, K., Joannin, S., Mercuri, A.M., Peyron, O., Torri, P., Wagner, B., Zanchetta, G., Sinopoli, G., Donders, T.H., 2016. Pollen-based paleoenvironmental and paleoclimatic change at Lake Ohrid (south-eastern Europe) during the past $500 \mathrm{ka}$. Biogeosciences 13, 1423-1437.

Samoilovich, S., 1950. Rod Quercus L. - Dub. In: Krishtofovich, A.N. (ed.), Pil'tsevoy analiz. Gosgeolizdat, Moskva, 226-231 (in Russian).

Schottky, E., 1912. Die Eichen des extratropischen Ostasiens und ihre pflanzengeographische Bedeutung. Botanische Jahrbücher für Systematik 47, 617-708.

Schwarz, O., 1936a. Über die Typologie des Eichenblattes und ihre Anwendung in der Paläobotanik. Feddes Repertorium 86(13), 60-70.

Schwarz, O., 1936b-1939. Monographie der Eichen Europas und des Mittelmeergebietes. Repertorium specierum novarum regni vegetabilis, Sonderbeiheft D, I(1-5), II(1-4). F. Fedde, Berlin.
Schwarz, O., 1964. Quercus L. In: Tutin, T.G., Heywood, V.H., Burges, N.A., Valentine, D.H., Walters, S.M., Webb, D.A. (eds), Flora Europaea, vol. 1: Lycopodiaceae to Platanaceae. Cambridge University Press, Cambridge, pp. 61-64.

Shtepa, I.S., 1942. Stroenie pol'tsi kavkazskikh predstaviteley sem. Fagaceae Soobshcheniya Akademii Nauk Gruzinskoy SSR 3(5), 451-457 (in Russian).

Smit, A., 1973. A scanning electron microscopical study of the pollen morphology in the genus Quercus. Acta Botanica Neerlandica 22(6), 655-665.

Smolyaninova, L.A., Golubkova, V.F., 1950. K metodike issledovaniya pil'tsi. Dokladi Akademii Nauk SSSR 75(1), 125-126 (in Russian).

Solomon, A.M., 1983a. Pollen morphology and plant taxonomy of white oaks in eastern North America. American Journal of Botany 70(4), 481-494.

Solomon, A.M., 1983b. Pollen morphology and plant taxonomy of red oaks in eastern North America. American Journal of Botany 70(4), 495-507.

Sporne, K.R., 1973. A note on the evolutionary status of tapetal types in dicotyledons. New Phytologist $72,1173-1174$.

Takhtajan, A.L., 1966. Sistema i filogeniya tsvekovikh rasteni (Systema et Phylogenia Magnoliophytorum). Nauka, Moskva, Leningrad (in Russian).

Takhtajan, A., 1987. Sistema Magnoliofitov (Systema Magnoliophytorum). Nauka, Leningrad (in Russian).

Takhtajan, A., 1997. Diversity and classification of flowering plants. Columbia University Press, New York.

Takhtajan, A., 2009. Flowering Plants. Springer, Netherlands.

Tekleva, M.V., 2012. Skritoe raznoobrazie, ili elektronni mikroskop speshit na pomoshch (Reports of popular science articles of winners of The Russian Foundation for Basic Research of 2012 competition). Biologia i meditsinskie nauki. ITZC Molnet, pp. 158-167 (in Russian).

Tekleva, M.V., Polevova, S.V., 2014. Morfologia i ul'trastruktura sporodermi v sistematike roda Quercus L. Semicentenary after Konstantin Meyer: XIII Moskow Symposium on plant phylogeny, Moskva, Rossia (2-6 February 2015), 295-299 (in Russian).

The Plant List. http://www.theplantlist.org/

Trelease, W., 1924. The American oaks. Memoirs of the National Academy of Sciences 20, 1-255.

Tzedakis, P.C., Hooghiemstra, H., Pälike, H., 2006. The last 1.35 million years at Tenaghi Philippon: revised chronostratigraphy and long-term vegetation trends. Quaternary Science Reviews 25, 3416-3430.

Valdes, B., Diez, M.J., Fernandez, I., 1987. Atlas Polinico de Andalucia Occidental. Instituto de Dessarrollo Regional N 43, Universidad de Sevilla, Sevilla, Spain.

Van Benthem, F., Clarke, G.C.S., Punt, W., 1984. Fagaceae. Review of Palaeobotany and Palynology 42, 87-110. 
Wang, P.L., Chang, K.T., 1991. The pollen morphology in relation to the taxonomy and phylogeny of Fagaceae. Acta Phytotaxonomica Sinica 29, 60-66.

Wang, P.L., Pu, F.T., Zheng, Z.H., 2000. Pollen morphology of the genus Nothofagus and its taxonomic significance. Acta Phytotaxonomica Sinica 38, 452-461.

Wodehouse, R.P., 1935. Pollen grains. McGraw-Hill, New York, London.

Wodehouse, R.P., 1936. Evolution of pollen grains. The Botanical Review 2, 67-84.

Wronska-Pilarek, D., Danielewicz, W., Bocianowski, J., Malinski, T., Janyszek, M., 2016. Comparative pollen morphological analysis and its systematic implications on three european Oak (Quercus L.,
Fagaceae) species and their spontaneous hybrids. PLOSone 11(8), 1-19.

Xiang, X.-G., Wang, W., Li, R.-Q., Lin, L., Liu, Y., Zhou, Z.-K., Li, Z.-Y., Chen, Z.-D., 2014. Largescale phylogenetic analyses reveal fagalean diversification promoted by the interplay of diaspores and environments in the Paleogene. Perspectives in Plant Ecology, Evolution and Systematics 16(3), 101-110.

Xing, Y.-W., Hu, J.-J., Jacques, F.M.B., Wang, L., Su, T., Huang, Y.-J., Liu, Y.-S., Zhou, Z.-K., 2013. A new Quercus species from the upper Miocene of southwestern China and its ecological significance. Review of Palaeobotany and Palynology 193, 99-109. 